\title{
A COLETA A GRANEL DE LEITE REFRIGERADO E SUAS IMPLICAÇÕES SOBRE AS RELAÇÕES CONTRATUAIS ENTRE PRODUTOR E INDÚSTRIA: UM ESTUDO DE CASO
}

\section{STIVILANE DORNELAS}

Economista

\author{
Orientador: Prof. Dr. MARCOS SAWAYA JANK
}

\author{
Dissertação apresentada à Escola Superior de \\ Agricultura "Luiz de Queiroz", Universidade de \\ São Paulo, para obtenção do título de Mestre \\ em Ciências, Área de Concentração: Economia \\ Aplicada. \\ PIRACICABA \\ Estado de São Paulo - Brasil \\ Janeiro - 2000
}


Dados Internacionais de Catalogação na Publicação (CIP)

DIVISÃO DE BIBLIOTECA E DOCUMENTAÇÃO - Campus "Luiz de Queiroz"/USP

\section{Dornelas, Stivilane}

A coleta a granel de leite refrigerado e suas implicaçōes sobre as relaçōes contratuais entre produtor e indúntria: um estudo de caso / Stivilane Dornelas. - Piracicaba, 2000.

$130 \mathrm{p}$.

Dissertação (mestrado) - - Escola Superior de Agricultura Luiz de Queiroz, 2000. Bibliografia.

1. Comercialização agrícola 2. Economia agricola 3. Indústria de laticínio 4. Leite refrigerado 5 . Produtor rural 6 . Transporte rural I. Título

CDD 338.1771

"Permitida a cópia total ou parcial deste documento, desde que cifada a fonte $-\mathbf{O}$ autor" 


\section{AGRADECIMENTOS}

À minha mãe, que sempre acreditou em mim e me apoiou em toda minha formação educacional.

Ao Júnior, em quem encontrei o amor e a paz de que tanto precisei para a finalização do trabalho.

Ao amigo Joni, pelas informações prestadas e o constante apoio.

Aos Senhores Leonardo Vilela (Sec. Agricultura de Goiás), Vicente N. Neto (CNA), Márcio Carvalho (FAEMG), Antônio Carlos e Dario (Nestlé) pelo apoio na pesquisa de campo.

A todos os colegas do Departamento de Economia e Sociologia Rural da ESALQ, pela amizade e colaboração em todas as fases do meu programa de mestrado. Agradeço especialmente ao Alexandre Mendonça pela acolhida nos primeiros dias em Piracicaba.

Aos amigos Ignez e Mauro Lopes pela recepção e oportunidade de iniciação na carreira profissional. Agradeço também aos colegas do Centro de Estudos Agrícolas da Fundação Getúlio Vargas: Gregory, Viviane, Guilherme, Caíque, Irene e especialmente à Daniela, pela amizade e constante estímulo.

Ao meu orientador Prof. Marcos Jank, pela orientação, paciência e motivação na formalização do meu estudo. Aos professores Carlos J. Bacha e José V. Caixeta, cujas contribuições no seminário e na qualificação foram muito úteis para a concretização do projeto.

À Coordenação de Aperfeiçoamento de Pessoal de Nivel Superior (CAPES$M E C)$, pelo apoio financeiro.

À Maielli, que, sempre simpática e solícita, nos atendeu prontamente nos encaminhamentos burocráticos do curso.

E acima de tudo, agradeço a Deus, pela vida, sabedoria e iluminação permanente em meu caminho. 


\section{SUMÁRIO}

1. INTRODUÇÃO

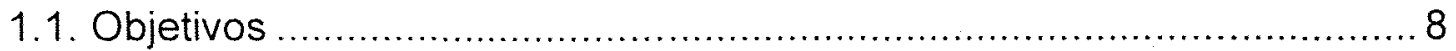

1.2. Hipótese da pesquisa ..................................................................... 8

1.3. Contextualização e problemática do estudo ......................................... 9

1.4. Revisão de Literatura .......................................................................... 15

1.5. Estrutura do trabalho ...................................................................... 17

2.REFERENCIAL TEÓRICO: ................................................................. 19

2.1. A Economia dos Custos de Transação .............................................19

2.2. Transaçōes, Contratos e Estruturas de Governança ……………........2 23

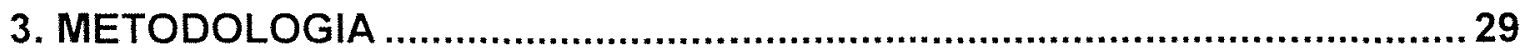

3.1.Caracterização da pesquisa e coleta de dados ………………..............2 29

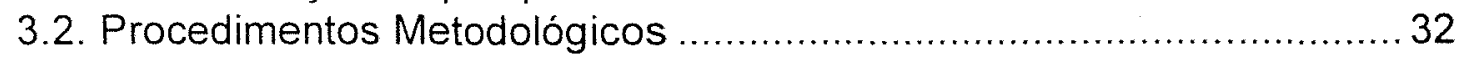

4. A COLETA A GRANEL NO BRASIL E NO MUNDO ……..............................

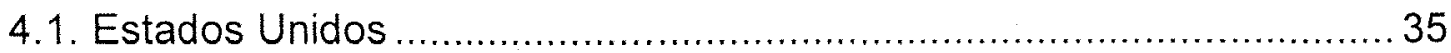

4.2. Reino Unido e Nova Zelândia ............................................................. 39

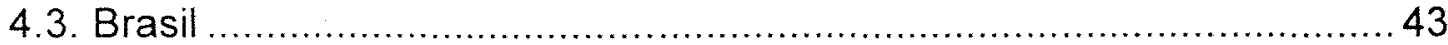

5. QUALIDADE DO LEITE NO BRASIL E NO MUNDO.................................... 48

6. A COLETA A GRANEL E AS RELAÇÕES PRODUTOR/INDÚSTRIA ........73

6.1. Avaliação quantitativa da granelização da coleta de leite....................73

6.2. Avaliação qualitativa da granelização da coleta de leite ......................8 81

6.2.1. Sobre as relações entre produtor e indústria ................................. 82

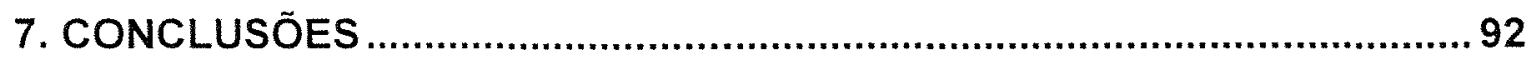

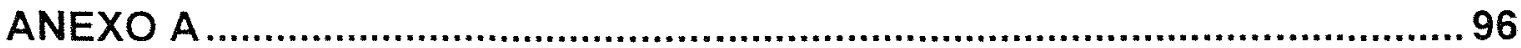

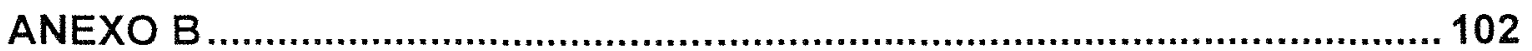

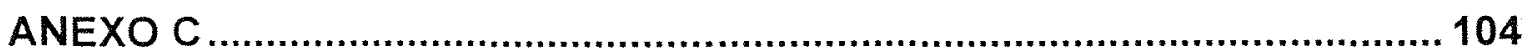

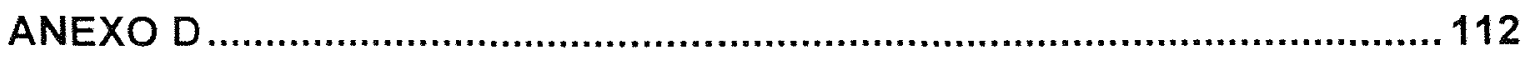

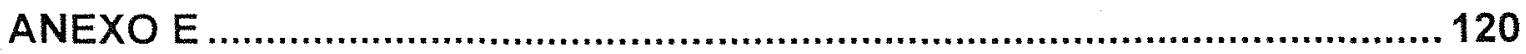

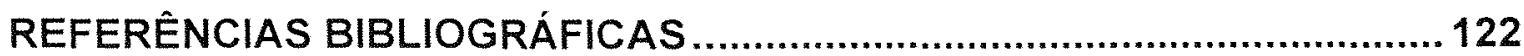




\section{A COLETA A GRANEL DE LEITE REFRIGERADO E SUAS IMPLICAÇÕES SOBRE AS RELAÇÕES CONTRATUAIS ENTRE PRODUTOR E INDÚSTRIA: UM ESTUDO}

Autora: STIVILANE DORNELAS Orientador: Prof. Dr. MARCOS SAWAYA JANK

\section{RESUMO}

Este estudo tem a finalidade de investigar como a modificação na estrutura de captação e transporte do leite provocou mudanças nas relações entre um grupo de produtores e uma determinada indústria de laticínios na região Sudoeste de Minas Gerais.

A pesquisa busca responder que tipo de relação será desenvolvida entre produtor e indústria diante das modificações impostas pelo resfriamento do leite na propriedade rural e a granelização da coleta do mesmo. A proposta deste estudo é discutir qual será a forma organizacional dominante nestas relações segundo critérios minimizadores de custos de transação e de ganhos em eficiência produtiva. 


\title{
THE BULK MILK COLLECTION SYSTEM AND ITS IMPLICATIONS ON THE CONTRACTUAL RELATIONSHIPS BETWEEN DAIRY FARMERS AND DAIRY COMPANIES: A CASE STUDY
}

\author{
Autor: STIVILANE DORNELAS \\ Advisor: Prof. Dr. MARCOS SAWAYA JANK
}

\section{SUMMARY}

The purpose of this study is to investigate how changes in the collection and transportation of milk has altered the relationships between a group of producers and a dairy company in the southwest region of Minas Gerais. What type of relationship will be developed between milk producers and the dairy after these changes? What will be the dominant contractual set up according the criteria of minimizing transaction costs and maximizing productive efficiency? 


\section{INTRODUÇÃO}

A finalidade desta pesquisa é conhecer e elucidar algumas mudanças por que passa o setor leiteiro diante da intensificação do processo de coleta a granel de leite refrigerado, com avanço progressivo em quase todas as regiões brasileiras, bem como investigar os impactos que tais mudanças poderiam determinar nas relações entre produtor e processador de leite na região Sudoeste de Minas Gerais.

A coleta a granel de leite refrigerado é um processo que envolve a captação de leite frio e a granel, nas fazendas, por meio de um caminhão adaptado com tanque frigorificado. Trata-se de uma revolução nos moldes de produção e de comercialização da matéria-prima leite. Por meio de um controle maior da sanidade do rebanho nas fazendas $e$ análises de qualidade laboratoriais do leite na plataforma industrial, o processo representa um fator propulsor da modernização da pecuária leiteira nacional.

Este processo foi desencadeado a partir do acirramento da concorrência instaurada no País nos anos 90 . Com a desregulamentação no mercado de leite ocorrida em 1991 e a abertura comercial consolidada, principalmente após o advento do Mercosul, a competitividade do setor de lácteos foi remetida aos critérios de qualidade, redução de custos e ganhos em produtividade. As empresas laticinistas, atentas a tais critérios, alavancaram mudanças na operação da coleta de leite, ampliando seus investimentos em caminhões especializados e em tanques de resfriamento nas propriedades rurais para a coleta a granel do leite refrigerado. Esta operação, além de promover uma 
racionalização da coleta, tem propiciado um maior comprometimento entre as partes envolvidas na transação.

Este processo trouxe à tona a hipótese de que novos vínculos e especificidades deveriam surgir nas relações entre produtor e indústria, criando canais redutores de custos nas suas transações, fidelidade e ganhos para ambas as partes.

\subsection{Objetivos}

- O objetivo principal deste trabalho é identificar as possiveis mudanças que as exigências de qualidade trazidas com o processo de coleta a granel de leite estão determinando sobre as relações contratuais entre os agentes dos segmentos de produção e processamento na região Sudoeste de Minas Gerais, a partir do estudo de caso de uma empresa laticinista de grande relevância na região.

- Como objetivo secundário, o trabalho busca analisar as mudanças estruturais que ocorreram na economia leiteira de alguns paises, dentre eles o Brasil, em decorrência da evolução dos sistemas de controle da qualidade do leite e da granelização de sua coleta. Pretende-se também descrever as iniciativas públicas e privadas tomadas no Brasil quanto à revisão das normas de qualidade na produção e no processamento de leite e derivados.

\subsection{Hipótese da pesquisa}

O processo de granelização da coleta de leite refrigerado estimulará o aumento do grau de fidelidade entre produtor e indústria, motivando mudanças e maior interdependência na relação entre estes agentes. A hipótese deste trabalho afirma que este processo favorecerá o desenvolvimento de novas formas de governança entre as duas partes envolvidas, em função do aumento 
das especificidades da matéria-prima leite.

\subsection{Contextualização e problemática do estudo}

A produção e a comercialização de leite e derivados têm tido importante papel em Paises em desenvolvimento. Neste sentido, o sistema de coleta de leite deve atender aos predicados próprios de cada estrutura regional, de forma que ele seja o mais eficiente possível na busca pela qualidade do leite, facilidade de transporte e conveniência no fornecimento, seja aos consumidores regionais ou à indústria.

Como o leite é um produto comercializado desde civilizações milenares, seu processo de coleta foi sendo modificado no decorrer dos anos em função das necessidades surgidas e restrito às condições propícias. Em lombo de burros, em carroças ou em caminhonetes ambulantes, o leite foi sendo transportado nos mais variados percursos rurais.

A partir do século $X X$, o sistema de coleta de leite passou por uma revolução nos principais Países de pecuária leiteira desenvolvida, tais como Nova Zelândia, Austrália, Estados Unidos e Europa. Nestes Países, a coleta a granel representou um marco na modernização da pecuária leiteira não somente na captação de leite, mas também nos moldes de produção, na seleção de produtores mais eficientes e em ganhos em competitividade para o setor.

No Brasil, o processo começou a tomar forma em alguns estados de forma isolada. Destacou-se, inicialmente, o estado do Rio Grande do Sul, onde, hoje, $100 \%$ da coleta de leite já está granelizada. Minas Gerais, Goiás e São Paulo são outros estados que avançam progressivamente neste processo.

Ainda que planejado com o fim de atender às necessidades imediatas de eficiência produtiva e economias de custos com transporte, o sistema de coleta de leite a granel teve repercussões sobre o meio ambiente. Seja através de 
programas de limpeza e de canalização de restos de leite que escoam dos laticínios e ou de postos de resfriamento; seja por meio da pavimentação de estradas rurais, ou ainda, propiciando a humanização do trabalho nas fazendas. O processo tem estimulado ações sociais e políticas que beneficiam as comunidades rural e urbana.

A coleta a granel é um processo relativamente novo no Brasil. $O$ atraso na sua efetivação se deve a basicamente dois fatores: o controle do governo sobre o preço do leite, um fator que impedia a concorrência, e a inflação alta e desenfreada, que desestimulava investimentos e laços de maior fidelidade. Nos anos 90 - quando até então a variável de decisão era única e exclusivamente o preço - esses dois fatores foram removidos e a produção brasileira de leite entrou numa nova fase, mais voltada aos parâmetros de eficiência.

Sob este prisma, a crescente concorrência com o setor externo sobrepôs-se aos termos de capacidade tecnológica operacional do setor e aumentou o apelo ao segmento produtivo por qualidade e redução de custos, tanto por ganhos em escala como em produtividade (Meireles, 1997).

Os programas para monitoramento da qualidade do leite, que foram estabelecidos, historicamente, com a finalidade de proteger a saúde foram redirecionados (Meireles, 1996). Com o paradigma da coleta a granel de leite frio, eles passaram a cumprir e atender critérios econômicos e de competitividade, principalmente para a indústria, que passou a funcionar como um elo de ligação entre a produção de leite e o mercado consumidor (Almeida e Silva, 1997) ${ }^{1}$.

Os aspectos de qualidade que envolvem a coleta a granel dizem respeito ao resfriamento do leite nas fazendas - embora seja igualmente importante os cuidados com higiene, manejo e dieta do gado - bem como dispor de boas instalações de processamento nos postos de beneficiamento do produto

\footnotetext{
Ver anexo A sobre aspectos físico-químicos. microbiológicos e sanitários de qualidade do leite.
} 
(Santos, 1997). É a refrigeração ${ }^{2}$ que garante a conservação da qualidade do leite, evita a multiplicação de colônias de bactérias no produto, bem como evita sua acidez, reduzindo perdas do produtor com leite contaminado, e permitindo melhor rendimento industrial (Rentero, 1997).

Igualmente importante neste processo de modernização da pecuária leiteira é o transporte de leite frio e a granel. Seu grande potencial está em reduzir os custos do primeiro percurso, já que possibilita realizar a coleta em dias alternados, permitindo inclusive, ao produtor, a possibilidade de duas ordenhas por dia, segundo o horário de sua conveniência. E devido à independência de horários, permite racionalizar de forma mais eficiente a linha de coleta, e portanto, menor número de caminhões transitando nas estradas.

A coleta a granel elimina o papel intermediador de alguns postos de recepção do leite, possibilitando o transporte direto das propriedades rurais às plataformas de processamento. Este transporte dispensa o uso de latões, que ocupam espaço e são dificeis de limpar; evita a exposição do leite ao sol e à poeira; e reduz a exigência de mão de obra, com o leite indo direto do local de ordenha para o tanque de resfriamento.

Pesquisas recentes revelam que, no que diz respeito aos custos de produção, em especial os operacionais, os custos de frete no primeiro percurso representam entre 4 e $25 \%$ do preço do leite recebido pelo produtor, chegando, em algumas regiões do pais, a $40 \%$. Essa diferença é basicamente determinada pela baixa densidade de produção, que é medida pela relação do volume de leite transportado com a quantidade de quilômetros percorridos pelo veículo, das fazendas às plataformas de recepção (Ferreira Sobrinho et al., 1995).

O processo, embora exija altos investimentos iniciais em refrigeradores

\footnotetext{
${ }^{2}$ A importância da refrigeração está em impedir que bactérias e enzimas se multipliquem rapidamente. A temperatura ideal para estocagem e transporte do leite é de 3 a $4{ }^{\circ} \mathrm{C}$, devendo ser reduzido para este nivel a temperatura do leite ordenhado, que é de 35 a $36 \circ \mathrm{C}$, no periodo de duas a duas horas e meia, no máximo (Laranja, 1996).
} 
resfriadores, a negociação complicada com os carreteiros (problemas judiciais), e principalmente, a resistência do produtor à mudança (Rentero, 1997).

Não obstante tais fatores, supõe-se que a restruturação do sistema leite, a seleção natural dos produtores mais capacitados, o estabelecimento de vinculos mais fortes entre os segmentos de produção e processamento, tendem a propiciar novas relações contratuais entre produtor e indústria (Jank, 1997b).

A restruturação deste sistema envolve a redefinição das transações entre os segmentos de produção e processamento na comercialização do leite e derivados, já que o encadeamento de informações do consumidor e o estímulo à produção passam a determinar um novo modelo de coordenação para o setor.

A seleção natural dos produtores criou um novo desafio, principalmente, para as cooperativas: a disputa por produtores com maiores escalas. Segundo Farina (1996a),

"preservar seus grandes cooperados para viabilizar a sobrevivência de um grande número de pequenos $e$, ao mesmo tempo, competir no mercado de produto tem se tornado uma das grandes ameaças às cooperativas, especialmente às de menor porte e menor capacidade financeira".

Este desafio também afeta as centrais, devido à vulnerabilidade que suas associadas são expostas. O conflito gerado no sistema, rompendo práticas de negociação reconhecidas pelas partes e criando dificuldades para adaptações a novos tempos, despertou as centrais, principalmente aquelas mais próximas dos mercados mais dinâmicos, exigentes e competitivos, para a questão de escala e qualidade. Assim, os novos sistemas de pagamento passaram, então, a ser adotados segundo essas exigências.

O pagamento por qualidade, além de transmitir um incentivo claro ao estabelecimento de padrōes de higiene, também viabiliza a diferenciação dos 
produtores por escala, o que é fundamental para preservar os fornecedores mais disputados pelas indústrias privadas que não têm compromisso com os cooperados (Farina, 1996b).

Neste sentido, os vinculos criados com a operação de coleta a granel dizem respeito às especificidades auto-geradas com o processo tanto para o produtor como para a indústria. Entre estas citam-se: sistemas de bonificação por qualidade da matéria-prima; regularidade na entrega do leite, o que diminui incertezas para a indústria e aumenta a renda para o produtor; e ganhos em escala de produção por produtor ou por condominio de produtores, o que racionaliza a coleta e reduz os custos com fretes para a indústria (Jardim, 1996).

O pioneirismo de ação de algumas empresas neste processo proporciona a chance de selecionar os melhores fornecedores, ainda que seja claro que a disputa pelos produtores mais eficientes (maior produção e maior produtividade) tenha conseqüências danosas e excludentes para os menos aptos.

Assim, o problema que norteou este estudo foi identificar que tipo de produtor permanecerá no mercado de leite e como se estabelecerão suas relações com a indústria diante da intensificação ${ }^{4}$ do processo de coleta a granel de leite refrigerado e o estabelecimento de maiores especificidades nas transações entre estes agentes.

Hoje em dia, embora existam modelos de contratos ${ }^{5}$ entre produtor de leite e laticinista, a contratação é feita, via de regra, de forma verbal e as partes pouco se comprometem. Tanto ao produtor quanto à indústria interessa o preço do produto envolvido na transação, com cada um dos agentes buscando

4 Diz-se intensificação porque o processo não é novidade. Algumas empresas já o utilizam há muito tempo, como a Batavo, desde 1950, e a CCGL (Cooperativa Central Gaúcha de Laticínios, atualmente pertencente à empresa Avipal), que iniciou o processo em 1980 e hoje conta com $100 \%$ de sua coleta feita a granel. Entretanto, a incrementação nos investimentos e operacionalização do processo se intensificaram na maioria das regiöes brasileiras a partir de 1995.

5 Ver um típico modelo de contrato no anexo $B$. 
isoladamente seus próprios ganhos. A granelização representa, neste contexto, a possibilidade de um novo arranjo institucional, ditando novas regras para a coordenação do setor.

Diante deste quadro, este estudo se justifica pela presente necessidade em se conhecer o novo paradigma econômico que se estabeleceu no setor leiteiro com a chamada "coleta a granel". O processo vem ganhando forma e estruturando-se como um marco de especialização e desenvolvimento deste setor no Brasil. Neste cenário a indústria é a principal protagonista das mudanças, modernizando e alterando as relações entre ela e o produtor (Jank, 1997a).

\subsection{Revisão de Literatura}

Recentemente, o tema "coleta a granel de leite refrigerado" tem tomado espaço nos mais variados meios de notícia sobre o setor agrícola, sejam as revistas especializadas (Balde Branco, DBO, Leite Brasil, Globo Rural, Indústria de Laticínios, Batavo, entre outras), os jornais (Folha de São Paulo Agrofolha, O Estado de São Paulo - Suplemento Agricola) ou os programas de televisão (Globo Rural).

No meio acadêmico, os estudos sobre coleta de leite e seus aspectos, como custos de frete, racionalização de linhas de coleta e implicações sobre as relações entre os segmentos de produção e processamento, no Brasil, ainda são incipientes, embora sejam significativos em termos de contribuições empíricas regionais.

A preocupação, principalmente com custos de transporte, tem tomado conta dos principais estudos que envolvem a coleta de leite. Quando ainda nem se cogitava o projeto de coleta a granel de leite refrigerado na Zona da Mata, precisamente no município de Viçosa - Mg, Soares (1988) desenvolveu um modelo sobre reorganização eficiente de rotas para a coleta de leite nesta 
região. Silva (1999), em estudo semelhante, desenvolveu um modelo de programação linear baseado em minimização de custos de transporte para linhas de coleta de leite a granel na região de Lavras - MG.

Ambos estudos cercam-se de uma análise computacional sobre programação linear e racionalização de percursos visando economias nos custos com frete - combustivel, manutenção, desgaste, reparos, salário do carreteiro, etc. - que envolvem os sistemas de coleta de leite, sejam em latões ou a granel.

Soares (1996) desenvolveu um estudo focando os contratos entre produtor e indústria na coleta a granel de leite refrigerado no Reino Unido. Este autor investigou as alterações que a desregulamentação no mercado de leite provocou nos termos do contrato entre as referidas partes e como a operação de coleta a granel propiciou redução de custos através de um planejamento de logística, comunicação, roteamento das linhas de coleta, entre outros.

Nesta mesma linha tem-se o estudo de Calegário (1996), onde foram analisadas as relações contratuais entre produtor e indústria de leite na região de Lavras, Minas Gerais. Além de identificar os principais conflitos existentes nestas relações, este trabalho traz um levantamento sobre os benefícios mútuos que um possivel arranjo contratual formalizado propiciaria às partes.

Como se pode observar, estes quatro estudos retrataram, de forma diferente, os impactos que uma mudança no processo produtivo ou comercial têm sobre a organização econômica dos agentes que estão envolvidos, bem como as economias externas dai derivadas.

Nessa mesma perspectiva, porém centrado numa análise mais qualitativa, o presente estudo foca sua atenção nos segmentos produçãoprocessamento e difere dos dois últimos trabalhos citados quanto à forma de aplicação teórica para a análise das transações de compra e venda de leite entre indústria e produtor na região Sudoeste de Minas Gerais.

Sem a pretensão de descrever as relações entre os agentes produtivos 
ao longo do sistema agro-industrial do leite, ou de quantificar as economias em custos com frete e qual a quilometragem economicamente viável, a presente pesquisa busca retratar como as relações entre produtor e indústria se comportavam antes e como tendem a se comportar após a granelização da coleta de leite frio.

\subsection{Estrutura do trabalho}

O presente trabalho compõe-se de sete capítulos além desta Introdução, onde foram apresentados os objetivos, a hipótese e a problemática condutora da pesquisa.

No segundo capítulo está descrito o referencial teórico, que servirá de apoio às análises das relações contratuais em questão.

No terceiro capítulo são descritos a metodologia de abordagem do estudo, a caracterização da pesquisa, a coleta de dados, a amostragem e os procedimentos utilizados para a estruturação e análise dos resultados.

O quarto capitulo, cumprindo o objetivo secundário do estudo, apresenta uma descrição sobre o processo de intensificação da coleta a granel no Brasil, Estados Unidos, Reino Unido e Nova Zelândia e as respectivas transformações nos sistemas de comercialização de leite.

O quinto capítulo discorre sobre os critérios de pagamento por qualidade, relações contratuais e formas de fiscalização e controle do leite comercializado em vários Países do mundo, segundo o International Dairy Federation Bulletin. Este capitulo também atende ao objetivo secundário do presente estudo.

No sexto capitulo são relatados os resultados da pesquisa de campo, conforme proposto no objetivo central do estudo. Neste capitulo retratam-se as implicações que a modernização do sistema de captação de leite teve sobre as relações contratuais entre os produtores e uma determinada empresa de 
laticínios na região Sudoeste de Minas Gerais. Ao final deste capitulo retomase o problema inicial do estudo e discutem-se os resultados e a hipótese condutora do mesmo.

No sétimo capítulo, as conclusões abordam de forma resumida os objetivos do estudo, os resultados atingidos e traçam uma linha tendencial sobre as relações contratuais em estudo para o médio e longo prazos.

Nos anexos constam os materiais de apoio ao levantamento de dados na pesquisa de campo e informações adicionais sobre a produção e a comercialização de leite no Brasil. 


\section{REFERENCIAL TEÓRICO:}

\subsection{A Economia dos Custos de Transação}

A Economia dos Custos de Transação (ECT) forma parte da tradição de investigação da Nova Economia Institucional (NEI), cujos estudos começaram a surgir nos anos pós Segunda Guerra Mundial. Entretanto, o interesse nessa área se tornou crescente a partir do princípio dos anos $60^{6}$. A formulação de aplicações práticas da teoria começou a aparecer no princípio dos anos $70^{7}$, quando se passou a incorporar nas análises das relaçōes mercantis a importância que as instituições representavam sobre os ajustes eficientes daquelas (Williamson, 1985).

O novo institucionalismo surgiu como reação aos pressupostos neoclássicos que tratam a firma e o consumidor como agentes, e o mercado, como ambiente negocial, funcionando assim perfeitamente equilibrados por um ajuste automático de preços após um choque. Neste cenário estéril, as instituições são neutras e não se assume custos associados ao funcionamento da economia (Zylbersztajn, 1995).Comparativamente a outros enfoques do

\footnotetext{
${ }^{6}$ Entre as primeiras contribuições se encontra o novo conceito de Coase (1960) em relação aos custos sociais, o tratamento pioneiro dos direitos de propriedade feito por Alchian (1961), 0 trabalho de Arrow $(1962,1963)$ sobre os problemas da propriedade econômica da informação, e a contribuição de Chandler (1962) sobre a história empresarial.

${ }^{7}$ Incluem-se aqui os primeiros esforços de Williamson $(1971,1973)$ para reformular o problema da integração vertical em termos dos custos de transação e a tentativa de generalizar tal enfoque no contexto de mercados e hierarquias. São desse periodo também o trabalho de Alchian e Demsetz (1972) sobre a empresa capitalista clássica.
} 
estudo da organização econômica, a economia dos custos de transação é mais microanalítica. A ECT introduz e desenvolve a importância econômica da especificidade dos ativos, utiliza a análise institucional comparada, e considera a empresa como uma estrutura de governança e não uma mera função de produção, sendo mais realista em relação aos pressupostos comportamentais dos agentes. Nesse sentido, devota-se um apreço maior às instituições contratuais ex-post, com apoio especial no ordenamento privado, por oposição ao mecanismo legal centralizado (Siffert Filho, 1995).

O estudo das instituições econômicas, tal como analisa este autor, sustenta que a transação é a unidade básica de análise e o seu determinante é a forma da organização (firma ou hierárquica, mercado e mista) com o objetivo de minimização das somas dos custos de produção (neoclássica) e de transação (NEI).

Sob esta ótica, os custos de transação podem ser definidos como "os custos de selecionar, negociar e salvaguardar o acordo, bem como os custos de adaptação a eventuais falhas das condições contratuais, possiveis renegociações, e ainda os custos com o próprio monitoramento do cumprimento das cláusulas acertadas" (Williamson, 1985). Ou seja, são os custos necessários para conduzir o sistema econômico.

Dados os custos de transação, a estrutura de governança ${ }^{8}$ eficiente é delineada para as respectivas transaçōes econômicas. Cada transação conferida no funcionamento do sistema deve levar em consideração as caracteristicas da mesma (freqüência, incerteza e especificidade dos ativos envolvidos). A influência da freqüência com a qual a transação se realiza sobre a complexidade da relação contratual associada é relativamente óbvia, na medida em que dificilmente será economicamente justificável desenvolver

\footnotetext{
${ }^{8}$ A estrutura de governança é definida por Williamson (1985) como a matriz institucional na qual a transação é definida. Segundo este autor a distinção dos atributos das estruturas de governança se dá através de incentivos, controle e adaptação.
} 
instituições sofisticadas para interações que só ocorrem raramente, ou até mesmo em uma única oportunidade (Williamson, 1985).

O grau de incerteza, por sua vez, refere-se à maior ou menor confiança dos agentes na sua capacidade de antecipar acontecimentos futuros. Dificuldades em formular previsões confiáveis acerca do desenrolar dos acontecimentos econômicos levarão, por conseguinte, ao estabelecimento de relações contratuais que operacionalizem ajustes e negociações, reduzindo os custos de transação prospectivos. A incerteza associada às transações estimula os agentes a empreenderem ações que reduzam o impacto de eventos imprevisíveis sobre o seu desempenho, adotando, por exemplo, salvaguardas nos contratos.

Entretanto, se a relação for vista sob a questão do risco, verifica-se que ele aumenta independentemente do nivel de confiança envolvida entre os agentes, e muito em função da necessidade de investimentos específicos empregados na transação (Azevedo, 1996).

O último atributo vincula-se ao grau em que a transação exige "ativos específicos", ou seja, "ativos especializados que não podem ser reempregados sem sacrificio do seu valor produtivo se contratos tiverem que ser interrompidos ou encerrados prematuramente" (Williamson, 1985, p. 60). Sua presença faz com que a identidade dos participantes da transação, assim como a continuidade dos vinculos estabelecidos entre estes, ganhe uma dimensão econômica fundamental. As interações entre os agentes deixam de ser impessoais e instantâneas, o que acarreta custos para geri-las e conservá-las.

Segundo Williamson (1991), as especificidades dos ativos podem ser: dedicada (inversões em capital fixo especializado), física (expansão da capacidade produtiva direcionada para evitar ociosidade), locacional (proximidade geográfica entre as partes que transacionam), humana (aprendizado, ou treinamento, especifico para beneficio mútuo das partes), de marca (nicho de mercado), e temporal (diz respeito à perecibilidade do produto 
ou serviço transacionado).

Tomando uma análise estática comparativa, Williamson (1991) propõe um modelo analítico que relaciona o nível de especificidade dos ativos e os custos de governança. Para este autor, a decisão organizacional da empresa depende basicamente do grau de especificidade dos ativos envolvidos: a tendência à organização hierárquica cresce à medida que o grau de especificidade do ativo aumenta. Ou seja, quanto maior for a especificidade maior será o custo de monitoramento da transação via mercado. Esta relação pode ser visualizada na figura 1 , a seguir.

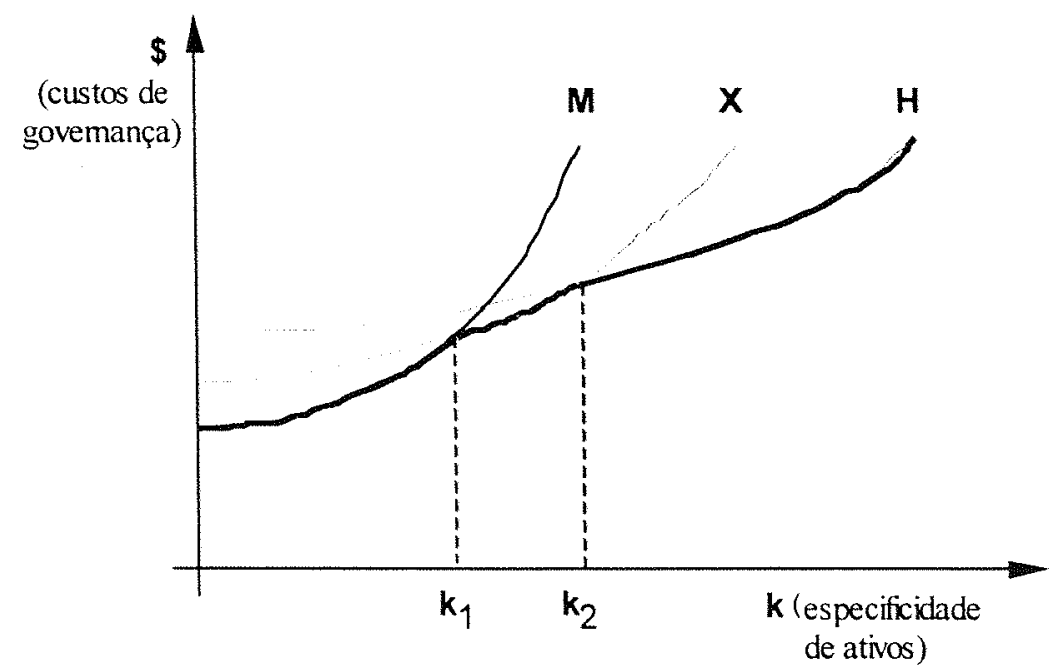

Legenda: $M=$ governança via mercado

$\mathrm{H}=$ governança via hierarquia

$X=$ governança via contratos (ou mista)

Figura 1: Custos e Estruturas de Governança

Nota-se que niveis baixos de especificidade dos ativos levam à preferência pela aquisição do produto no mercado $(M)$, enquanto niveis mais altos levam à decisão pela integração vertical $(H)^{9}$. Os pontos de eficiência das

\footnotetext{
"A presença de maior especificidade de ativos, maior nivel de risco ou incerteza e maior complexidade contratual leva à necessidade de proteção contra oportunismos e à definição de direitos, obrigações e procedimentos. Neste caso, o poder impositivo que existe na estrutura hierárquica da firma é preferivel à opção pelo mercado (Jank, 1996).
} 
transações concentram-se na curva em negrito envoltória na figura 1.

Zylbersztajn (1995, p. 137) sintetiza a proposição teórica considerando que as estruturas de governança prevalecentes são um resultado otimizador do alinhamento das caracteristicas das transações e do ambiente institucional.

Observando a caracterização de ativos especificos numa transação, pode-se afirmar que, de uma visão microeconômica, tal relação é uma situação muito próxima do que tradicionalmente é conhecido como monopólio bilateral, onde se formam laços de dependência mútua entre seus participantes e surge a necessidade de administrar uma contínua barganha, em cujo desenlace estão potencialmente emergentes tanto o conflito como a cooperação (Siffert Filho, 1995).

A recorrência das transações implica, então, em se criar interações apropriadas, nas quais existe um valor econômico vinculado à ligação das interfaces produtivas, de modo que proporcionem adaptabilidade e promovam a continuidade das relações entre os agentes. Consequentemente, é estimulado o desenvolvimento de salvaguardas contratuais e instituições que sustentem a integridade das transações. Tais instituições cumprem a função de diminuir a incerteza comportamental dos agentes - derivada do oportunismo elou diversidade cognitiva - e permitir reduções nos custos de adaptação e de ajuste das transações a novas circunstâncias. (Azevedo, 1996).

Assim, a realização de transações recorrentes que envolvam, em grau significativo, ativos específicos, estimulará o desenvolvimento de instituições que garantam sua continuidade e a efetivação dos eventuais ajustes necessários (Williamson, 1991).

\subsection{Transações, Contratos e Estruturas de Governança}

Na visão de Williamson (1985), uma transação ocorre quando uma 
mercadoria ou serviço transita por uma interface tecnologicamente separada, encerrando um estágio da atividade e começando outro. Estas interfaces estão ligadas por relações de contrato e carregam em si um custo para serem efetivadas. Ou seja, esta abordagem conceitual de transação está voltada à identificação dos elementos promotores da redução de custos na consecução das atividades econômicas.

Neste sentido, a economia dos custos de transação se alinha com a tradição ortodoxa da microeconomia (otimização) ou com a Organização Industrial (OI), uma vez que também tem como preocupação central o exame de formas eficientes na organização da produção. Assim, as duas correntes teóricas - ECT e OI - são complementares, e principalmente o são na medida em que as estratégias competitivas das empresas podem influenciar a especificidade dos ativos e, por conseguinte, os custos da transação (Siffert Filho, 1995).

A diversidade contratual, por sua vez, origina numerosas questões, de cuja solução se ocupa o estudo das instituições econômicas do capitalismo. A Economia dos Custos de Transação sustenta que tal diversidade se explica principalmente pelas diferenças subjacentes nos atributos das transações, mormente quanto à especificidade dos ativos envolvidos. Assim, os propósitos de eficiência são satisfeitos adaptando-se as estruturas de governança aos atributos das transações, e, relacionando-se os tipos contratuais à eficiência destas transações sob uma forma analitica (Zylbersztajn, 1995).

O tipo de análise utilizado é a estrutural discreta comparada, que significa um enfoque comparativo entre formas de governança alternativas e os seus respectivos atributos, cujos fatores determinantes destas formas são ditados segundo um critério minimizador dos custos de transação, ou seja, com base em critérios de eficiência (Williamson 1985).

Segundo Williamson (1985), o alinhamento das estruturas de governança é condicionado por três grupos de fatores: 
- Características das transações - especificidades dos ativos, freqüência e grau de incerteza, consideradas a unidade básica de análise.

- Ambiente institucional, considerado o vetor de fatores de deslocamento do modelo, tais como tradição legal, existência de leis de proteção intelectual, mudança nos padrões de competitividade, aspectos culturais e outros.

- Pressupostos comportamentais, racionalidade limitada e oportunismo, ambos relacionados à incompletude dos contratos.

A forma de governança emergente a partir destes grupos de fatores condicionantes deverá compatibilizar os custos associados à estruturação dos contratos aos incentivos próprios de cada arranjo contratual e aos custos burocráticos respectivos.

Macneil (1978) foi o principal autor a elaborar uma resenha sobre a diversidade contratual. Este autor apresenta uma classificação triplice dos contratos, observando que todo o sistema de direito contratual tem o propósito de facilitar as transações. Sinteticamente, o autor define três classificações de contratos:

1) Clássicos, cujas transações são isoladas, descontínuas, discretas, não há identidade das partes contratantes, presença de regras claras e ajustes via mercado. A natureza do acordo é cuidadosamente delimitada e $\circ$ mais formal possivel, e as conseqüências são relativamente previsiveis no início. A ênfase, então, é dada aos regulamentos legais, documentos formais e transações autoliquidáveis. Um exemplo deste tipo contratual são os contratos em bolsas de mercadorias.

2) Neoclássicos, com transações contínuas e adaptáveis, que consideram a existência de racionalidade limitada e de incerteza dos 
agentes, a necessidade de mecanismo de controle ( uma terceira parte, o árbitro) e a manutenção do contrato original como referência para a negociação. Um exemplo são as vendas futuras.

3) Relacionais, com transações mais flexíveis, que prevêem a possibilidade de renegociação contínua, e, em contraposição ao contrato neoclássico, o contrato original deixa de servir como base de negociação e os ajustes são permanentes, a relação se sustenta com o relacionamento corrente. Este é o principal tipo contratual utilizado entre produtor e indústria em sistemas agro-industriais.

Segundo Williamson (1985), os agentes ao realizarem investimentos irreversiveis e especializados fazem comprometimentos e ameaças acreditáveis. Os comprometimentos são requisitos para a realização dos contratos que buscam garantir alianças e trocas. As ameaças, por sua vez, visam diminuir os conflitos e as rivalidades. Desta forma, os comprometimentos compõem-se de atos reciprocos designados com o objetivo de proteger $\circ$ relacionamento entre os agentes. As ameaças são esforços unilaterais para coibir uma situação de vantagem. Estas vantagens dizem respeito ao poder de barganha das partes e para tanto há um sistema de incentivos, cujo objetivo é a divisão de ganhos.

Para fins de eficiência econômica, a relação contratual deve estar definida e ajustada segundo a estrutura de governança compativel. Ou seja, a forma como a transação transcorre está diretamente relacionada ao comportamento esperado dos agentes e como eles reagem às informações disponiveis no mercado e sobre seu investimento em questão. O quadro 1 ilustra as possiveis formas contratuais adotadas segundo a caracteristica do investimento exigido e a freqüência das transações.

Nesse sentido, a governança de mercado é a principal estrutura para as transações não especificas da contratação ocasional e recorrente (contratação clássica). A identidade das partes tem importância insignificante, o conteúdo 
substantivo se determina por referência aos termos formais do contrato e se aplicam as regras legais (litígio) em caso de conflitos. As alternativas de mercado são nada mais que aquelas que protegem a cada parte contra o oportunismo de seu oponente. O litígio, ou justiça, reserva-se, estritamente, para a coordenação das reclamações.

QUADRO 1: Governança Eficiente

\begin{tabular}{|c|c|c|c|c|}
\hline \multicolumn{2}{|c|}{} & \multicolumn{3}{|c|}{ Característica do investimento } \\
\cline { 3 - 5 } & não especifico & misto & Idiossincrático \\
\hline $\begin{array}{c}\text { Freqüência } \\
\text { da } \\
\text { transação }\end{array}$ & ocasional & $\begin{array}{c}\text { Mercado } \\
\text { (contrato clássico) }\end{array}$ & $\begin{array}{c}\text { Trilateral } \\
\text { (neoclássico) }\end{array}$ & $\begin{array}{c}\text { Trilateral } \\
\text { (neoclássico ou } \\
\text { governança unificada) }\end{array}$ \\
\hline & recorrente & $\begin{array}{c}\text { Mercado } \\
\text { (contrato clássico) }\end{array}$ & $\begin{array}{c}\text { Bilateral } \\
\text { (contrato relacional) }\end{array}$ & $\begin{array}{c}\text { Governança Unificada } \\
\text { (contrato relacional) }\end{array}$ \\
\hline
\end{tabular}

Fonte: Adaptado de Williamson (1985)

Considerando o pressuposto de racionalidade limitada dos agentes, observa-se que os contratos são complexos e incompletos, e como estão sujeitos a ações oportunísticas, eles são vulneráveis à quebra, geralmente motivados pela existência de quase-rendas. Nestes casos, em geral, o mercado é visto como uma forma menos eficiente para lidar com a governança das transações por decorrência da inexistência de proteção para nenhuma das partes. Em casos de dependência bilateral e transações recorrentes que não exijam inversões idiossincráticas, a governança bilateral por meio de contratos relacionais passa a ser a mais eficiente.

A governança trilateral é a apropriada para as transações ocasionais de tipo mista e de tipo idiossincráticas (que envolvem alta especificidade de ativos). Nestes casos, necessita-se de uma forma intermediária ao mercado e à forma bilateral, pois há fortes incentivos para vigiar o cumprimento do contrato até o seu término. Não somente se têm inversões especializadas, cujo custo de oportunidade é alto, como também a transferência de tais ativos a 
outro fornecedor acarretaria enormes dificuldades de revalorização. Assim, a contratação neoclássica é a governança que atende aos propósitos desta relação: em vez de se recorrer de imediato ao litígio judicial, recorre-se à assistência de um terceiro membro para a resolução dos possiveis conflitos.

A governança bilateral é aquela utilizada em formas mistas de contratação, onde os ativos envolvidos são específicos mas as partes contratantes são independentes. Entretanto, a dependência bilateral é forte para ambas as partes. $O$ interesse é mútuo para que tudo funcione bem. Difere da governança unificada, onde os ativos são altamente especificos (relações idiossincráticas) e a transação se organiza internamente à firma (integração vertical ou hierarquia). Ambas, entretanto, caracterizam uma contratação relacional. 


\section{Metodologia}

\subsection{Caracterização da pesquisa e coleta de dados}

Trata-se de uma pesquisa econômica aplicada ${ }^{10}$, de caráter exploratório e descritivo, que buscou analisar através de um estudo de caso a estrutura de funcionamento das relações contratuais $e$ as formas de governança estabelecidas entre o segmento produtor e processador de leite no País. O objetivo desta pesquisa foi proporcionar uma visão geral, de tipo aproximativo, acerca do fenômeno em estudo dentro do contexto nacional.

A amostra selecionou produtores da bacia leiteira de uma única empresa ${ }^{11}$ laticinista na região Sudoeste de Minas Gerais. O escopo de captação de leite da empresa selecionada é nacional, sendo padrão o tipo de relação adotada entre a mesma e seus fornecedores de leite. Assim, escolheu-se a referida região em virtude das maiores facilidades de acesso, apoio dos técnicos e menores custos.

10 A pesquisa econômica aplicada tem como característica fundamental o interesse na aplicação, utilização e conseqüencias práticas dos conhecimentos científicos. Ao contrário da pesquisa econômica pura, sua preocupação está menos voltada para o desenvolvimento de teorias de valor universal que para a aplicação imediata numa realidade circunstancial (Mattar, 1993)

11 Não foi permitida a declaração do nome da empresa que forneceu os dados para esta pesquisa. A empresa foi escolhida para o estudo devido à sua importância no agribusiness mundial e, especificamente, em lácteos. Além disso, ela é uma das pioneiras na implantação do processo de coleta a granel de leite refrigerado no Estado de Minas Gerais e, sobretudo, tem incentivado progressivamente os seus fornecedores de matéria-prima (leite) a se especializarem e modernizarem sua produção, tanto quantitativa como qualitativamente. 
Como se trata de uma pesquisa de campo, a coleta de dados primários procedeu-se, basicamente, por meio de questionário ${ }^{12}$ e via entrevistas individuais, realizadas pessoalmente pela própria autora. Esta forma de investigação possibilitou, de certa maneira, que o entrevistado expressasse livremente suas percepções, crenças, valores, opiniões, atitudes a respeito do processo de granelização da coleta de leite na região.

Há que se relatar, contudo, que houve falhas na estruturação do questionário e, consequentemente, nas entrevistas. Isto gerou dificuldades seguintes na tabulação dos dados. Como não houve tempo nem disponibilidade de recursos financeiros para um pré-teste do questionário, as respostas, de caráter subjetivo, não puderam ser quantificadas ou analisadas estatisticamente. Procedeu-se a uma descrição analítica e qualitativa das entrevistas como forma de apresentação dos resultados.

Além da caracterização comportamental dos agentes na relação contratual, buscou-se coletar junto à empresa em estudo informações sobre o volume de leite transportado por quilômetro percorrido, custos de frete por quilômetro percorrido, freqüência da coleta, gastos com pagamento aos carreteiros, despesas com manutenção da frota e outras despesas com frete, compromissos sinalizados pelas partes, e outras variáveis relevantes para a análise da economia de custos comparadas antes e após a granelização da coleta.

Os dados foram coletados no mês de abril de 1998 e se referem ao ano agrícola de 1997/98, o primeiro configurado após a implantação do processo em agosto de 1996. A amostra compôs-se de 45 produtores distribuídos na bacia leiteira desta região e que pertencem ao distrito leiteiro de Ibiá. Este número corresponde a $10 \%$ do total de produtores, na região, que na época da pesquisa de campo já tinham sua coleta de leite granelizada. Hoje, este percentual chega a $60 \%$ sendo a expectativa de que em 2001 100\% dos

\footnotetext{
${ }^{12}$ Questionário utilizado em anexo C.
} 
produtores estejam integrados no processo de resfriamento do leite $e$ granelização da sua coleta.

O critério adotado para a distribuição nos três estratos de produção foi o volume de leite entregue por dia por cada produtor. $O$ objetivo de dividir a amostra em três estratos foi permitir que diferenças entre pequenos, médios e grandes produtores pudessem ser melhor caracterizadas na análise dos resultados.

Como representantes da empresa (aqui denominada "indústria"), foram entrevistadas três pessoas: o idealizador do processo de coleta a granel da empresa, o gerente da unidade laticinista numa das unidades da empresa em Minas Gerais, e o técnico responsável pela assistência aos produtores e pelo suporte do projeto.

De acordo com o técnico responsável pela granelização do leite na fábrica de Ibiá, classificou-se como pequenos aqueles produtores cuja produção diária em litros de leite situa-se entre 50 e 170 litros, os médios, entre 170 e 450 litros e os grandes produtores, acima de $450 \mathrm{l} / \mathrm{d}$. Há que se deixar claro, entretanto, que a média geral de produção de leite por produtor, na região estudada, é de $150 \mathrm{l} / \mathrm{d}$, ou seja, há uma predominância de pequenos produtores.

O tamanho da propriedade em hectares pouco afetou a presente classificação, uma vez que a maioria delas têm menos de 100 ha. Como o leite coletado na região tem destino industrial (processamento de leite em pó), também não se diferenciou os produtores amostrados segundo o tratamento dado às pastagens, o manejo do gado, a capacitação tecnológica do produtor e da fazenda (instalações e equipamentos), pois os meios de produção adotados são indiferentes para a indústria. Por isso o volume de leite produzido ao dia foi o principal critério definidor dos estratos amostrais. 


\subsection{Procedimentos Metodológicos}

Com o fim de avaliar as transações ocorridas no segmento produçãoprocessamento do sistema leite, utilizou-se uma metodologia de análise comparada de formas de governança presentes entre estes agentes, vistas bilateralmente segundo a importância do negócio em questão para cada uma das partes.

Esta análise baseou-se no estudo de Loader (1992), onde este autor, considerando as assertivas de Williamson (1985), ilustra as relações de compra e venda de batatas na Inglaterra, na cadeia de produção e na exportação. Naquele estudo, o autor analisou as ditas relaçöes segundo os pressupostos comportamentais dos agentes envolvidos e a estes relacionou a estrutura de governança presente e a forma esperada, mais eficiente.

Como se tratava de questionamentos subjetivos, o autor inovou na forma de codificação das respostas, atribuindo-Ihes notas segundo a importância revelada pelo agente na respectiva transação. Desta forma, ele conseguiu montar quadros onde se pudesse comparar as transações entre os agentes, e a forma de governança esperada para cada uma das trocas da maneira mais eficiente possível. O anexo $E$ representa o modelo utilizado.

A hipótese deste método é avaliar se as relações organizacionais no sistema agro-alimentar se alinham ou não com os atributos estimados das transações pela razão de minimização de custo de transação e de coordenação da cadeia, trazendo com isso eficiência de governança. Foi por esse motivo que a referida metodologia de análise de relações contratuais foi escolhida para ser utilizada no presente trabalho. Dadas as dificuldades descritas para a quantificação das respostas dos questionários, a apresentação dos resultados deste estudo foi disposta textualmente e não por meio de quadros como o modelo que se descreve a seguir, muito embora o padrão de análise tenha sido o mesmo da descrição dos quadros. 
O quadro modelo apresenta três partes, possibilitando que a análise da transação e, por conseguinte, da categoria contratual seja desagregada numa série de partes componentes. A primeira parte desta tabela permite a descrição das relações: a descrição do contrato, e os objetivos da transação. A segunda parte sumariza os elementos da transação concernente, e na parte final, ou terceira, a estrutura de governança esperada, dados os níveis das variáveis tomadas, é especificada e comparada com o que atualmente ocorre na situação particular.

Entretanto, na condução da pesquisa, verificou-se que o método foi falho em termos da atribuição subjetiva de notas para os atributos dos agentes. Este fato justificou a decisão de ter-se procedido no presente estudo somente em análises descritivas e qualitativas, sem julgamento de valor.

As perguntas foram elaboradas de forma indireta a fim de que pudessem ser interpretadas segundo os atributos da transação. Por exemplo, para verificar o grau de incerteza na relação foi perguntado a ambas as partes, produtor e indústria, "em que aspectos eles se sentem dependentes ou vulneráveis em relação ao outro. Se o produtor especializado quiser sair do negócio ele tem como vender o resfriador e outros ativos e recuperar seu investimento? $E$ a indústria, que fez o financiamento dos tanques, como the será garantido o recebimento do leite do produtor? (para verificar sunk costs e especificidade de investimento dedicada ao negócio). Se, por algum motivo, a relação for desfeita, o produtor tem para quem entregar seu produto? E a indústria, teria de quem continuar recebendo sua matéria prima na região?(especificidade locacional/perecibilidade do leite). Em condições vantajosas, alguma das partes mudaria de parceiro? (oportunismo)". As demais perguntas constam no anexo $B$.

Embora não se tenha utilizado o mesmo quadro para apresentar os resultados, a análise compreendeu todos os atributos em questão. A transação 
foi caracterizada nas duas direções, do produtor para a indústria, como vendedor de leite, e da indústria para o produtor, como compradora. Esta caracterização bilateral permitiu a visualização da relação de poder no elo concernente, sob o ponto de vista das duas_partes isoladas, o que enriquece a análise. Além disso, as transações foram analisadas segundo o ambiente institucional corrente. Isto permitiu inferir prováveis mudanças nas relações entre os agentes caso alguma mudança fundamental no padrão competitivo do sistema leite seja verificada. 


\section{A Coleta a Granel no Brasil e no Mundo}

Atendendo ao objetivo secundário proposto no estudo, este capitulo aborda o processo de intensificação da coleta a granel e o desenvolvimento da economia leiteira de alguns Países no mundo e no Brasil.

\subsection{Estados Unidos}

Nos Estados Unidos, a formalização do processo de coleta a granel de leite, resfriado nas próprias fazendas produtoras, deu-se em 1957, na Conferência de Michigan, onde se reuniram economistas, membros do governo e representantes de segmentos produtivos do sistema agro-industrial do leite daquele País.

Naquela época, a economia leiteira nos Estados Unidos estava entrando num novo ciclo dos três "big shifts" ocorridos neste século. Segundo Hamm (1997), os "big shifts" foram responsáveis por mudanças traumáticas às gerações de produtores de leite em épocas diferentes, épocas estas que formam um ciclo a cada 30 anos.

As grandes viradas na economia leiteira deste País ocorreram quando houve, simultaneamente, uma mudança fundamental em dois ou três dos seguintes fatores:

- mudança na tecnologia de oferta de leite, tanto nas fazendas quanto na distribuição de leite aos consumidores;

- mudança no mercado dominante de leite e derivados; 
- mudança na estrutura de mercado e nas relações econômicas de poder.

Os ciclos, por assim dizer, poderiam ser apresentados em três períodos marcantes para este País no presente século. O primeiro foi configurado nos anos 30. Naquela década, os Estados Unidos tinham milhões de propriedades rurais com atividades diversificadas, muitas delas tendo apenas umas poucas vacas e uma variedade de outros animais criados conjuntamente.

Com a eletrificação rural e a homogeneização/pasteurização do leite houve uma especialização forçada dos produtores de leite. O produto de mercado exigido passou a ser o leite fluido, que, desde então, começou a ser entregue em garrafas de vidro na porta das casas dos consumidores.

A massiva urbanização e $\circ$ aumento da renda disponivel dos consumidores tornou-os desejosos e aptos a pagar por leite fresco. A comercialização do leite fresco, por sua vez, exigiu que fossem criados órgãos regulamentadores do produto e de sua composiçāo química. Com isso, a precificação do produto passou a valorizar os componentes de gordura contidos no leite. Diante de contínuas mudanças e exigências crescentes, o resultado foi um processo gradativo de exclusões de produtores que não conseguiram se adaptar rapidamente às mudanças e, por isso, escolheram ou foram forçados à deixar a atividade.

Nos anos 60, o ciclo foi marcado por uma redução drástica no número de produtores atuantes na atividade leiteira. Os fatores que determinaram estas mudanças foram:

- a refrigeração do leite a granel em tanques instalados nas propriedades rurais, sob determinação do Estado, resultando num gigantesco reinvestimento feito pelos produtores que desejavam se readaptar ao novo sistema;

- o produto de mercado - leite fluido ainda dominante - passou a ser distribuido aos consumidores por supermercados e não mais por entregadores locais nas portas das casas;

- o poder nas relações de mercado passou a ser ditado pelas 
organizaçōes regionais tanto de processadores como de produtores.

Neste período, cerca de $50 \%$ dos produtores abandonaram a atividade em apenas 3 anos. A exclusão só não foi maior devido ao ganho de poder político que as cooperativas obtiveram ao longo dos anos 60 e 70 junto ao governo.

Os anos 90 , por sua vez, foram marcados por uma forte especialização da pecuária, não só dos produtores mas também das regiões produtoras nordeste e meio-oeste - regiōes estas que são as mais favoráveis também à produção alimentar para o gado, mão-de-obra suficiente ao trabalho e gerenciamento das propriedades, bem como facilidade de acesso aos bancos para provisão de capital aos contínuos investimentos.

A separação do trabalho e do capital no gerenciamento nas fazendas não somente propiciou uma vantagem de eficiência em tamanho e em escala, como também permitiu que as mesmas se tornassem altamente especializadas em produtividade e igualmente eficientes em racionalização de custos.

O preço do leite passou a ser, então, ditado pelo mercado de queijo e não mais pelo de leite fluido, com antes o era. Com a melhoria da qualidade da matéria-prima, o alvo de atenção aos lucros passou a provir do rendimento industrial que aquela permitia, e consequentemente, dos seus derivados diretos.

$\mathrm{Na}$ estrutura de mercado a mudança ficou por conta da inovação no sistema de distribuição e de aquisição de leite: foi a chamada "Síndrome Wall Mart" (Hamm. 1997). Preferivelmente a ter muitos ofertantes vendedores de leite para os distribuidores nacionais do produto, alianças estratégicas foram sendo formadas entre um grande comprador e uns poucos, e selecionados, vendedores. Isto significava vender o produto leite dentro das especificações de qualidade propostas pelo varejista, ao menor preço possivel.

Com estas medidas, o centro de produção de leite voltou-se para a costa oeste, onde seria mais facilmente adaptado ao novo modelo industrializado de produção especializada de leite para a indústria. Os antigos centros produtores 
do nordeste e meio-oeste permaneceram apenas como mantenedores de market share e de abastecimento regional.

Recentemente, estas mudanças trouxeram outras conseqüências e alertaram o agribusiness do leite no País para novas tendências:

- Os preços mais baixos na Califórnia sinalizam uma contínua dominância dos preços dos produtos da costa oeste a nivel nacional;

-Adequação das capacidades das plantas produtoras para evitar inflações nos preços;

- Competição intensa entre grandes produtores. À medida que as fazendas buscam sua plena capacidade, a tendência é de que se ofereçam prêmios aos grandes produtores que entreguem tanques carregados de leite diariamente.

- Crescente número de fusões entre cooperativas. Para o remanejamento eficiente de suprir grandes demandas dos grandes compradores tipo o Wall Mart, as cooperativas foram forçadas a olhar para as fusões como forma de crescer e ganhar mercado.

- Contínua volatilidade dos preços, causadas principalmente por freqüentes mudanças na oferta e na demanda de leite (desequilibrio na oferta, muitas vezes influenciado por variações na importação e na segmentação do mercado consumidor), perda de suporte de preços pelo governo e natureza dinâmica dos mercados.

- Movimento em direção aos contratos de preço/produção. Com o fim de manter os fornecedores e reduzir a volatilidade dos preços, os compradores vão direto aos grandes produtores, direcionando-se assim aos contratos por preço, mas premiando volume.

- Globalização de mercados: apesar das exportações não terem crescido muito acima daquelas nos anos 80 , há um ingresso crescente de firmas estrangeiras nos Estados Unidos, que compram leite dos produtores americanos e vendem interna e externamente ao País. 
Pelos cenários descritos percebe-se que a retomada do agribusiness do leite nos Estados Unidos voltou-se claramente a uma estrutura mais coordenada do sistema produtivo, sendo os padrōes de consumo e de distribuição os ditantes desta nova fase.

Estes ciclos descritos também foram observados em outros países desenvolvidos em pecuária leiteira, como Inglaterra e Nova Zelândia, muito embora não tão definidos.

\subsection{Reino Unido e Nova Zelândia}

No Reino Unido, a formalização da coleta a granel de leite refrigerado deu-se em 1970 (Soares, 1996). A partir daí, as normas de produção, de padronização de higiene e de qualidade do produto foram sendo adotadas paulatinamente. Hoje, a modernização do setor leiteiro neste país está totalmente integrada, desde as unidades de pesquisa, melhoramento genético de animais e de alimentação para o gado, cuidados no manejo, instalação dos animais, ordenha, testes físico-quimicos, transporte, armazenamento e distribuição ao consumidor ${ }^{13}$.

Nos últimos 60 anos a indústria laticinista do Reino Unido também passou por grandes mudanças. Uma delas se deveu à desregulamentação do estatuto que exigia que todo o leite produzido deveria ser entregue a uma junta mercantil, que foi extinta em novembro de 1994. A dúvida que pairou no ambiente para produtores e indústria foi sobre o preço futuro do leite após a desregulamentação, visto que a antiga junta mercantil era formada por cooperativas que, a partir de então, encontravam-se em grande concorrência com as indústrias laticinistas.

Esta guerra de preços, por sua vez, incentivou os constantes aprimoramentos técnicos que a atividade leiteira passou a exigir em todo o 
mundo. A título de ilustração pode-se citar que, em 1975, existiam no Reino Unido aproximadamente 75 mil produtores de leite e, em 1993 eles eram apenas 39 mil. Um grande número de produtores tem deixado a atividade, mas em contrapartida a produção por fazendeiro tem aumentado (Anais do Seminário de Leite - OCEMG, 1994).

Esse aumento de produtividade só não foi maior em virtude do controle exercido pelas cotas de produção de leite. Estas cotas têm a função de controlar a quantidade produzida de leite nos Paises da região a fim de evitar excedentes na Comunidade Européia e, consequentemente, queda do preço do produto. Assim, a lucratividade da atividade passou a ser respondida diretamente pelo aumento do preço do leite, devido a problemas de abastecimento na Europa. Os principais beneficiários foram as grandes fazendas, que são maioria no Reino Unido ${ }^{14}$.

O impacto das cotas de produção para as indústrias foi a insuficiência de leite para o processamento de seus produtos $e$, consequentemente, a ociosidade da fábrica resulta em custos muito altos de operacionalização. Nesse sentido, a guerra pelo mercado se tornou intensa no Reino Unido. Algumas empresas começaram a usar a estratégia de atrair para si apenas os pequenos produtores, que estão mais afastados do mercado, tentando convencê-los a entregar o seu leite dia sim dia não. As próprias empresas encorajam estes pequenos produtores a entregarem seu leite em dias alternados - o que antes era normalmente feito todos os dias -, montando uma estrutura de preços que está relacionada ao volume fornecido.

Alguns produtores organizados, no entanto, fazem contratos diferenciados

\footnotetext{
${ }^{13}$ Ver mais sobre 0 assunto em Soares (1996).

${ }^{14}$ A estrutura das fazendas do Reino Unido também é diferente que a dos outros paises da Comunidade Européia. No Reino Unido elas são muito maiores devido às diferentes leis de herança que ocorrem na Europa. No geral, estas leis determinam que os proprietários devem deixar as suas fazendas para todos os seus filhos, enquanto que no Reino Unido elas são deixadas apenas para o filho mais velho. Como resultado têm-se fazendas muito grandes, com grandes rebanhos e grande produçăo (Sandrey and Reynolds, 1990).
} 
com as indústrias, podendo oferecer exatamente a matéria-prima que elas desejam. Esses contratos são direcionados pela demanda e podem exigir qualidade, volume e composição. Existem contratos que garantem o fornecimento de leite de acordo com a produção e, também, o chamado "contrato residual", para o fornecimento de leite de baixo preço, em determinados momentos do ano (Soares, 1996).

Sob o ponto de vista do consumidor, as principais mudanças dizem respeito à forma como o leite é distribuído. O consumo é feito principalmente na forma fluida (cerca de $50 \%$ do leite produzido). Em 1982, $90 \%$ do leite era comercializado em garrafas de vidro e, praticamente dez anos depois, apenas $10 \%$ era vendido nesta forma. A predominância atual é das garrafas de plástico e embalagens de papelão, que podem ser abertas e fechadas, sendo muito práticas para o consumidor. Os produtos dietéticos e com baixo teor de gordura também estão ganhando a preferência dos consumidores no País (Anais do Seminário Leite - OCEMG, 1994).

A Nova Zelândia passou pelo mesmo processo de modernização da pecuária leiteira. Em março de 1943 o governo reuniu uma Comissão do Leite para discutir a respeito de métodos de fornecimento, coleta, tratamento e distribuição com o intuito de adequar a oferta de leite de qualidade a um preço razoável. O resultado do proposto acima foi a implementação de padrões de qualidade para o leite.

Neste periodo ficou definido pela Comissão que o controle do tratamento e da distribuição do leite seriam de responsabilidade pública, e a organização da produção e das vendas ficariam a cargo de considerações comerciais dos vendedores. Além disso, o relatório recomendava o controle de preços e a reorganização da indústria a fim de assegurar a adequação dos objetivos propostos inicialmente (Sandrey and Reynolds, 1990).

Como no Brasil, a indústria leiteira da Nova Zelândia começou com um grande número de pequenos produtores que possuiam pequenas áreas. A 
indústria produzia muito queijo e toda a produção era exportada para o Reino Unido. Na década de 20 , houve o desenvolvimento das cooperativas e foi formado o "Grupo de Laticínios da Nova Zelândia", que tinha toda a responsabilidade pelo marketing e venda dos produtos de laticínios. A relação entre o grupo leiteiro e as cooperativas indicava o tipo de produto que elas iriam produzir, caso houvesse incentivos para essa produção.

No final da década de 30 houve a formação de uma nova cooperativa, que foi na verdade uma união daquelas já existentes, e esta é uma característica dos últimos 50-60 anos. De 180 cooperativas que existiam em 1960, em 1975 restavam apenas 75, e hoje não passam de 10. Esta redução no número de cooperativas foi provocada pelas fusões constantes que cercaram o cooperativismo leiteiro na Nova Zelândia, ao passo que também foram resultado de exigências constantes de qualidade nos lácteos, que eram praticamente voltados ao mercado externo. Os produtos eram pouco elaborados, muito vulneráveis e com pouca importância na economia mundial. Com a união, as cooperativas se tornaram maiores e seus produtos mais diversificados (Rentero, 1998).

A entrada do Reino Unido na Comunidade Econômica Européia e a conseqüente redução do mercado de leite naquele País, antes abastecido pela Nova Zelândia, também fez com que se investisse na busca por novos mercados e na diversificação dos produtos, o que a longo prazo, beneficiou muito a indústria nacional de laticinios.

A partir dos anos 90 , as pequenas cooperativas foram retiradas do mercado pelas grandes cooperativas e o mercado de leite fluido caiu muito $85 \%$ do leite produzido passou a ser manufaturado e destinado à exportação. Atualmente há uma grande amplitude de produtos se expandindo rapidamente e uma competição agressiva no mercado global. Além disso, desapareceu a entrega em garrafas de vidro de $600 \mathrm{ml}$ no mercado interno (situação que existia até 1970), e os produtos de laticinios passaram a ser vendidos em 
supermercados com uma maior variedade.

Entre os fatos relevantes nesta última década está a integração horizontal de cooperativas, a incorporação de companhias privadas a cooperativas e a produção de leite em sua maioria sendo feita em pequenas fazendas próximas das cidades, sem contudo deixar de existir a participação de fazendas um pouco maiores e mais especializadas.

O fato mais marcante foi a redução do apoio governamental para a agricultura. O governo privatizou quase tudo que tinha, retirou subsídios e os empréstimos, e a indústria passou a se auto-administrar. Houve também uma redução de tarifas e impostos em geral e uma grande concorrência com produtos importados. O beneficio destas medidas foi o estímulo natural que o livre mercado gerou, obrigando a indústria - antes ineficiente - a se modernizar, crescer e melhorar.

Estes foram o resultado da política de integração do setor adotada no Pais, que permitiu que os agentes produtivos ficassem muito mais competitivos, além de cooperativos, e orientados para o mercado.

\subsection{Brasil}

No Brasil, não se pode definir fases na evolução da pecuária leiteira nacional. Como o setor esteve sob regulamentação de preços de 1945 a 1991, as práticas de mercado - comumente incentivadoras da modernização produtiva nos paises citados anteriormente - estiveram emperradas neste período.

"A história econômica do setor leiteiro esteve marcada por uma história do contra: contra a fraude (adição de água ao leite), contra a transmissão de doenças como a brucelose ou a tuberculose (o leite é um excelente meio de cultura de bactérias patogênicas), e contra a deterioração do leite, que após a ordenha se perde facilmente quando mantido à temperatura 
ambiente" (Meireles, 1996, p.12).

Nessa história, não se faz necessário classificar períodos definidos, pois ao longo deste século pouco se evoluiu em termos de padrões de qualidade e de distribuição do leite. Essa inércia se deveu principalmente ao longo periodo em que o controle dos preços esteve nas mãos do governo federal.

Até 1939 , os avanços no tratamento do leite diziam respeito somente ao processo de pasteurização do mesmo, que consistia em aquecer o leite durante 30 minutos a uma temperatura pouco superior a $61^{\circ} \mathrm{C}$. Isto o que representou a primeira vitória contra as bactérias patogênicas eventualmente presentes no leite cru, exceto as formas esporuladas e as toxinas, que não eram eliminadas (Meireles, 1996).

$\mathrm{Na}$ década de 40, através de um regulamento, o governo passou a exigir a pasteurização de todo o leite distribuido à população. Foi por meio deste regulamento que se definiu pela primeira vez três tipos de leite admitidos pela fiscalização: o leite tipo "A", tipo "B" e o tipo "C", com a exigência de que todos deveriam estar na forma "integral", com um mínimo de $3 \%$ de gordura. O local de beneficiamento, a redutase e a contagem de germes eram as principais caracteristicas diferenciadoras dos três produtos. A distribuição desses produtos ficaria a cargo das cooperativas, que começaram a se constituir a partir dos anos 30 .

Até a década de sessenta o processo de pasteurização foi sendo aperfeiçoado, primando não somente pela melhoria da eficiência dos equipamentos utilizados, mas também pela qualidade do leite. A distribuição, que era feita em embalagens de vidro, passou a ser gravada, nos anos 50 , com a marca da empresa que distribuía o leite. Com esta medida as empresas conseguiram superar dois dos principais problemas do leite: a fraude e a preservação do produto livre de germes patogênicos. Mas a falta de frio nos caminhões, principalmente no período de verão, continuava a ser problemática, 
tanto quanto a falta de cuidados de conservação no varejo.

Nos anos 60 , o processo de tratamento térmico utilizado passou a ser a esterilização, ao mesmo tempo em que surgia uma embalagem asséptica capaz de conservar melhor o produto. Este fato marcou o surgimento do leite longa vida, um leite fluido que dispensava a cadeia de frio, ao mesmo tempo em que, ao usar uma embalagem descartável, tornava desnecessária a operação de recolhimento e a higienização do vasilhame.

Devido a uma crise de abastecimento em meados dos anos 70 e início dos 80 , o leite B passou a ter um volume expressivo de venda nos grandes mercados. Entretanto, nesse mesmo período, devido a uma política do governo redutora de preços ao consumo, houve um crescimento significativo das importações de leite em pó, que serviria às exigências do leite reconstituído para o mercado interno.

Ao final da década de 80 , pouco se modificou na cadeia agro-industrial do leite em termos de avanços em qualidade do produto comercializado. Os sistemas de transporte e de distribuição de leite pasteurizado permaneciam os mesmos de décadas anteriores. Tentativas de colocar aparelhos de refrigeração nos caminhões não prosperaram, seja pelos altos investimentos que requeriam um produto tabelado e pouco lucrativo, seja pela eficácia duvidosa dos aparelhos.

Estas características do mercado de leite fluido só começaram a se mostrar significativas a partir da década de 90. Nos últimos sete anos o segmento agro-industrial do leite passou a vivenciar mais mudanças do que aquelas que experimentou nos 45 anos que antecederam a presente década. Essas mudanças ocorreram em razão das transformações institucionais pelas quais o País vem passando.

A desregulamentação do mercado de leite, a abertura comercial, a consolidação do Mercosul, e a estabilização da economia com o Plano Real também representaram mudanças significativas no ambiente geral de normas e 
práticas sociais correntes, no qual as empresas atuam e, hoje em dia, têm papel decisivo. Nesse sentido, o processo de modernização da pecuária leiteira ganhou um caráter de revolução e não de evolução, onde, mesmo sem querer, salta algumas etapas e concretiza outras, simultaneamente.

Com o fim do controle estatal sobre os preços acirrou-se a concorrência entre as empresas em todos os elos do sistema leite. Se por um lado as empresas voltaram suas preocupações à aquisição de matéria-prima selecionada, por outro, a venda de produtos finais engajou-se num novo processo de segmentação do mercado consumidor, que se mostrava cada vez mais exigente por qualidade, conveniência e praticidade dos produtos lácteos. Nesse sentido, o leite longa vida ganhou espaço na comercialização feita através de supermercados, devido ao seu maior shelf life (Jank e Galan, 1997).

Ao aproximar produtores distantes de grandes varejistas, o leite esterilizado provocou o equilibrio das bacias leiteiras que, tradicionalmente, abasteciam mercados locais pulverizados em milhares de pontos de vendas. $O$ resultado foi semelhante àquele ocorrido nos anos 30 nos Estados Unidos: o grande varejo promoveu forte competição entre indústrias e o leite longa vida se transformou no produto regulador do mercado de leite, substituindo o papel que era antes desempenhado pelo leite em pó reidratado na entressafra.

A tendência geral a partir da liberação de preços e do fim da intervenção do governo no setor apontou para o fim de produtores e indústrias ineficientes que antes operavam neste mercado.

A concorrência desencadeada com a desregulamentação do setor foi intensificada com a abertura comercial e a consolidação do Mercosul. A antiga prática do governo de regulação do mercado interno com importações em épocas de entressafra modificou-se na década de 90, muito embora ainda continuem a existir agentes importadores, que não empresas do setor, que se aproveitam de vantagens nos diferenciais de juros e de câmbio permitidos pela política pública. Estas práticas provocaram distorção nos preços internos, 
principalmente em função do excedente de oferta de leite que foi gerado (Jank e Galan, 1997).

Por outro lado, as importações de produtos mais baratos da Argentina e do Uruguai pressionaram o sistema agro-industrial do leite brasileiro por um redirecionamento nos seus parâmetros de competitividade, notadamente redução de custos e aumento de qualidade, desde a produção até a comercialização.

A estabilização dos preços, propiciada com o Plano Real, também foi um fator de mudança no ambiente competitivo do Pais. Além de extinguir agentes ineficientes do mercado estimulou o desenvolvimento de novas bacias leiteiras e o deslocamento da região produtora para o Centro-oeste, em virtude dos custos baixos da terra e da proximidade com a área produtora de grãos e de alimentos para o gado. Paralelamente à busca por custos baixos, a necessidade de qualidade na produção e no transporte de leite tornou-se urgente.

Nesse sentido, o resfriamento do leite nas fazendas, imediatamente após a ordenha, e o transporte do leite frio e a granel passaram a representar o mais recente arranjo estratégico do setor, através da seleção de produtores, melhoria na tecnificação da produção e distribuição de produtos com maior qualidade. Além disso, a coleta a granel permite que os postos de processamento não estejam necessariamente situados nas respectivas bacias leiteiras de fornecimento. O leite resfriado resiste ao transporte por percursos mais longos sem comprometer sua qualidade.

Ainda se tratando da importância estratégica que o processo veio representar, não se pode deixar de mencionar que o mesmo também representa um estímulo à organização produtiva privada e à criação de sistemas de pagamento por qualidade regulamentada pelas autoridades competentes do governo, como aqueles que já vigoram em alguns Paises desenvolvidos em pecuária leiteira. 


\section{Qualidade do Leite no BRAsil e no Mundo}

Ainda cumprindo a proposta do objetivo secundário do estudo, este capítulo traz uma narrativa sobre um amplo estudo, realizado em 1995 pela Internatinal Dairy Federation Bulletin, a partir de informações sobre a pecuária leiteira de vinte e dois Países.

Naquele estudo, foram caracterizados os sistemas de avaliação e critérios de pagamento por qualidade, relações contratuais e formas de fiscalização e controle do leite comercializado naqueles Países.

Segundo o estudo, observa-se que os sistemas de pagamento por qualidade abrangem, atualmente, quesitos que vão desde a genética, alimentação e cuidados com o gado, tratamento do leite pós ordenha, até as formas relacionais utilizadas entre produtor e indústria, sem deixar de lado a importância também atribuida às normas para a coleta de leite e transporte.

Os quadros a seguir foram ordenados segundo o volume de produção de leite, em $1998^{15}$, nos principais Paises produtores no mundo. Nestes Paises, as diferenças nos sistemas de pagamento com respeito à determinação do preço, diferenciações, padrão de qualidade, prêmios e etc., são grandes. Não existe um sistema uniforme, pois as características produtivas são específicas a cada país. Apesar destas diferenças, são comuns a importância relegada ao nivel de proteina entregue, qualidade higiênica, leite resfriado e outros, conforme se vê no quadro 2 .

\footnotetext{
${ }^{15}$ Números fornecidos pelo Departamento Econômico da Confederação Nacional de Agricultura (CNA), Brasilia.
} 
Quadro 2: Expressão de preço e base de pagamento nos diferentes países

\begin{tabular}{|c|c|c|c|c|c|c|c|c|c|c|c|c|c|}
\hline \multirow[t]{3}{*}{ Pais } & \multirow{3}{*}{\begin{tabular}{|c|} 
Vol Produção \\
(1.000t) \\
"Fonte: CNA \\
1998
\end{tabular}} & \multicolumn{7}{|c|}{ Expressão de preço } & \multirow{2}{*}{\multicolumn{5}{|c|}{$\begin{array}{l}\text { Base de pagamento } \\
\text { Critério de componentes }\end{array}$}} \\
\hline & & \multicolumn{4}{|c|}{ Expressão de preço em termos de } & \multirow{2}{*}{$\begin{array}{c}\text { Sobre os } \\
\begin{array}{c}\text { componen- } \\
\text { tes }\end{array} \\
\end{array}$} & \multirow[t]{2}{*}{ Voluntário } & \multirow[t]{2}{*}{ Regulatório } & & & & & \\
\hline & & Volume & Peso & $\begin{array}{l}\text { Peso dos } \\
\text { sólidos }\end{array}$ & Outros & & & & Gordura & Proteina & Lactose & Sólidos & $\begin{array}{l}\text { Sólidos de- } \\
\text { sengordur. }\end{array}$ \\
\hline Estados Unidos & 71.375 & & Sim & & & Sim & $\mathrm{Sim}$ & & Sim & & & & $\operatorname{Sim}^{4}$ \\
\hline India & 35.600 & & & $\operatorname{Sim}$ & & Sim & & Sim & Sim & & & Sim & Sim \\
\hline Alemanha & 28.500 & & Sim & & & $\operatorname{sim}$ & & Sim & Sim & & & & \\
\hline França & 24.700 & $\mathrm{Sim}$ & & & & Sim & Sim & Sim & Sim & Sim & & & \\
\hline Brasil & 20.800 & $\operatorname{Sim}$ & & & & Sim & Sim & & Sim & & & & \\
\hline Reino Unido & 14.600 & Sim & & & & Sim & & $\operatorname{sim}$ & $\operatorname{sim}$ & & & & \\
\hline Polônia & 12.100 & & & & Sim & Sim & & Sim & Sim & & & & \\
\hline Nova Zelândia & 11.640 & & & Sim (prol+gord) & & Sim & Sim & & Sim & & & & \\
\hline Holanda & 11.200 & & Sim & Sim & & Sim & & Sim & Sim & & & & \\
\hline Austrália ${ }^{1}$ & 9.656 & Sim & & & & Sim & & Sim & Sim & Sim & & & \\
\hline Japão & 8.550 & & $\mathrm{Sim}$ & & & Sim & $\mathrm{Sim}^{2}$ & $\mathrm{Sim}^{3}$ & Sim & & & & Sim \\
\hline Canada & 8.200 & Sim & & Sim & & Sim & & Sim & Sim & & Sim & Sim & \\
\hline Irlanda & 5.681 & Sim & & Sim & & Sim & Sim & & Sim & & & & \\
\hline Dinamarca & 4,660 & & Sim & & & Sim & Sim & & $\operatorname{Sim}$ & & & & \\
\hline Bélgica & 3.460 & Sim & & & & Sim & & $\mathrm{Sim}$ & Sim & & & & \\
\hline Suécia & 3.303 & & Sim & & & Sim & Sim & & Sim & & & & \\
\hline Austria & 3.124 & & Sim & & & Sim & & $\mathrm{Sim}$ & Sim & & & & \\
\hline Finlândia & 2.450 & Sim & & & & Sim & $\mathrm{Sim}$ & & Sim & & & & \\
\hline Tchecoslováquia & - & Sim & & & & Sim & & Sim & Sim & & & & Sim \\
\hline Israel & - & Sim & & & & Sim & & Sim & Sim & & & & \\
\hline Noruega & - & Sim & & & & Sim & & Sim & Sim & & & & \\
\hline Africa do Sul ${ }^{5}$ & - & Sim & & Sim & Sim & Sim & Sim & & Sim & & Sim & & \\
\hline
\end{tabular}

1 Em dois estados o preço do lette de mercado è acertado segundo sua composição

2 Para leite fluido

3 Para derivados.

4 Vana entre os laticinios

50 pagamento varia entre um preço por volume e um moderno sistema de pagamento baseado num padrāo de litros

Fonte: International Dairy Federation Bulletin, 1995, e elaboraçāo pela autora 
Segundo este quadro, doze paises expressam o preço do seu leite em termos do volume; sete deles em termos do peso dos sólidos, e somente Polônia e África do Sul tomam como referência para o preço do leite outros componentes.

Quanto à forma de pagamento, o quadro 2 mostra que metade dos países configurados, entre eles Austrália, Canadá, França, Reino Unido, Nova Zelândia e Estados Unidos adotam, voluntariamente, o pagamento diferenciado sobre os componentes do leite (gordura, proteina, sólidos e sólidos não engordurados). A outra metade adota como base a forma regulatória. Somente a Austrália adota ambas as formas. Neste pais, o preço por componentes do leite é determinado pela indústria, ao passo que o preço do leite fluido, destinado ao mercado, é regulado pelo governo.

A terceira parte do quadro 2 permite observar que em todos os paises se paga pela gordura contida no leite (variando o limite minimo percentual de 3 a $4 \%$ ). Os demais componentes são praticamente irrelevantes em termos de pagamento por qualidade.

Um importante critério de pagamento por qualidade é o aspecto higiene. A exceção é a Índia, onde embora o leite fora dos padrões higiênicos seja rejeitado pela indústria, o pagamento ainda não está relacionado aos critérios de qualidade higiênica. Quase todos os Países observados consideram este critério, sendo que em alguns a decisão é voluntária por parte da indústria, e em outros é regulada por legislação.

A qualidade higiênica, a contagem total de bactérias (CTB) e a contagem de células somáticas (CCS) são critérios avaliados em quase todos os paises observados no quadro 3. Somente Alemanha, Índia e Quênia não premiam a qualidade do leite em virtude da CCS e CTB, e a Austrália não premia pagamentos segundo a CCS. 
Quadro 3: Pagamentos por qualidade em higiene em diferentes paises

\begin{tabular}{|c|c|c|c|c|c|c|c|c|c|c|c|c|c|c|c|c|c|c|c|}
\hline \multirow[t]{2}{*}{ Pais } & \multirow{2}{*}{$\begin{array}{c}\text { ol Produçã } \\
(1.000 t) \\
\text { *Fonte: CNA } \\
1998\end{array}$} & \multicolumn{7}{|c|}{ Pagamentos sobre a qualidade em higiene } & \multicolumn{11}{|c|}{ Pagamentos baseados em outros critérios } \\
\hline & & $\begin{array}{c}\text { Incluido } \\
\text { ou nāo }\end{array}$ & $\begin{array}{c}\text { Volun- } \\
\text { tário }\end{array}$ & $\begin{array}{l}\text { Legis- } \\
\text { lação }\end{array}$ & $\begin{array}{c}\text { Total } \\
\text { bact } / \mathrm{ml}\end{array}$ & $\begin{array}{c}\mathrm{CCS} \\
\mathrm{N}^{\circ} \cdot / \mathrm{ml}\end{array}$ & $\begin{array}{l}\text { Organol } \\
\text { qualidad }\end{array}$ & $\begin{array}{c}\text { Propriedade } \\
\text { macrosc. }\end{array}$ & $\begin{array}{l}\text { Inibidor } \\
\text { antibiót. }\end{array}$ & $\begin{array}{c}\text { resist. } \\
\text { bactéria } \\
\text { ao calor }\end{array}$ & $\begin{array}{c}\text { Psychot. } \\
\text { bact. }\end{array}$ & $\begin{array}{l}\text { Staph } \\
\text { aureus }\end{array}$ & $\begin{array}{c}\text { Salmo- } \\
\text { nella }\end{array}$ & $\begin{array}{c}\text { Listeria } \\
\text { monocyt. }\end{array}$ & $\begin{array}{l}\text { Strepto- } \\
\text { coccus }\end{array}$ & $\begin{array}{c}\text { E. coli } \\
\text { coliform }\end{array}$ & $\begin{array}{l}\text { Crios } \\
\text { copia }\end{array}$ & Outro & $\begin{array}{c}\text { Temp } \\
\text { leite } \\
\text { (coleta) }\end{array}$ \\
\hline Estados Unidos & 71375 & $\mathrm{Sim}$ & Sim & & Sim & Sim & & & Sim & & & & & & & & $\operatorname{sim}$ & & Sim \\
\hline India $^{4}$ & 35600 & & & & & & & & & & & & & & & & & & \\
\hline Alemanha ${ }^{1}$ & 28500 & Sim & & Sim & & & & & Sim & & & & & & & & $\mathrm{Sim}$ & Sim & $\mathrm{Sim}$ \\
\hline França & 24700 & Sim & Sim & Sim & $\operatorname{Sim}$ & Sim & & & Sim & & & Opt. & & Opt. & & & Sim & & Sim \\
\hline Brasil & 20800 & & $\mathrm{Sim}$ & & & & & Sim & & & & & & & & & & & Sim \\
\hline Reino Unido & 14600 & Sim & Sim & & Sim & Sim & & & Sim & & & & & & & & Sim & Opt & Sim \\
\hline Polónia & 12100 & Sim & & Sim & Sim & Sim & Sim & & Sim & & & & & & & & & & \\
\hline Nova Zelândia & 11640 & Sim & Sim & & Sim & Sim & $\mathrm{Sim}$ & $\mathrm{Sim}$ & Sim & & & & & & & & Sim & & Sim \\
\hline Holanda & 11200 & Sim & Não & Sim & Sim & Sim & Sim & Sim & Sim & & & & & & & & Sim & & Sim \\
\hline Austrália & 9656 & Sim & & Sim & Sim & & Sim & Sim & Sim & & & & & & & & Sim & Sim & Sim \\
\hline Japão & 8550 & Sim & Sim & & Sim & Sim & & & $\mathrm{Sim}$ & & & & & & & & Sim & & Sim \\
\hline Canada & 8200 & Sim & & Sim & Sim & Sim & Sim & Sim & Sim & Sim & Opt. & & Opt. & & & & Sim & Opt. & Sim \\
\hline Irlanda & 5681 & Sim & $\mathrm{Sim}$ & & Sim & Sim & & & $\mathrm{Sim}$ & Sim & & & & & & & Sim & $\mathrm{Sim}^{2}$ & Sim \\
\hline Dinamarca & 4660 & Sim & & $\mathrm{Sim}$ & $\mathrm{Sim}$ & Sim & Sim & & Sim & & & & & & & & Sim & & \\
\hline Bélgica & 3460 & Sim & & Sim & Sim & Sim & & Sim & Sim & & & & & & & $\mathrm{Sim}^{3}$ & $\mathrm{Sim}$ & & \\
\hline Suécia & 3303 & Sim & Sim & & Sim & Sim & Sim & & Sim & & & & & & & & Sim & & \\
\hline Austria & 3124 & Sim & & Sim & Sim & Sim & & & Sim & & & & & & & & Sim & & \\
\hline Finlândia & 2450 & Sim & Sim & & Sim & Sim & Sim & & $\mathrm{Sim}$ & & & Opt. & Opt. & Opt. & Opt & Opt. & Sim & & $\mathrm{Sim}$ \\
\hline Tchecoslováqui & - & Sim & & $\mathrm{Sim}$ & Sim & Sim & & & Sim & Sim & $\mathrm{Sim}$ & & & & & Sim & $\mathrm{Sim}$ & & Sim \\
\hline Israel & - & $\mathrm{Sim}$ & & $\mathrm{Sim}$ & Sim & $\mathrm{Sim}$ & Sim & & Sim & & & & & & & & $\mathrm{Sim}$ & & Sim \\
\hline Quénia & - & Sim & Sim & & & & & & & & & & & & & & & & \\
\hline Noruega & - & Sim & & $\mathrm{Sim}$ & Sim & $\mathrm{Sim}$ & Sim & & Sim & & & & & & & & Sim & & \\
\hline Africa do Sul & - & Sim & Sim & $\operatorname{Sim}$ & Sim & Sim & & & Sim & & & & & & & & Sim & & Sim \\
\hline
\end{tabular}

1 Padrões de qualidade sequndo o conjunto proposto na CEE - Diretive 85/397

2 Metais pesados

3 Somente leite AA (qualidade especial)

4 Leite fora dos padroes de higiene é rejeitado pelas indústrias mas o pagamento ainda nåo está relacionado com qualidade em higiene

Fonte: International Dairy Federation Bulletin, 1995, e elaboraçāo pela autora. 
As propriedades organolépticas e macroscópicas do produto são outros aspectos avaliados, muito embora sejam premiadas como pagamento por qualidade higiênica do leite apenas na Austrália, Canadá, Holanda e Nova Zelândia. A preocupação também com os aspectos físicos do leite nestes Países se deve ao fato de que eles são os principais Paises exportadores de leite, portanto, sofrem um controle maior sobre a qualidade do produto.

A presença de antibióticos e inibidores, bem como de algumas das mais comuns bactérias encontradas no leite também são objetos de avaliação nos sistemas de pagamentos por qualidade, entretanto não são muito comuns. A crioscopia e a temperatura (ou frio) do leite no momento de captação também são outros dois aspectos considerados. Além destes já citados, outros componentes são praticamente irrelevantes para efeito de pagamento.

Especificamente sobre a contagem total de bactérias, os padrões de classes aceitáveis, rejeição e freqüência dos testes, nos diversos Paises são apresentados na quadro 4. Pela mesma percebe-se que os padrões mais rigorosos de aceitação e rejeição estão nos Estados Unidos, Austrália, Canadá, Dinamarca, Holanda e Reino Unido. Na Polônia, o teste quinzenal apenas analisa a amostra do leite coletado através do resultado positivo ou negativo da redutase.

O quadro 5 mostra os padrões para a contagem de células somáticas contidas no leite, bem como o nível a partir do qual se rejeita o produto e a freqüência das análises. Estes dois últimos quadros, 5 e 6 , mostram nas subcolunas dentro da segunda coluna, os niveis, em ordem decrescente, da esquerda para direita, para os quais os pagamentos por qualidade são reconhecidos e avaliados, até o nivel em que não mais se premia e passa-se a rejeita o produto. 
Quadro 4: Contagem de bactérias - padröes por classes

\begin{tabular}{|c|c|c|c|c|c|c|c|c|c|}
\hline \multirow{2}{*}{\begin{tabular}{|c|} 
Pais \\
\\
Estados Unidos \\
\end{tabular}} & \multirow{2}{*}{\begin{tabular}{|c|} 
Vol. Produçã \\
$(1,000 t)$ \\
*Fonte: CNA \\
1998 \\
71375 \\
\end{tabular}} & \multicolumn{6}{|c|}{ Categorias de classes (cont. total de bactérias x 1000) } & \multirow{2}{*}{\begin{tabular}{|c|} 
Limite de rejeição \\
300 \\
\end{tabular}} & \multirow{2}{*}{$\begin{array}{l}\text { Frequência (e expressão do resultado) } \\
1 \times / m e ̂ s \\
\end{array}$} \\
\hline & & $<25$ & $>25$ & & & & & & \\
\hline Alemanha & 28500 & $<100$ & $100-400$ & $>400$ & & & & & \\
\hline França & 24700 & $<50$ & $50-100$ & $100-300$ & $>300$ & & & 500 & 3 x/mês \\
\hline Reino Unido & 14600 & $<20$ & $20-100$ & $>100$ & & & & 200 & semanalmente \\
\hline Polônia & 12100 & & & & & & & & $2 \times /$ mês \\
\hline Nova Zeländia & 11640 & $<25$ & $25-50$ & $50-100$ & $100-200$ & $200-500$ & $>500$ & & $1 \times / 10$ dias \\
\hline Holanda & 11200 & $<100$ & $100-250$ & $>250$ & & & & & $1 \times / 2$ meses \\
\hline Austrália & 9656 & $<20$ & $20-50$ & $>50$ & & & & 50 & $2-4 \times /$ mês \\
\hline Japāo & 8550 & $<300$ & $>300$ & & & & & 1000 & $1 \mathrm{x} / \mathrm{més}$ \\
\hline Canada & 8200 & $<50$ & $50-75$ & $>75$ & & & & 100 & $1 \times /$ mès \\
\hline Irlanda & 5681 & $<30$ & $30-50$ & $50-100$ & $100-250$ & $250-500$ & & 500 & $2 \times /$ mês \\
\hline Dinamarca & 4660 & $<30$ & 30-100 & $100-300$ & $>300$ & & & $400^{2}$ & semanalmente \\
\hline Bélgica & 3460 & $<100$ & $100-300$ & $300-400$ & $1 x>400$ & $2 x>400$ & $3 x>400$ & - & 2 x/mês (média geométrica de 2 meses) \\
\hline Suécia & 3303 & $<100$ & $100-300$ & $>300$ & & & & & 2 x/mês (caso haja resultado ruim após classificaçāo $4 \times /$ mês) \\
\hline Austria & 3124 & $<100$ & $100-300$ & $300-600$ & $600-1000$ & $>1000$ & & - & $2 x /$ més \\
\hline Finlândia & 2450 & $<50$ & $50-100$ & $100-250$ & $>250$ & & & 500 & $2 \times /$ mês \\
\hline Tchecoslováquia & - & $<100$ & $100-300$ & $300-800$ & $800-2000$ & & & 800 & $2 \times /$ mès \\
\hline Israel & - & $<40$ & $40-100$ & $100-250$ & $250-500$ & $>500$ & & & $3 \mathrm{x} / \mathrm{més}$ (classific. segundo a soma dos 3 últimos resultados) \\
\hline Noruega & - & $<30$ & $30-80$ & $80-300$ & $>300$ & & & 300 & $3 \times /$ mês \\
\hline Africa do Sul & - & $<50$ & $50-200$ & $200-300$ & $>300$ & & & 300 & $3 \mathrm{x} / \mathrm{mès}$ \\
\hline
\end{tabular}

1 Recomendaçoes a partir do final de 1993

2 De acordo com Diretiva - CEE (média geométrica de 3 meses)

Fonte: International Dairy Federation Bulletin, 1995, e elaboração pela autora. 
Quadro 5: Contagem de células - padrões segundo niveis de classes

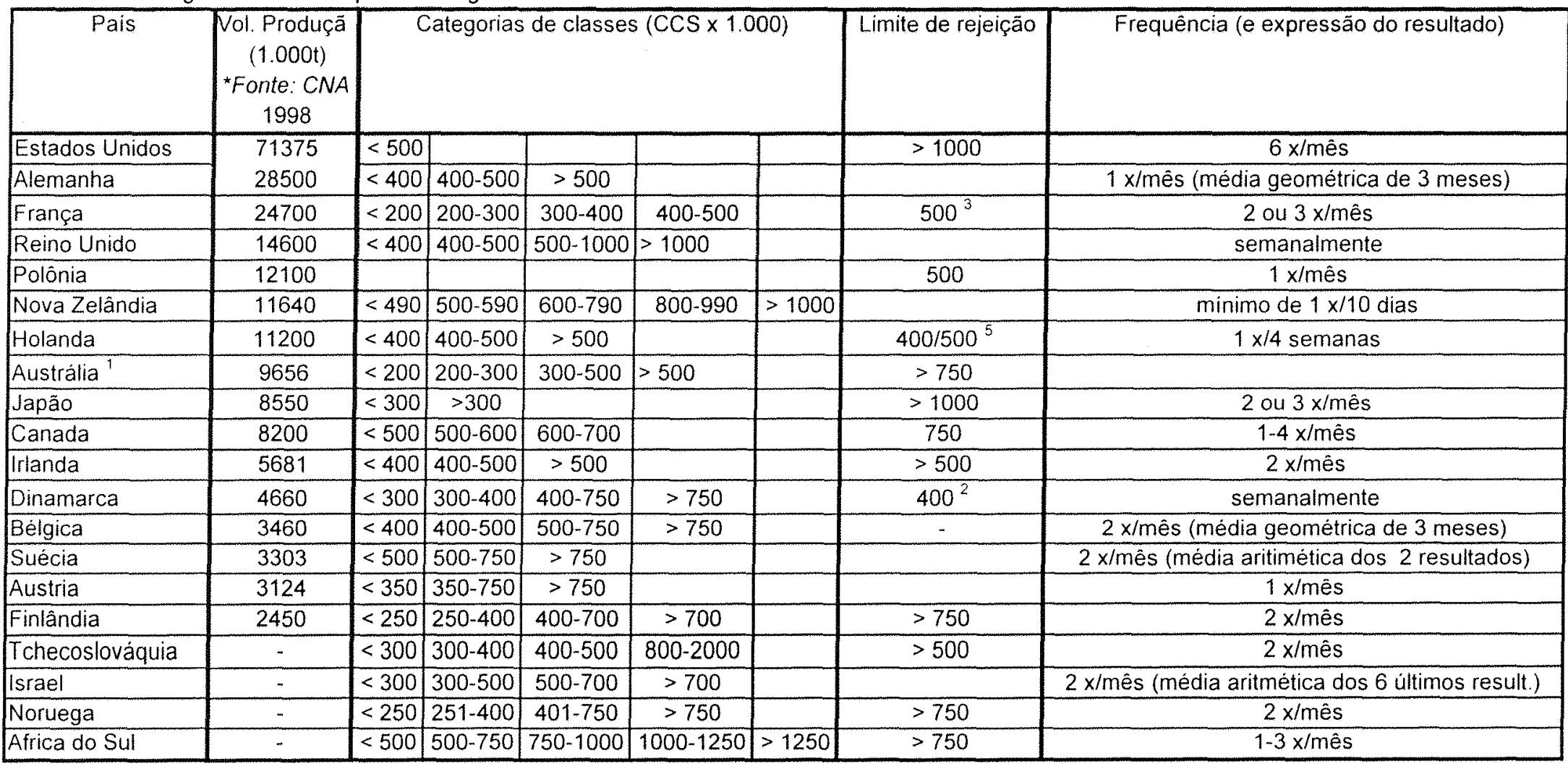

1 Recomendações a partir do final de 1993.

${ }^{2}$ De acordo com Diretiva - CEE, baseado na média geométrica

$3<500$ até primeiro de janeiro 1998 , a partir de então $<400$, de acordo com a Diretiva - CEE

${ }^{4}$ Sistema de classificação de uma indústria, Outras usam 500.000 ou 750,000 para classificarem o leite

O limite de rejeição $>750.000$ é usado por alguns paises, mas a maioria não o usa.

${ }^{5}$ Depende do uso final do leite, < 400 desde 1 Janeiro 1998, de acordo com CEE-directive, baseado na média geometrica

Fonte: International Dairy Federation Bulletin, 1995, e elaboração pela autora. 
Quadro 6: Preço ao produtor e responsabilidade pela análise do leite nos diferentes paises

\begin{tabular}{|c|c|c|c|c|c|c|c|c|c|}
\hline \multirow[t]{2}{*}{ Pais } & \multirow{2}{*}{\begin{tabular}{|c|} 
Vol. Produçã \\
$(1.000 t)$ \\
$\times$ Fonte: CNA \\
1998 \\
\end{tabular}} & \multicolumn{2}{|c|}{$\begin{array}{c}\text { Preço ao produtor }{ }^{7} \\
\text { Transporte e outros custos }\end{array}$} & \multicolumn{6}{|c|}{ Quem analisa o leite? } \\
\hline & & Exclui & Inclui & $A$ indústria & $\begin{array}{c}\text { Organiza. } \\
\text { profiss. }\end{array}$ & $\begin{array}{l}\text { Organiz. } \\
\text { interprof. }\end{array}$ & $\begin{array}{l}\text { Corpo } \\
\text { público }\end{array}$ & $\begin{array}{c}\text { Organiz. } \\
\text { ndep ou priv } \\
\end{array}$ & $\begin{array}{l}\text { Organ. } p / \\
\text { disputas }\end{array}$ \\
\hline Estados Unidos & 71375 & Sim & & Sim & Sim & & & $\mathrm{Sim}$ & \\
\hline India & 35600 & Sim & & Sim & Sim & & & & $\mathrm{Sim}$ \\
\hline Alemanha & 28500 & & Sim & & Sim & & & & Sim \\
\hline Franca & 24700 & Sim & & & & $\operatorname{Sim}$ & & & Sim \\
\hline Reino Unido & 14600 & Sim & & & $\mathrm{Sim}^{3}$ & & & & $\operatorname{Sim}^{3}$ \\
\hline Polônia & 12100 & Sim & & Sim & & & & & \\
\hline Nova Zelàndia & 11640 & & Sim & Sim & $\operatorname{Sim}^{5}$ & & & & Sim \\
\hline Holanda & 11200 & & Sim & & & & & Sim & Sim \\
\hline Austrália & 9656 & $\mathrm{Sim}$ & & $\mathrm{Sim}$ & & & & & Sim \\
\hline Japão & 8550 & & Sim & & & & Sim & Sim & \\
\hline Canada & 8200 & $\mathrm{Sim}$ & & & & Sim & Sim & Sim & $\mathrm{Sim}$ \\
\hline Irlanda & 5681 & & $\mathrm{Sim}$ & Sim & & & & & Sim \\
\hline Dinamarca & 4660 & $\mathrm{Sim}$ & & & & & & $\mathrm{Sim}$ & \\
\hline Bélgica & 3460 & & Sim & & & $\mathrm{Sim}$ & & & Sim \\
\hline Suécia & 3303 & & Sim & & & & & Sim & \\
\hline Austria & 3124 & Sim & & & & $\operatorname{sim}$ & & & Sim \\
\hline Finlândia & 2450 & & Sim & Sim & Sim & & & & \\
\hline Tchecoslováquia & - & $\operatorname{sim}$ & & $\operatorname{sim}$ & & $\operatorname{sim}^{2}$ & & & \\
\hline Israel & - & & Sim & Sim & $\operatorname{Sim}^{4}$ & & & & Sim \\
\hline Quênia & + & $\mathrm{Sim}$ & & $\mathrm{Sim}$ & & & & & \\
\hline Noruega & - & & Sim & Sim & & & & & \\
\hline Africa do Sul & - & $\operatorname{sim}^{6}$ & $\operatorname{Sim}^{6}$ & $\mathrm{Sim}$ & & & & & Sim \\
\hline
\end{tabular}

Procedimento de arbitragem facultativo

${ }^{2}$ Laboratórios centrais.

${ }^{3}$ Milk Marketing Boards.

${ }^{4}$ Somente para CCS.

${ }^{5}$ Varia entre as induistrias de laticinios.

"Alguns preços excluem outros incluem transporte.

${ }^{7}$ A definição de preço do leite ao produtor difere de pais para pais.

Fonte: International Dairy Federation Bulletin, 1995, e elaboraçāo pela autora. 
Assim como os sistemas de pagamento por qualidade do leite diferem nos vários Paises produtores no mundo, a formação do preço do produto e a responsabilidade das análises fica a cargo de diferentes membros nos respectivos Países.

Pelo quadro 6 vê-se que, em metade dos Países observados, o preço ao produtor inclui transporte e outros custos no preço do leite, a outra metade não inclui. Somente a África do Sul tem preços que incluem e que não incluem o transporte no custo do produto. Deve-se deixar claro também que a definição ou representação desses "preços ao produtor" difere de Pais para País.

Quanto à análise do leite, a responsabilidade geralmente é delegada às indústrias ou laticinios, organizações profissionais ou interprofissionais, corpo público, organismos privados independentes, ou organismos para disputas. Este últimos normalmente são utilizados em casos de desacordos entre produtor e indústria em relação ao resultado da análise feita por algum dos outros órgãos no respectivo País.

Assim como a formação de preços e a responsabilidade das análises da qualidade do leite são determinadas diferentemente entre os vários Paises, a determinação do preço base e do diferencial de preços também o são. Entretanto, o quadro 7 , mostra que, notavelmente na maioria dos paises observados são as próprias indústrias quem ditam o preço base, bem como o diferencial. Apenas no Canadá, o mercado é determinante de diferenciais no preço do leite. A intervenção das autoridades públicas se dá normalmente quando a questão ou é o controle de qualidade, ou em caso de negociações com produtores ou sobre o preço de derivados do leite.

A forma como os preços do leite e de seus derivados são determinados, regulamentados (preço base) ou negociados em cada País é o determinante direto dos sistemas de pagamento utilizados e, por conseguinte, das relações contratuais entre produtor e indústria. Os detalhes dos contratos entre estes 
Quadro 7: Responsabilidades sobre o preco base e os determinantes dos diferenciais de preco praticados nos diferentes paises

\begin{tabular}{|c|c|c|c|c|c|c|c|c|c|c|}
\hline \multirow[t]{2}{*}{ Pais } & \multirow{2}{*}{$\begin{array}{c}\text { Vol. Produção } \\
\text { (1.000t) } \\
\text { *Fonte: CNA } \\
1998\end{array}$} & \multicolumn{4}{|c|}{ Quem determina o preço base? } & \multicolumn{5}{|c|}{ Quem determina os diferenciais de preços? } \\
\hline & & A indústria & $\begin{array}{c}\text { Organ. } \\
\text { profission. }\end{array}$ & $\begin{array}{c}\text { Organiz. } \\
\text { interprofiss. }\end{array}$ & $\begin{array}{l}\text { Autoridade } \\
\text { pública }\end{array}$ & A indústria & $\begin{array}{l}\text { Organiz. } \\
\text { profission. }\end{array}$ & $\begin{array}{l}\text { Organ. } \\
\text { interprof. }\end{array}$ & $\begin{array}{l}\text { Autoridade } \\
\text { pública }\end{array}$ & Marketing \\
\hline Estados Unidos & 71375 & Sim & & & & Sim & & & & \\
\hline Éndia & 35600 & Sim & Sim & & & Sim & Sim & & & \\
\hline Alemanha & 28500 & Sim & & & & Sim & & & & \\
\hline Franca & 24700 & Sim & & Sim & & Sim & & Sim & & \\
\hline Brasil & 20800 & Sim & & & & Sim & & & & \\
\hline Reino Unido & 14600 & & $\operatorname{Sim}^{6}$ & & & & $\operatorname{Sim}^{5}$ & & & \\
\hline Polónia & 12100 & Sim & & & & $\operatorname{sim}$ & & & & \\
\hline Nova Zelândia & 11640 & Sim & & & & Sim & & & & \\
\hline Holanda & 11200 & $\mathrm{Sim}$ & & & & Sim & & Sim & & \\
\hline Austrália & 9656 & & & & Sim & & & & Sim & \\
\hline Japão & 8550 & & & $\operatorname{sim}^{8}$ & $\operatorname{Sim}^{9}$ & & & Sim & & \\
\hline Canada & 8200 & & & $\operatorname{sim}^{3}$ & $\operatorname{sim}$ & & & $\operatorname{sim}$ & Sim & Sim \\
\hline Irlanda & 5681 & Sim & & & & $\operatorname{Sim}^{7}$ & & & & \\
\hline Dinamarca & 4660 & & Sim & & & & $\operatorname{Sim}^{1}$ & & $\operatorname{sim}^{2}$ & \\
\hline Belgica & 3460 & $\operatorname{sim}$ & & & & & & & $\mathrm{sim}$ & \\
\hline Suécia & 3303 & Sim & & & & Sim & & & & \\
\hline Austria & 3124 & & & & $\sin$ & & & & Sim & \\
\hline Finlāndia & 2450 & & & $\operatorname{sim}^{5}$ & $\operatorname{sim}^{5}$ & Sim & & & & \\
\hline Tchecoslováquia & - & Sim & & & & Sim & & & & \\
\hline Israel & - & & $\mathrm{Sim}$ & & Sim & & Sim & & Sim & \\
\hline Austrália (B) & & Sim & & & & $\mathrm{Sim}$ & & & & \\
\hline Quênia & $z$ & Sim & & & & Sim & & & & \\
\hline Noruega & $=$ & Sim & & & & & & & Sim & \\
\hline Africa do Sul & - & $\mathrm{Sim}$ & & & & $\operatorname{sim}$ & & & & \\
\hline
\end{tabular}

Composiçăo

2 Qualidade.

${ }^{3}$ Canadian Dairy Commission.

4 Regres especificas.

${ }^{5}$ Negociado entre o governo e Uniăo Nacional dos Produtores.

Milk Marketing Boards

7 Padrões da CEE e padróes nacionais

${ }^{8}$ Para leite fluido

Para derivados lácteos.

Fonte: International Dairy Federation Bulletin, 1995, e elaboração pela autora. 
agentes e os princípios básicos dos sistemas de pagamento nos diferentes países são apresentados no quadro 8.

A refrigeração do leite já é prática consensual em todos os Países desenvolvidos do mundo. Apenas produtores da Índia e do Quênia não resfriam seu leite na propriedade. Pelo quadro 9 pode-se ver que a temperatura média de resfriamento do leite é de $4^{\circ} \mathrm{C}$, principalmente nos Paises onde a coleta é feita em dias alternados. Mas temperatura de 6 a $10^{\circ} \mathrm{C}$ também é aceita em algumas regiões onde a coleta é feita diariamente.

A propriedade dos tanques resfriadores do leite normalmente cabe aos produtores. Somente na Nova Zelândia, na Noruega e na Suécia a propriedade dos tanques cabe à indústria de derivados. Na França, Finlândia, Holanda e África do Sul há tanques sendo utilizados sob as duas formas de apropriamento. No Reino Unido, onde o Milk Marketing Board é o responsável pela coordenação e organização de todo o sistema de produção, transporte, processamento e distribuição do leite, $90 \%$ dos tanques de resfriamento do leite são de propriedade desta organização.

Nestes Países, como o resfriamento do leite imediatamente após a ordenha é uma norma comum do sistema de qualidade adotado, prêmios por resfriamento do leite não são pagos. E quando o são representam uma forma de estimular novos produtores a entregarem seu leite frio. Outro motivo é homogeneizar o resfriamento do leite em todo o País, como é o caso de Alemanha, Checoslováquia, Holanda e África do Sul, onde algumas regiões ainda não estão plenamente engajadas nos critérios de classificação da qualidade do leite.

Ao contrário de prêmios, em Israel, produtores que não entregam seu leite resfriado são penalizados. Na África do Sul, entretanto, alguns laticínios pagam um preço maior pelos componentes do leite (gordura, baixo nível de células somáticas e de contagem total de bactérias) caso ele esteja resfriado. 


\begin{tabular}{|c|c|c|c|c|c|c|c|c|c|c|c|c|c|c|}
\hline \multirow[t]{2}{*}{ País } & \multirow{2}{*}{\begin{tabular}{|c|} 
ol. Produçă \\
(1.000t) \\
*Fonte: CNA \\
1998
\end{tabular}} & \multirow{2}{*}{$\begin{array}{c}\text { Existência } \\
\text { de } \\
\text { contratos }\end{array}$} & \multicolumn{4}{|c|}{$\begin{array}{c}\text { Contratos entre indústria e } \\
\text { respectivos produtores }\end{array}$} & \multicolumn{6}{|c|}{ Quantas vezes o produtor é pago? } & \multicolumn{2}{|c|}{ Frequência e princípios de suplementaçōes } \\
\hline & & & Preços & Volume & emper & Qualid & $\begin{array}{c}\text { Após } \\
\text { cada } \\
\text { entrega }\end{array}$ & $\begin{array}{l}\text { A cada } \\
\text { eman }\end{array}$ & $\begin{array}{c}\text { A cada } \\
10 \\
\text { dias }\end{array}$ & $\begin{array}{c}\text { A cada } \\
15 \\
\text { dias } \\
\end{array}$ & $\begin{array}{c}\text { A cada } \\
\text { mês }\end{array}$ & $\begin{array}{c}\text { Pagamento } \\
\text { a } \\
\text { prestaçäo }\end{array}$ & $\begin{array}{c}\text { Pagos } \\
\text { mensalmente }\end{array}$ & $\begin{array}{c}\text { Pagos } \\
\text { anualmente }\end{array}$ \\
\hline Estados Unidos & 71375 & & & & Sim & & & & & Sim & & & & \\
\hline India & 35600 & Sim & Sim & & & & Sim & & Sim & & & & & \\
\hline Alemantia & 28500 & Sim & Sim & Sim & $\mathrm{Sim}$ & Sim & & & & & Sim & & & Sim \\
\hline Franca & 24700 & Sim & Sim & Sim & Sim & & & & & & Sim & Sim & Sim & Sim \\
\hline Brasil & 20800 & & & & & & & & & & Sim & & $\operatorname{sim}$ & $\mathrm{Sim}$ \\
\hline Reino Unido & 14600 & Sim & Sim & Sim & & & & & & & $\mathrm{Sim}$ & Sim & & Sim \\
\hline Polónia & 12100 & Sim & Sim & Sim & & & & & & & $\mathrm{Sim}$ & & & \\
\hline Nova Zelândia & 11640 & $\operatorname{sim}$ & Sim & $\operatorname{Sim}^{6}$ & $\mathrm{Sim}$ & & & & & & $\operatorname{sim}$ & Sim & $\mathrm{Sim}$ & Sim \\
\hline Holanda & 11200 & $\operatorname{sim}$ & $\mathrm{Sim}$ & $\operatorname{sim}$ & & & & & & $\operatorname{sim}^{3}$ & & Sim & & Sim \\
\hline Austrália 1 & 9656 & & & Sim & & & & & & & Sim & & & \\
\hline Japāo & 8550 & Sim & Sim & Sim & Sim & & & & & & $\mathrm{Sim}$ & & & \\
\hline Canada & 8200 & Sim & $\mathrm{Sim}$ & Sim & $\mathrm{Sim}$ & & & & & $\operatorname{Sim}^{5}$ & $\operatorname{Sim}$ & & & \\
\hline Irlanda & 5681 & & & & & & & & & & Sim & & & \\
\hline Dinamarca & 4660 & & & & & & & & & $\mathrm{Sim}^{3}$ & & Sim & & Sim \\
\hline Bélgica & 3460 & & & & & & & & & $\operatorname{Sim}^{9}$ & Sim & Sim & Sim & $\mathrm{Sim}^{2}$ \\
\hline Suécia & 3303 & $\mathrm{Sim}$ & & Sim & & & & & & & $\mathrm{Sim}$ & Sim & & sim \\
\hline Austria & 3124 & & & & & & & & & & $\mathrm{Sim}$ & & & \\
\hline Finlândia & 2450 & & & & & & & & & & Sim & Sim & & Sim \\
\hline Tchecoslováquia & - & $\mathrm{Sim}$ & & Sim & & & & & & & Sim & Sim & Sim & \\
\hline Israel & - & & & & & & & Sim & & & & Sim & $\mathrm{Sim}$ & \\
\hline Quénia & - & & & & & & & & & & Sim & & & \\
\hline Noruega & $=$ & & & & & & & & & & Sim & & & \\
\hline Africa do Sul & $=$ & Sim/Năo ${ }^{8}$ & Sim & Sim & & & & & & & Sim & & & \\
\hline
\end{tabular}

Quotas de mercado sắo designadas aos produtores em alguns estados

2 Algumas indústrias pagam suplementos aos produtores ao final do ano de acordo com a suscetibilidade do mercado.

${ }^{3}$ De duas em duas semanas ou em 14 dias.

4 Valor básico.

5 Adiantado e no pagamento final no fim do més.

${ }^{5}$ Aplicado independente da oferta de contrato sazonal.

'Algumas industrias tém contratos.

Algumas indüstrias tém um sistema de quota/participaçăo como contrato e outras não

- Alguns laticinios na Bélgica pagam aos produtores a cada 15 dias.

Fonte: International Dairy Federation Bulletin, 1995, e elaboração pela autora 
Quadro 9: Aspectos do transporte e refrigeração de leite praticados nos diferentes paises.

\begin{tabular}{|c|c|c|c|c|c|c|c|c|c|c|c|c|c|c|}
\hline \multirow[t]{2}{*}{ Pais } & \multirow{2}{*}{$\begin{array}{c}\text { Vol.Produça } \\
\text { (1.000t) } \\
\text { *Fonte: CNA } \\
1998\end{array}$} & \multicolumn{3}{|c|}{ Transporte de lelte } & \multicolumn{4}{|c|}{ Deduçáo por transporte feito } & \multicolumn{2}{|c|}{ Refrigeraçāo } & \multicolumn{4}{|c|}{ Propriedade do tanque de restriamento } \\
\hline & & $\begin{array}{c}\text { Produ- } \\
\text { tor }\end{array}$ & $\begin{array}{c}\text { Indus } \\
\text { tria }\end{array}$ & Outros & $\begin{array}{l}\text { Pagamento } \\
\text { deduzido } \\
\text { pela indús. }\end{array}$ & $\begin{array}{c}\text { Por } \\
\text { volume }\end{array}$ & $\begin{array}{l}\text { Por } \\
\text { peso }\end{array}$ & $\begin{array}{c}\text { Por } \\
\text { carre- } \\
\text { mento }\end{array}$ & $\begin{array}{l}\text { Refrigerad } \\
\text { na fazenda }\end{array}$ & $\begin{array}{c}\text { Temper } \\
\left({ }^{\circ} \mathrm{C}\right)\end{array}$ & Produtor & $\begin{array}{c}\text { Indús- } \\
\text { tria }\end{array}$ & $\begin{array}{l}\text { Organ. } \\
\text { Profiss. }\end{array}$ & 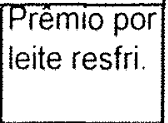 \\
\hline Estados unidos & 77.375 & & $\operatorname{sim}$ & & $\operatorname{Sim}$ & & Sim & $\operatorname{Sim}$ & Sim & $<7^{\circ} \mathrm{C}$ & $\operatorname{sim}$ & & & \\
\hline India & 35.600 & & Sim & & & & & & & & & & & \\
\hline Alemanha & 28.500 & & Sim & & & & & & Sim & $<8^{\circ} \mathrm{C}$ & Sim & & & \\
\hline França & 24.700 & & $\operatorname{Sim}$ & $\operatorname{sim}$ & & & & & Sim & $2-4^{\circ} \mathrm{C}$ & Sim & $\operatorname{Sim}$ & & Sim \\
\hline Brasil & 20800 & $\mathrm{Sim}$ & & & & & & & & & & & & \\
\hline Reino Unido & 14.600 & & & $\operatorname{Sim}^{4}$ & & & & & Sim & $<4,5^{\circ} \mathrm{C}$ & Sim & & $\operatorname{Sim}^{5}$ & \\
\hline Polônia & 12.100 & $\operatorname{Sim}$ & $\mathrm{Sim}$ & & & & & & Sim & $\angle 4^{\circ} \mathrm{C}$ & Sim & & & \\
\hline Nova Zelándia & 11.640 & & $\operatorname{Sim}$ & & $\operatorname{sim}$ & $\operatorname{sim}$ & & & Sim & $<7^{\circ} \mathrm{C}$ & & $\operatorname{sim}$ & & \\
\hline Holanda & 11.200 & & $\operatorname{Sim}$ & & Sim & Sim & & Sim & Sim & $0-4^{\circ} \mathrm{C}$ & Sim & Sim & & 7 \\
\hline Austrália & 9.656 & & $\operatorname{sim}$ & & $\operatorname{Sim}$ & $\operatorname{Sim}$ & & & $\operatorname{Sim}$ & $<5^{\circ} \mathrm{C}$ & Sim & & & \\
\hline Japăo & 8.550 & & Sim & $\sin$ & $\operatorname{sim}$ & & $\operatorname{Sim}$ & & $\sin$ & $3-4^{\circ} \mathrm{C}$ & $\operatorname{sim}$ & & & \\
\hline Canada & 8.200 & Sim & $\operatorname{Sim}$ & $\mathrm{Sim}^{2}$ & Sim & Sim & & & Sim & $<4^{\circ} \mathrm{C}$ & Sim & & & \\
\hline Trlanda & 5.681 & Sim & $\mathrm{Sim}$ & & Sim & Sim & & Sim & Sim & $\angle 4^{\circ} \mathrm{C}$ & $\mathrm{Sim}$ & & & $\operatorname{Sim}$ \\
\hline Dinamarca & 4.660 & & Sim & & $\operatorname{Sim}$ & & $\mathrm{Sim}$ & Sim & Sim & $4-6^{\circ} \mathrm{C}^{12}$ & $\mathrm{Sim}$ & & & \\
\hline Bélgica & 3.460 & & Sim & & & & & & Sim & $<4^{\circ} \mathrm{C}$ & Sim & & & \\
\hline Suécia & 3.303 & & Sim & & & & & & Sim & $<4^{\circ} \mathrm{C}$ & & $\operatorname{Sim}^{8}$ & & \\
\hline Austria & 3.124 & & Sim & & Sim & & Sim & & $\operatorname{Sim}$ & & Sim & & & \\
\hline Finlândia & 2.450 & & Sim & & & & & & Sim & $\angle 4^{\circ} \mathrm{C}$ & $\operatorname{Sim}$ & Sim & & \\
\hline Tchecoslováquia & - & Sim & $\mathrm{Sim}$ & & & & & & Sim & $4-7^{\circ} \mathrm{C}$ & Sim & & & 3 \\
\hline Israel & - & $\overline{S i m}$ & & & & & & & Sim & $2-4^{\circ} \mathrm{C}$ & $\overline{\operatorname{Sim}}$ & & & 6 \\
\hline Quênia & $=$ & & $\mathrm{Sim}$ & & $\operatorname{Sim}$ & Sim & & & & & & & & \\
\hline Noruega & - & & $\mathrm{Sim}$ & & $\mathrm{Sim}$ & Sim & & & Sim & $0-4^{\circ} \mathrm{C}$ & & Sim & & \\
\hline Africa do Sul & - & Sim & Sim & Sim & $\operatorname{sim} /$ Năo $^{9}$ & Sim & & Sim & Sim & $4-7^{\circ} \mathrm{C}$ & Sim & Sim & & Não/Sim ${ }^{10}$ \\
\hline
\end{tabular}

'Poucas indústrias pagam premio.

${ }^{2}$ Marketing Board

$3+1$ U U $\$ 0,02$ Aitro

$4 M B$ através de contratantes e próprios veiculos.

${ }^{5}$ MMB para Irlanda possui $90 \%$ tanques.

${ }^{6}$ Leite não resfriado é penalizado

Fonte: International Dainy Federation Bulletin, 1995, e elaboraçāo pela autora
7 Algumas indústrias pagam prêmio

${ }^{8} 95 \%$ dos tanques

${ }^{9}$ Algumas indüstrias incluem e outras excluem custos de transporte

${ }^{10}$ Algumas indústrias pagam um preço maior sobre os componentes do leite quando este

está restriado, outras não o fazem.

"Uma minoria de indústrias fazem deduçăo dos custos de transponte (fixo ao mês).

12 Coleta diária com leite à temperatura máxima de $6^{\circ} \mathrm{C}$ e em dias alternados no máximo $4^{\circ} \mathrm{C}$ 
Igualmente ao resfriamento, a responsabilidade pelo transporte do leite varia de país para país. Na grande maioria dos Países, as indústrias são as principais responsáveis. No Canadá e na África do Sul, tanto os produtores quanto as indústrias, ou outros agentes/organizações, encarregam-se do transporte do leite. Somente no Reino Unido, o transporte do leite frio e a granel é exclusividade de um outro agente, que não o produtor ou a indústria, que é o Milk Marketing Board.

Entre os Paises observados, $50 \%$ deles adotam contratos em suas transações de compra e venda de leite, a outra metade não os utiliza. Em alguns Paises, onde embora não existam contratos, as indústrias pagam um suplemento anualmente aos seus fornecedores, segundo a suscetibilidade do mercado. É o caso de Austrália, Bélgica, Dinamarca e Finlândia. Alemanha, França, Reino Unido, Holanda, Suécia e Nova Zelândia também pagam este suplemento anualmente, além de firmarem contratos ao longo do ano entre produtores e indústrias.

Os principais aspectos concernentes aos contratos são preço, volume, temperatura e qualidade do leite. A Austrália não adota formas contratuais explícitas, entretanto em alguns de seus Estados são definidas quotas para os produtores em função do seu volume entregue, sendo este o principal critério de comprometimento e de pagamento pela matéria-prima. Na Suécia, embora se utilize contrato entre produtor e indústria de leite, o volume também é o único critério observado nas transações. Na Checoslováquia, como na Suécia, além do volume também se paga pela qualidade do leite entregue.

A grande maioria dos Paises que seguem contratos na compra e venda de leite in natura observa os critérios de preço, volume e temperatura da matéria-prima. Apenas na Alemanha observa-se, além destes três, o critério qualidade. Israel e Estados Unidos não utilizam contratos mas fecham seus pagamentos com os produtores em função da qualidade do produto.

Como os principais critérios utilizados nos contratos são preço e volume, 
cabe ressaltar alguns efeitos sazonais sobre estes aspectos nos diferentes países. Pelo quadro 10, percebe-se que a estabilidade dos preços pagos ao produtor pode estar relacionada às variações sazonais de mercado ou fixa por um ano. Áustria, Austrália, Irlanda, Israel, Nova Zelândia e África do Sul, embora não sigam contratos previamente definidos (quadro 6), adotam um sistema de preços fixos para o leite ao longo de um ano.

É interessante observar que no caso de Áustria, Austrália e Israel o preço nem é uma variável relevante nos eventuais contratos que possam existir entre produtor e indústria. Na Nova Zelândia, a rigidez se deve ao fato de que o País tem $90 \%$ da sua produção de leite voltada às exportações, portanto os preços são praticamente fixos em função de acordos externos.

Em 16 dos 22 dos países, o preço não é fixo. Ele varia segundo oscilações sazonais e/ou do mercado de leite e de derivados. Uma parte da Austrália, Alemanha, Dinamarca e Holanda sofre instabilidade nos preços do leite em função de ambas variações. Na grande maioria dos outros Paises, a estabilidade dos preços está relacionada apenas às variações sazonais. Isto se explica pelo alto nivel de organização dos produtores presentes nestes Países e pelo controle do governo sobre a oferta e demanda do produto no mercado, impedindo assim que este determine flutuações bruscas nos preços do leite internamente.

Pelo quadro 10 também se pode observar que os períodos nos quais os preços do leite ao produtor atingem a maior alta é no outono e inverno ${ }^{16}$, ao passo que primavera e verão são as estações de baixa.

Há que se deixar claro, contudo, que a presença ou não de contrato bases nas negociações entre produtor e indústria de leite não significa que os termos dos contratos sejam os mesmos nos diferentes Países.

${ }^{16}$ A Checoslováquia também os tem na primavera. 
Quadro 10: Efeitos sazonais sobre o preço e volume de leite entregue aos laticinios nos diferentes paises

\begin{tabular}{|c|c|c|c|c|c|c|c|c|c|c|c|c|c|c|c|c|c|c|c|c|}
\hline \multirow[t]{4}{*}{ Pais } & \multirow{4}{*}{$\begin{array}{c}\text { Vol. Produçã } \\
\text { (1,000t) } \\
\text { *Fonte: CNA } \\
1998\end{array}$} & \multicolumn{19}{|c|}{ Sazonalidade } \\
\hline & & \multicolumn{3}{|c|}{ Estabilidade de preço } & \multicolumn{4}{|c|}{ Durante qual periodo o preço é: } & \multicolumn{12}{|c|}{ Volume de leite entregue ao mès } \\
\hline & & \multirow{2}{*}{$\begin{array}{c}\text { Fixo } \\
\text { por } \\
\text { ano }\end{array}$} & \multirow{2}{*}{$\begin{array}{c}\text { Variação } \\
\text { sazonal }\end{array}$} & \multirow{2}{*}{$\begin{array}{c}\text { Variaçăo } \\
\text { de merca- } \\
\text { do }\end{array}$} & \multicolumn{2}{|c|}{ O mais alto } & \multicolumn{2}{|c|}{ O mais baixo } & \multirow{2}{*}{$\begin{array}{c}\text { Jan } \\
\%\end{array}$} & \multirow{2}{*}{$\begin{array}{c}\mathrm{Fev} \\
\%\end{array}$} & \multirow{2}{*}{$\begin{array}{c}\text { Mar } \\
\%\end{array}$} & \multirow{2}{*}{$\begin{array}{c}A b r \\
\%\end{array}$} & \multirow{2}{*}{$\begin{array}{c}\text { Mai } \\
\%\end{array}$} & \multirow{2}{*}{$\begin{array}{c}\text { Jun } \\
\%\end{array}$} & \multirow{2}{*}{$\begin{array}{l}\text { Jul } \\
\%\end{array}$} & \multirow{2}{*}{$\begin{array}{r}\text { Ago } \\
\%\end{array}$} & \multirow{2}{*}{ Set } & \multirow{2}{*}{$\begin{array}{r}\text { Out } \\
\%\end{array}$} & \multirow{2}{*}{$\begin{array}{r}\text { Nov } \\
\%\end{array}$} & \multirow{2}{*}{$\begin{array}{r}\mathrm{Dez} \\
\%\end{array}$} \\
\hline & & & & & Inverno & Outono & Primav & Verầo & & & & & & & & & & & & \\
\hline Estados Unidos & 71375 & & & Sim & Sim & Sim & Sim & Sim & 8,38 & 8,03 & 8,65 & 8,43 & 8,86 & 8,67 & 8,65 & 8,31 & 7,82 & 8,04 & 7,83 & 8,33 \\
\hline India & 35600 & & Sim & & & & & & 9.00 & 9.00 & 9,00 & 8,00 & 7,00 & 7.00 & 7,00 & 7,00 & 8,00 & 9,00 & 10,00 & 10,00 \\
\hline Alemanha & 28500 & & Sim & Sim & & Sim & Sim & & 8,20 & 7,60 & 7,90 & 8,80 & 9,50 & 8,90 & 8,70 & 8,40 & 8,10 & 8,10 & 7,60 & 8,10 \\
\hline França & 24700 & & Sim & & Sim & Sim & Sim & & 8,39 & 7,81 & 7,06 & 9,87 & 10,47 & 9,31 & 8,29 & 7,20 & 6,70 & 7,42 & 7,48 & 8,00 \\
\hline Reino Unido & 14600 & & $\mathrm{Sim}$ & & & & Sim & & 8,40 & 7,70 & 8,30 & 9,10 & 10,80 & 8,40 & 8,10 & 7,50 & 7,60 & 7,80 & 7,70 & 8,50 \\
\hline Polônia & 12100 & & Sim & & $\operatorname{sim}$ & & & Sim & 7,00 & 6,00 & 7,00 & 7,00 & 8,00 & 10,00 & 12,00 & 12,00 & 10,00 & 8,00 & 7,00 & 6,00 \\
\hline Nova Zelândia & 11640 & Sim & & & & & & & 12,40 & 10,10 & 9,50 & 6,50 & 1,40 & 0,10 & 0,30 & 4,90 & 11,10 & 15,00 & 14,80 & 13,80 \\
\hline Holanda & 11200 & & Sim & Sim & Sim & & & Sim & 7,39 & 7,49 & 7.75 & 7,96 & 8.39 & 8,39 & 8.35 & 8,00 & 7,59 & 7.19 & 7.16 & 7,01 \\
\hline Austrália & 9656 & $\operatorname{sim}$ & & & & & & & & & & & & & & & & & & \\
\hline Japão & 8550 & $\operatorname{sim}$ & & & & & & & 8,20 & 7,80 & 8,50 & 8,40 & 8,80 & 8,60 & 8,70 & 8,40 & 8,10 & 8,30 & 7,90 & 9,30 \\
\hline Canada & 8200 & & & Sim & Sim & Sim & Sim & Sim & 8,40 & 7,90 & 8,50 & 8,40 & 8,80 & 8,50 & 8,40 & 8,60 & 8,20 & 8,20 & 7,90 & 8,20 \\
\hline Irlanda & 5681 & & Sim & & Sim & & & Sim & 4,00 & 6,00 & 8,00 & 12,00 & 13,00 & 12,00 & 11,00 & 10,00 & 9,00 & 7,00 & 5,00 & 3,00 \\
\hline Dinamarca & 4660 & & Sim & Sim & & Sim & Sim & & 8,17 & 7,33 & 8,33 & 8,75 & 9,33 & 9,00 & 8,83 & 8,50 & 8,00 & 8,08 & 7,67 & 8.08 \\
\hline Bélgica & 3460 & & Sim & & Sim & & & Sim & 7,00 & 7,00 & 8,50 & 9,50 & 10,00 & 10,00 & 9,50 & 8,50 & 8,00 & 7,50 & 7,50 & 7,00 \\
\hline Suécia & 3303 & & Sim & & & Sim & Sim & & 8,60 & 8,20 & 8,90 & 8,80 & 9,00 & 8,30 & 7,70 & 7,90 & 7,80 & 8,10 & 8,00 & 8,70 \\
\hline Austria & 3124 & Sim & & & & & & & & & & & & & & & & & & \\
\hline Finlândia & 2450 & & Sim & & & $\mathrm{Sim}$ & & Sim & 8,20 & 7,60 & 8,20 & 8,30 & 9,10 & 9,20 & 9,20 & 7,80 & 7,90 & 7,70 & 7,60 & 8,20 \\
\hline Tchecoslováquia & - & & $\mathrm{Sim}$ & & $\mathrm{Sim}$ & Sim & & $\mathrm{Sim}$ & 8,00 & 8,00 & 7,00 & 7,00 & 9,00 & 10,00 & 10,00 & 9,00 & 8,00 & 8,00 & 8,00 & 8,00 \\
\hline Israel & - & Sim & & & & & & & 8,66 & 8,16 & 9,36 & 9,14 & 9,27 & 8,49 & 8,30 & 7,63 & 7,19 & 7,70 & 7,68 & 8,42 \\
\hline Austrália (B) & & & Sim & Sim & Sim & Sim & Sim & Sim & 9,95 & 7,98 & 7,77 & 6,40 & 5,69 & 5,00 & 5,35 & 7,31 & 9,82 & 11,92 & 11,73 & 11,08 \\
\hline Quênia & - & & Sim & & & & Sim & & 8,98 & 7,58 & 8,97 & 8,91 & 9.17 & 8,33 & 7,68 & 7,77 & 7,85 & 8,34 & 8.07 & 8,38 \\
\hline Noruega & - & & Sim & & & & & & 9,30 & 8,20 & 9,20 & 8,80 & 8,70 & 8,00 & 7,20 & 7,00 & 7,70 & 8,40 & 8,70 & 8,60 \\
\hline Africa do Sul & 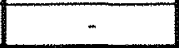 & $\operatorname{sim} 1$ & & Sim & Sim & & & Sim & 9,00 & 8,20 & 8,40 & 7,70 & 7,40 & 7,40 & 7,80 & 8,20 & 8,30 & 9,20 & 9,00 & 9,20 \\
\hline
\end{tabular}

Uma indústria tem quotas tipo $A, B, C$ e $D$ e o preço para $C$ e $D$ pode variar de acordo com o mercado local e com os preços de exportaçăo.

${ }^{2} \mathrm{Na}$ Tchecostováquia, além do invemo, o preço também é mais alto na primavera. E somente India e Noruega tém preços mais baixos no inverno.

Fonte: International Dairy Federation Bulletin, 1995, e elaboraçåo pela autora. 
Ainda que preço, volume, temperatura e qualidade sejam critérios comuns observáveis nos contratos, o nivel de importância de cada um deles varia de País para País, ou mesmo entre regiões, no caso de Países muito extensos.

A freqüência dos pagamentos também é diferente (quadro 8). Em 19 dos 22 Países levantados, as indústrias efetuam o pagamento aos produtores mensalmente e; em cinco deles o pagamento é feito quinzenalmente. Somente Israel o faz semanalmente. Na Índia o pagamento é feito após cada entrega ou a cada 10 dias. Incentivos aos produtores iniciantes, bom desempenho nos testes físico-químicos, raças específicas, rendimento industrial ou possibilidades de uso, preferência por raças, alimentação especifica, volume por entrega, criação intensiva ou extensiva, são alguns dos outros prêmios aplicáveis nos pagamentos por qualidade nos paises comentados.

Pelo quadro 11 que poucos Países praticam estas premiações, e a extensão destas aplicações varia de pais para país. Na Bélgica, por exemplo, não se utiliza nenhum dos prêmios citados anteriormente, mas sabe-se que indústrias, individualmente, premiam outros aspectos na produção de leite. $\mathrm{Na}$ Alemanha, a aplicação dos prêmios é regionalizada e eles incidem sobre a alimentação especifica.

$\mathrm{Na}$ França, a premiação pode ter escopo nacional, regional ou individualmente por cada uma das indústrias. Neste País, as premiações são as mais significativas e incidem sobre as análises laboratoriais do leite e raças especificas das vacas. Holanda e Nova Zelândia apenas premiam o bom desempenho nos testes físico-químicos.

No Brasil, os sistemas de pagamento por qualidade estão muito aquém destes relatados. Não existem formalizações contratuais e muito menos prêmios que privilegiem sistemas de produção, raças e alimentação especificas, ou bom desempenho nos testes físico-químicos. Entretanto, com a intensificação da granelização da coleta de leite frio nas regiões Sul, Sudeste e Centro-oeste, as exigências de qualidade na produção e no processamento do 
Quadro11: Detalhes acerca de prêmios diversos e o nivel de aplicação utilizados nos diferentes paises.

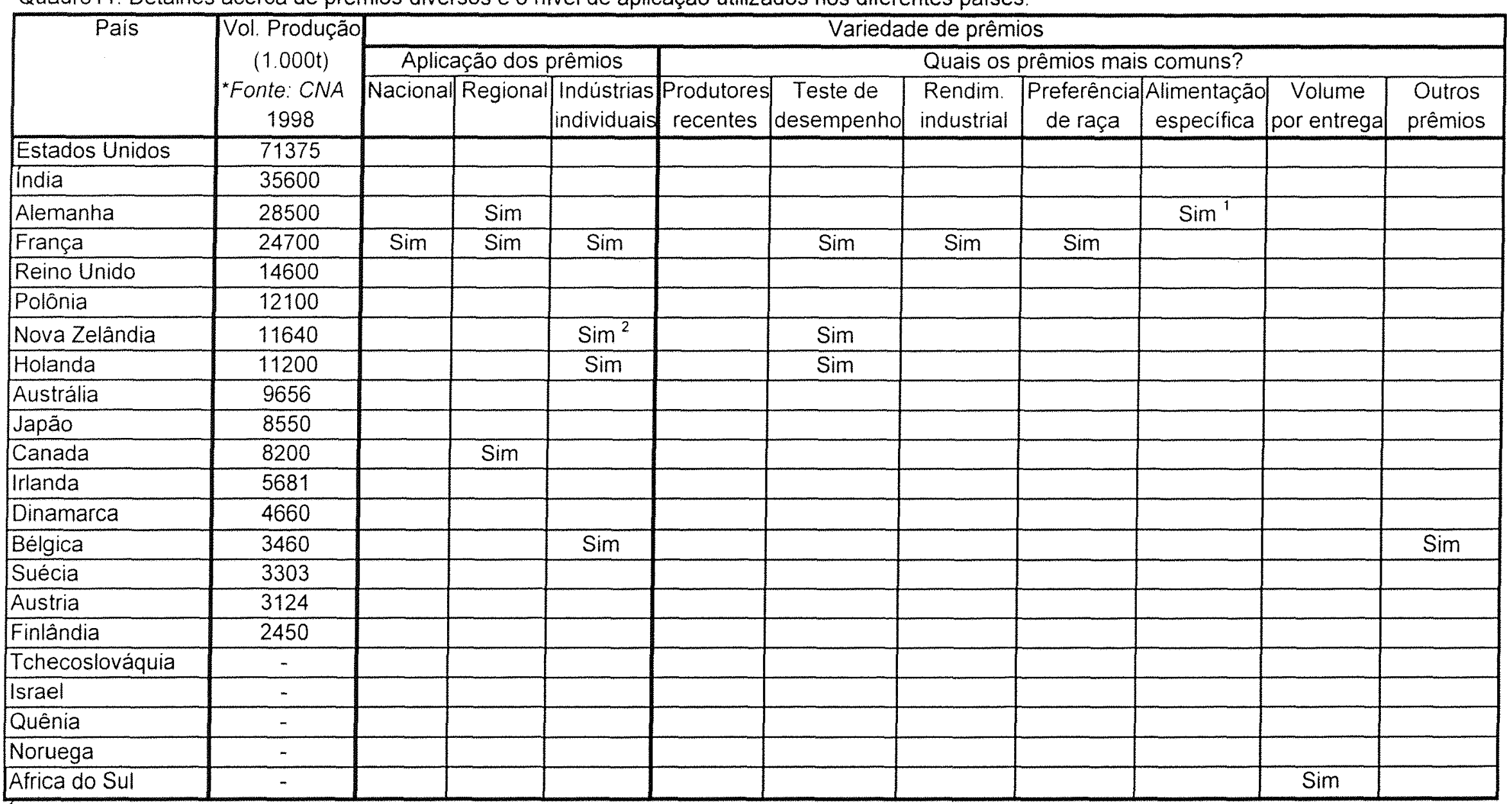

TPara queijo emental ou para leite fresco comercializado em garrafas de vidro não é permitido silagem na dieta das vacas.

2 Aplicado somente sobre o leite "out-of-season" (5\% dos produtores).

Fonte: International Dairy Federation Bulletin, 1995, elaboração pela autora. 
leite têm sido crescentes.

Contudo, a inexistência, ou a ineficiência, de um aparato oficial de fiscalização e controle da qualidade ao longo da cadeia produtiva de leite no Brasil, ainda permite que se observe indices baixíssimos de qualidade do produto e de seus derivados, quando comparado com Países desenvolvidos.

Durante os quarenta e seis anos (de 1945 a 1991) em que o leite teve seus preços controlados pelo governo, o setor leiteiro, como um todo, não se desenvolveu. Prova disso são as técnicas de produção da época colonial que ainda hoje são utilizadas. O controle da qualidade do produto, cuidados higiênicos e sanitários do gado, prêmios e outras formalizações no pagamento do leite ainda não estão definidos para o País.

Recentemente foi elaborada por uma comissão composta por representantes da iniciativa privada e entregue ao Ministro da Agricultura, em julho de 1999, uma proposta de Modernização do Setor Produtivo de Leite e Derivados. A proposta ${ }^{17}$ contempla três aspectos fundamentais para a modernização: a) a mudança das normas de produção, b) a capacitação da mão de obra e a disponibilização de recursos de infra-estrutura (estradas vicinais, eletrificação rural) e c) disponibilização de recursos financeiros com prazos e juros compativeis com a atividade.

Para a capacitação de mão de obra envolvida na produção e no transporte de leite cru o programa prevê o desembolso de $\mathrm{R} \$ 50$ milhões, dos quais $70 \%$ serão oriundos do setor público e $30 \%$ da iniciativa privada. A partir desta proposta, os produtores de leite poderão contar com financiamentos individuais de até $\mathrm{R} \$ 25$ mil do Banco Nacional de Desenvolvimento Econômico e Social (BNDES) para a compra de ordenhadeiras mecânicas, material de inseminação artificial, tanques de resfriamento, trituradores e outros itens

\footnotetext{
17 A proposta que se descreve a seguir é baseada numa sintese da Proposta Conciliatória elaborada pela Confederação Nacional da Agricultura e publicações via internet da própria CNA e do boletim do Leite (ESALQ), preparado pelo Técnico em Laticinios Antônio José Xavier AEX Consultoria e Serviços Ltda.
} 
diversos necessários à modernização do setor. Os limites estão estabelecidos na Resolução 2.618, aprovada pelo Conselho Monetário Nacional (CMN), que instituiu o Programa de Incentivo à Modernização, Resfriamento e Transporte Granelizado da Produção de Leite (PROLEITE) ${ }^{18}$.

Quanto às normas de produção, compreendem regulamentos para a produção de leite cru resfriado, para o transporte de leite a granel, para a produção de leite pasteurizado de qualidade superior à do leite tipo $\mathrm{C}$ e um decreto que modifica o Regulamento da Inspeção Industrial e Sanitária de Produtos de Origem Animal (RIISPOA) para ajustá-lo à nova realidade.

Tal proposta não extingue as denominações A, B e C até Julho de 2002 prazo em que todo o leite nacional deverá estar sendo coletado frio e a granel. ${ }^{19}$, mas cria condições para que no futuro os consumidores o façam, na medida em que cria um novo tipo de leite, de melhor qualidade que o de tipo $\mathrm{C}$, que hoje corresponde a mais de 95\% do leite produzido no Pais (Xavier, 1999). Este leite será denominado leite cru resfriado quando no estado de cru e apenas leite pasteurizado quando envasado após tratamento térmico. Para este leite será exigida a refrigeração na fazenda, a coleta a granel, serão fixados limites para as contagens de microorganismos e células somáticas. Os quadros 12 e 13 resumem alguns dos aspectos mais importantes do documento referentes a este aspecto.

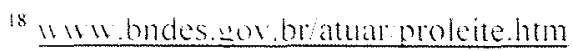

${ }_{10}$ Mirit cna-rumal.com br indice pecuáría de leite Última atualização 17/12/99.
} 
Quadro 12 - Requisitos microbiológicos, de CSS e de resíduos quimicos

\begin{tabular}{|c|c|c|c|}
\hline REQUISITOS E PERIDICIDADE & $\begin{array}{c}\text { A partir de: } \\
01 / 07 / 2002 \text { nas regiōes } \\
\text { Sul, Sudeste e Centro- } \\
\text { Oeste. } \\
\text { 01/07/2004 nas regiōes } \\
\text { Nordeste e Norte. }\end{array}$ & $\begin{array}{c}\text { A partir de: } \\
01 / 07 / 2005 \text { nas regiōes } \\
\text { Sul, Sudeste e Centro- } \\
\text { Oeste. } \\
\text { 01/07/2008 nas regiōes } \\
\text { Nordeste e Norte. }\end{array}$ & $\begin{array}{c}\text { A partir de : } \\
\text { 01/07/2008 nas regióes } \\
\text { Sul, Sudeste e Centro- } \\
\text { Oeste. } \\
\text { 01/07/20011 nas regiōes } \\
\text { Nordeste e Norte. }\end{array}$ \\
\hline $\begin{array}{c}\text { Contagem Padrăo em placas - ufc/ml } \\
\text { (média geométrica sobre um periodo de } 2 \\
\text { meses, com pelo menos } 2 \text { análises por més) }\end{array}$ & Máximo 1.000 .000 & Máximo 750.000 & $\begin{array}{c}\text { Produtores individuais } \\
\text { menor que } 100.000 \\
\text { Conjunto de produtores } \\
\text { menor que } 300.000 \\
\end{array}$ \\
\hline $\begin{array}{c}\text { Contagem de células somaticas/ml para } \\
\text { produtores individuais } \\
\text { (média geométrica sobre um periodo de } 4 \\
\text { meses, com pelo menos } 2 \text { análise por mès) }\end{array}$ & Máximo 1.000 .000 & Máximo 750.000 & Máximo 400.000 \\
\hline $\begin{array}{l}\text { Residuos de drogas (equivalentes em } \\
\text { antibióticos do grupo B-Lactam) } \\
\text { (pelo menos } 1 \text { análise por mès) }\end{array}$ & \multicolumn{3}{|c|}{ Menor que $0.05 \mathrm{UI} / \mathrm{ml}$} \\
\hline $\begin{array}{c}\text { Temperatura para o leite } 3 \text { horas após a } \\
\text { ordenha (cada ordenha) }\end{array}$ & \multicolumn{2}{|c|}{ Máximo $7^{\circ} \mathrm{C}$} & Máximo $4^{\circ} \mathrm{C}$ \\
\hline $\begin{array}{l}\text { Temperatura para recebimento na industria } \\
\text { (cada remessa) }\end{array}$ & \multicolumn{2}{|c|}{ Máximo $10^{\circ} \mathrm{C}$} & Máximo $7^{\circ} \mathrm{C}$ \\
\hline
\end{tabular}

Fonte: Xavier, A.J. Boletim do leite. 22/08/99

Quadro 13-Requisitos fisico-químicos

\begin{tabular}{|c|c|}
\hline REQUISITOS E PERIDICIDADE & LIMITES \\
\hline $\begin{array}{c}\text { Matéria }-G \text { orda } \mathrm{g} / 100 \mathrm{~g} \\
(2 \text { vezes ao mès })\end{array}$ & Minimo 3,0 (leite integral) \\
\hline $\begin{array}{c}\text { Densidade relativa à } 15 / 15^{\circ} \mathrm{C} \mathrm{g} / \mathrm{ml} \\
\text { (2 vezes ao més) }\end{array}$ & 1,028 a 1,034 \\
\hline $\begin{array}{c}\text { Acidez g ácido lático } / 100 \mathrm{ml} \\
(2 \text { vezes ao mês })\end{array}$ & 0,14 a 0,18 \\
\hline $\begin{array}{c}\text { Extrato seco desengordurado g/100 } \\
g(2 \text { vezes ao mês) }\end{array}$ & Minimo 8,4 \\
\hline $\begin{array}{l}\text { Indice Crioscópico } \\
(2 \text { vezes ao mês })\end{array}$ & $\begin{array}{c}\text { Máximo }-0,512^{\circ} \mathrm{C} \\
\text { (Equivalente a }-0,530^{\circ} \mathrm{H} \text { ) }\end{array}$ \\
\hline $\begin{array}{c}\text { Proteinas } \mathrm{g} / 100 \mathrm{~g} \\
\text { (a critério de comprador) }\end{array}$ & Minimo 2,9 \\
\hline
\end{tabular}

Fonte: Xavier, A.J. Boletim do leite. 22/08/99 
A modernização do setor dar-se-á em três etapas. Na primeira delas torna-se obrigatória a refrigeração do leite na propriedade produtora e o transporte a granel até a plataforma do laticínio. O produto deverá apresentar no máximo 1 milhão de unidades formadoras de colônias/ml e 1 milhão de células somáticas $/ \mathrm{ml}$. Esta etapa entrará em vigor em 01/07/2002 nas regiões Sul, Sudeste e Centro-Oeste e em 01/07/2004 nas regiões Norte e Nordeste.

Na segunda etapa, que entrará em vigor em 01/07/2005 no primeiro grupo de regiões e em 01/07/2008 no segundo, essa contagem deverá ser de no máximo $750 \mathrm{mil} / \mathrm{ml}$.

$\mathrm{Na}$ etapa final, que entrará em vigor a partir de 01/01/2008 no primeiro grupo de regiões e 01/01/2011 no segundo, são fixados limites máximos de 100 mil unidades formadoras de colônias $/ \mathrm{ml}$ e 400 mil células somáticas $/ \mathrm{ml}$ para leite de produtores individuais.

Nas duas primeiras etapas o leite deverá ser resfriado a uma temperatura inferior a $7^{\circ} \mathrm{C}$ em até 3 horas após a ordenha e chegar à plataforma da indústria à temperatura máxima de $10^{\circ} \mathrm{C}$. Na última etapa, essas temperaturas deverão ser de $4^{\circ} \mathrm{C}$ e $7^{\circ} \mathrm{C}$, respectivamente.

As empresas que provarem que já utilizam matéria-prima de acordo com as exigências contidas na primeira etapa poderão se antecipar e declarar isso nos rótulos de seus produtos.

Com esta proposta, pretende-se oferecer ao consumidor brasileiro, daqui a 10 anos, produtos lácteos fabricados apenas com matéria-prima de qualidade semelhante àquela que os paises de pecuária leiteira desenvolvida já utilizam atualmente. Tais paises se preocuparam, num primeiro momento, com a sanidade dos rebanhos e em eliminar os residuos e sedimentos eventualmente existentes no leite (areia, palha, esterco) e que carreavam uma parte importante das contaminações microbianas.

Ao eliminar os sedimentos, passaram então a se preocuparem com os microorganismos que foram inicialmente controlados através de métodos 
analíticos simples, rápidos e de baixo custo como o teste de redutase, que tem bom poder discriminante para classificar leites com elevadas contagens de bactérias.

Com a generalização do emprego do frio nas fazendas e a disponibilidade dos métodos eletrônicos de contagem de microorganismos, a redutase foi substituída pela contagem direta de bactérias, efetuada em laboratórios centralizados e dotados de equipamentos automatizados. Finalmente, quando o leite cru não mais apresentava sedimentos e a contagem de microorganismos estava suficientemente baixa, a ênfase voltou para a sanidade da glândula mamária do animal, através da contagem de células somáticas.

No Brasil, a granelização da coleta de leite propiciou um grande avanço no resfriamento do leite nas fazendas, movido principalmente pela necessidade de reduçäo de custos de captação. O controle da sanidade do rebanho, a eliminação da presença de sedimentos, a redução da carga microbiana e de células somáticas deverão ser desenvolvidos simultaneamente, muito embora não se deva deixar de lado a ordem das prioridades.

Segundo Xavier (1999), para que a qualidade da matéria-prima melhore o suficiente para ser equiparada àquela dos países desenvolvidos é necessário que haja excesso de oferta de leite em relação ao volume demandado para que seja possivel selecionar o leite recebido nas plataformas. Não é possível melhorar a qualidade do leite durante períodos de escassez. Quando falta matéria-prima, a indústria prefere receber um leite de qualidade inferior a deixar seu mercado desabastecido. Por sua vez, o consumidor prefere fazer concessões quanto à qualidade do leite ao invés de ficar sem consumi-lo. Assim, se o setor não conseguir produzir todo o leite que necessita (que hoje é suprida pelas importações), as metas ficarão comprometidas.

O programa também prevê a necessária presença de supervisores técnicos para orientar os produtores quanto às medidas de controle de drogas (antibióticos, carrapaticidas e vermífugos), indicando o descarte do leite após o 
uso desses produtos. Também se faz importante a indicação expressa nos rótulos de produtos farmacêuticos que deixam resíduos no leite.

Caberá ao Governo proporcionar ao setor produtivo as necessárias condições para a melhoria do seu desempenho na conquista de competitividade, que são:

- Disponibilidade de crédito, com taxas e prazos compatíveis com a atividade, para investimentos em máquinas, equipamentos $\mathrm{e}$ instalações;

- Adequada infra-estrutura de estradas, indispensável ao trânsito dos caminhões-tanque na coleta de leite à granel e energia elétrica nas propriedades rurais;

- Defesa contra importações desleais e predatórias, especialmente a abertura da investigação de prática de dumping de exportações de leite para o Brasil.

Em todos os niveis de implantação do programa será essencial o treinamento das pessoas envolvidas. Nas fazendas, o Serviço Nacional de Aprendizagem Rural (Senar) será um instrumento fundamental para profissionalização da pecuária do leite, com vistas a atingir o padrão imposto pelos mercados interno e externo.

O programa conta com a iniciativa conjunta da Associação Brasileira dos Produtores de Leite (Leite Brasil), Confederação Brasileira das Cooperativas de Laticinios, Organização das Cooperativas Brasileiras (OCB), Conselho Nacional das Indústrias de Laticínios (Conil), Associação Brasileira de Leite Longa Vida (ABVL), Associação Brasileira das Indústrias de Queijo (ABIQ), Associação Brasileira das Indústrias da Alimentação (ABIA) e Sociedade Rural Brasileira (SRB), sob a coordenação da Confederação Nacional da Agricultura (CNA).

No longo prazo, o Programa também prevê que se estabeleça uma norma comum para a coleta a granel, como aquela que já é praticada no Estado de 
São Paulo desde $1997^{20}$

Pelo que se observa, o grande desafio do setor leiteiro como um todo passa a ser a integração da ação do governo e das empresas privadas e de cooperativas que atuam no setor. A qualidade do leite brasileiro reflete as condições conjunturais do País. Assim, as mudanças no setor só serão efetivas à medida que se mude o paradigma de eficiência produtiva e de qualidade para o consumidor. A ação coordenada e conjunta dos agentes do setor passa a ser, dessa forma, o determinante de mudanças estruturais necessárias para o avanço progressivo na modernização da pecuária leiteira nacional.

${ }^{20} \mathrm{Ver}$ anexo D. 


\section{A COLETA A GRANEL E AS RELAÇÕES PRODUTOR/INDÚSTRIA}

Este capitulo trata do objetivo principal do estudo. Baseado num estudo de caso, a finalidade deste capítulo é retratar as implicações que a modernização do sistema de captação de leite teve sobre as relações contratuais entre os produtores e uma determinada empresa de laticínios na região Sudoeste de Minas Gerais.

Na primeira seção, apresenta-se a avaliação quantitativa da granelização da coleta de leite na região estudada. Seguindo os procedimentos metodológicos propostos no capitulo três, as avaliaçōes das entrevistas são apresentadas na segunda seção, onde também são discutidas as formas de governança vigente e a esperada.

\subsection{Avaliação quantitativa da granelização da coleta de leite}

A implantação da coleta a granel de leite refrigerado na região Sudoeste de Minas Gerais iniciou-se em 1996 e tem previsão para conclusão no ano 2000 , com $100 \%$ da coleta de leite sendo feita a frio e a granel. Seu avanço tem sido observado na progressiva redução de custos operacionais na fábrica em termos do número de rotas racionalizadas, volume de leite transportado por quilômetro percorrido e melhoria da qualidade do leite coletado. 
A principal atividade desenvolvida na região é a pecuária leiteira $(42,8 \%$ dos entrevistados), sendo também cultivados milho $(28 \%)$, arroz ( $3 \%)$, feijão $(3 \%)$, café $(9 \%)$, recria de bezerros para venda $(9 \%)$. Cerca de metade dos entrevistados desenvolvem a pecuária leiteira e outra atividade paralela, principalmente o milho.

A criação do gado é tipicamente extensiva ( $90 \%$ dos entrevistados) com suplementação de pasto no período da seca, sendo o bagaço de cana-deaçúcar o principal suplemento utilizado. Poucas propriedades adotam ordenhadeiras mecânicas - apenas $20 \%$ delas, e as instalações, em geral, são precárias. Entretanto, com a granelização da coleta de leite frio tem havido uma melhoria progressiva nas instalações e em pavimentações das estradas rurais.

A captação de leite feita na região, na ocasião da pesquisa de campo em 1998, situava-se em torno de 610.626 litros de leite por dia (I/d), sendo, $27 \%$, ou, 164.869 I deste leite coletado a granel. Os números do processo podem ser melhor visualizados e comparados a seguir.

Pela tabela 1 pode-se perceber que houve uma significativa redução do número de rotas (que passou de 239 para 128 no total) e da quantidade de quilômetros percorridos (de 26.589 para 12.149 ao dia), que praticamente foram de $50 \%$. Por sua vez, o volume de leite coletado por quilômetro percorrido duplicou, passando de 27,72 para $59,94 \mathrm{l} / \mathrm{d}$. 
Tabela 1: Análise comparativa de alguns índices de desempenho antes e após a granelização da coleta de leite na região estudada

\begin{tabular}{|c|c|c|c|c|c|c|c|c|c|}
\hline & \multicolumn{4}{|c|}{ ANTES } & \multicolumn{5}{|c|}{ APOS } \\
\hline $\mathrm{DL}^{21}$ & $\begin{array}{l}\text { ROTAS } \\
(\mathrm{N} \text { O })\end{array}$ & $\begin{array}{l}\text { KM 10 } \\
\text { PERC/ } \\
\text { DIA }\end{array}$ & $\begin{array}{l}\text { LEITE } \\
\text { L/DIA }\end{array}$ & $\begin{array}{l}\text { L/ KM } \\
\text { ROD. }\end{array}$ & $\begin{array}{c}\text { ROTAS } \\
\text { (№) }\end{array}$ & $\begin{array}{c}1 \underline{0} \\
\text { PERC/ } \\
\text { DIA }\end{array}$ & $\begin{array}{l}\text { LEITE } \\
\text { L/DIA }\end{array}$ & $\begin{array}{l}\text { L/KM } \\
\text { ROD. }\end{array}$ & $\begin{array}{l}\text { N-TAN- } \\
\text { QUES DE } \\
\text { COLETA }\end{array}$ \\
\hline 1 & 10 & 1.131 & 29.300 & 26,90 & 7 & 419 & 25.450 & 60,74 & 2 \\
\hline 2 & 22 & 2.572 & 67.901 & 26,40 & 17 & 1.008 & 67.565 & 67,06 & 5 \\
\hline 3 & 7 & 657 & 37.400 & 56,95 & 6 & 369 & 37.400 & 101,36 & 3 \\
\hline 4 & 9 & 725 & 18.440 & 25,43 & 4 & 343 & 17.475 & 51,02 & 2 \\
\hline 5 & 15 & 1.292 & 34.200 & 26,47 & 7 & 639 & 31.550 & 49,35 & 3 \\
\hline 6 & 6 & 751 & 17.805 & 23,71 & 2 & 400 & 16.515 & 41,28 & 1 \\
\hline 7 & 10 & 820 & 26.700 & 32,56 & 7 & 311 & 26.380 & 84,78 & 2 \\
\hline 8 & 7 & 668 & 21.420 & 32,07 & 5 & 283 & 19.000 & 67,26 & 2 \\
\hline 9 & 7 & 477 & 18.790 & 39,39 & 5 & 188 & 17.510 & 92,92 & 1 \\
\hline 10 & 22 & 1.830 & 54.520 & 29,79 & 5 & 576 & 54.600 & 94,87 & 5 \\
\hline 11 & 20 & 2.743 & 34.832 & 12,70 & 6 & 1.626 & 32.571 & 20,03 & 4 \\
\hline 12 & 12 & 1.411 & 31.900 & 22,61 & 6 & 549 & 31.200 & 56,88 & 3 \\
\hline 13 & 14 & 2.107 & 30.850 & 14,64 & 8 & 847 & 29.000 & 34,24 & 3 \\
\hline 14 & 19 & 2.710 & 61.960 & 22,86 & 10 & 875 & 46.660 & 53,33 & 4 \\
\hline 15 & 11 & 864 & 23.230 & 26,88 & 4 & 348 & 22.500 & 64,65 & 2 \\
\hline 16 & 8 & 640 & 28.120 & 43,94 & 8 & 334 & 27.850 & 83,42 & 2 \\
\hline 17 & 11 & 1.324 & 24.000 & 18,13 & 5 & 565 & 24.000 & 42,52 & 3 \\
\hline 18 & 16 & 1.905 & 59.100 & 31,02 & 9 & 1.140 & 46.400 & 40,72 & 5 \\
\hline 19 & 13 & 1.962 & 21.052 & 10,72 & 5 & 939 & 21.700 & 23,12 & 3 \\
\hline 20 & - & & - & - & 2 & 393 & 15.300 & 38,93 & 1 \\
\hline $\mathrm{FAB}^{\star}$ & 239 & 26.589 & 641.493 & 27,72 & 128 & 12.149 & 610.626 & 59,94 & 56 \\
\hline
\end{tabular}

*FAB = fábrica

Fonte: Dados coletados na pesquisa.

A tabela também mostra que houve uma pequena redução no volume total de leite coletado, de 641.493 para $610.626 \mathrm{l} / \mathrm{d}$. Isto se deveu ao fato de que, com a granelização e o mapeamento de rotas, alguns produtores foram excluídos, seja porque não quiseram aderir ao processo, seja porque sua propriedade situava-se em local de difícil acesso para o caminhão-tanque.

Pela tabela 2 , pode-se perceber que há uma predominância em demanda por resfriadores de menor capacidade. A última linha da tabela nos diz qual o percentual de resfriadores necessários para a região segundo as respectivas capacidades. Através deste mesmo quadro observa-se que a capacidade

${ }^{21}$ A abreviatura "DL" que aparece nas tabelas desta seção significam "distrito leiteiro" e os 
média de tanques utilizados na região é de 683,16 litros. Embora a média encontrada seja alta, ela está sendo afetada pelo uso dos poucos resfriadores com grande capacidade na região. Observando ainda a tabela 2 , vê-se que 1.939 dos 2.808 resfriadores necessários têm capacidade menor que a média observada e que $36,25 \%$ do total de produtores utilizam tanques de $300 \mathrm{I}$. Apenas $0,006 \%$ deles possuem resfriadores com capacidade de 3000 I. As necessidades de resfriadores de expansão são apresentadas no tabela 2 e ilustradas na figura 2 .

Observa-se pelos números da tabela, e confirma-se pela figura 3 , posteriormente, que a relação dos preços dos resfriadores por suas respectivas capacidades esboça uma economia de escala para o produtor à medida que ele conseguir ampliar seu volume de produção diário de leite e com isso utilizar um resfriador de maior capacidade.

A importância de se retratar esta relação está em se considerar que os investimentos feitos pela indústria são pagos pelo produtor em litros de leite. Ao perceber que o custo do resfriador por litro de leite diminui com o aumento da sua capacidade, os produtores se sentem estimulados a aumentar seu volume de produção e, consequentemente, a beneficiar-se de economias de escala. 
Tabela 2: Necessidade de resfriadores de expansão por distrito leiteiro e respectivas capacidades

\begin{tabular}{ccccccccccccc}
\hline $\mathrm{DL}$ & $300 \mathrm{~L}$ & $360 \mathrm{~L}$ & $520 \mathrm{~L}$ & $670 \mathrm{~L}$ & $750 \mathrm{~L}$ & $825 \mathrm{~L}$ & $1000 \mathrm{~L}$ & $1500 \mathrm{~L}$ & $2000 \mathrm{~L}$ & $2500 \mathrm{~L}$ & $3000 \mathrm{~L}$ TOTAL \\
\hline 1 & - & 14 & 16 & 10 & - & 9 & 17 & 6 & 3 & 4 & 4 & 83 \\
2 & 13 & 51 & 11 & 25 & - & 21 & 26 & 37 & 17 & 14 & 4 & 219 \\
3 & 31 & 19 & 28 & 7 & 18 & 6 & 11 & 15 & 2 & 3 & 3 & 143 \\
4 & 23 & 28 & 9 & - & 12 & - & 21 & 13 & - & - & - & 106 \\
5 & 76 & 16 & 44 & 7 & 14 & - & 17 & 6 & 1 & 2 & 1 & 184 \\
6 & 41 & 4 & 20 & 16 & - & 2 & 2 & 2 & 2 & - & - & 89 \\
7 & 42 & - & 37 & - & 18 & 7 & 6 & 10 & - & - & - & 120 \\
8 & 4 & 7 & 2 & 4 & 8 & - & 3 & 9 & 4 & 3 & 2 & 46 \\
9 & 18 & 2 & 10 & - & 11 & 15 & 6 & 4 & 1 & - & - & 67 \\
10 & 162 & - & 85 & - & - & - & 34 & - & 18 & 14 & - & 313 \\
11 & 40 & 63 & - & 59 & - & - & 22 & - & 9 & - & - & 193 \\
12 & 51 & - & 31 & - & - & - & 25 & - & 9 & - & - & 116 \\
13 & 115 & - & 57 & - & - & - & 27 & - & 11 & - & - & 210 \\
14 & 101 & - & 50 & - & 29 & - & 25 & 13 & 13 & 2 & - & 233 \\
15 & 41 & - & 25 & 11 & - & 6 & 4 & 15 & - & - & 1 & 103 \\
16 & 52 & 6 & 12 & 12 & - & 14 & 13 & 6 & 8 & 6 & 2 & 131 \\
17 & 61 & - & 18 & - & 5 & 4 & 2 & 1 & - & - & - & 91 \\
18 & 46 & 26 & 38 & - & 20 & - & 16 & - & 7 & 5 & - & 158 \\
19 & 73 & - & 29 & - & - & - & 21 & 8 & 3 & 3 & - & 137 \\
20 & 28 & - & 12 & - & 6 & - & 4 & 10 & 4 & 2 & - & 66 \\
\hline FAB & 1018 & 236 & 534 & 151 & 141 & 58 & 314 & 154 & 126 & 59 & 17 & 2808 \\
\hline$\%$ & 36.25 & 8.4 & 19.01 & 5.37 & 5.02 & 2.06 & 11.18 & 5.48 & 4.49 & 2.1 & 0.61 & 100 \\
\hline
\end{tabular}

Fonte: Dados coletados na pesquisa.

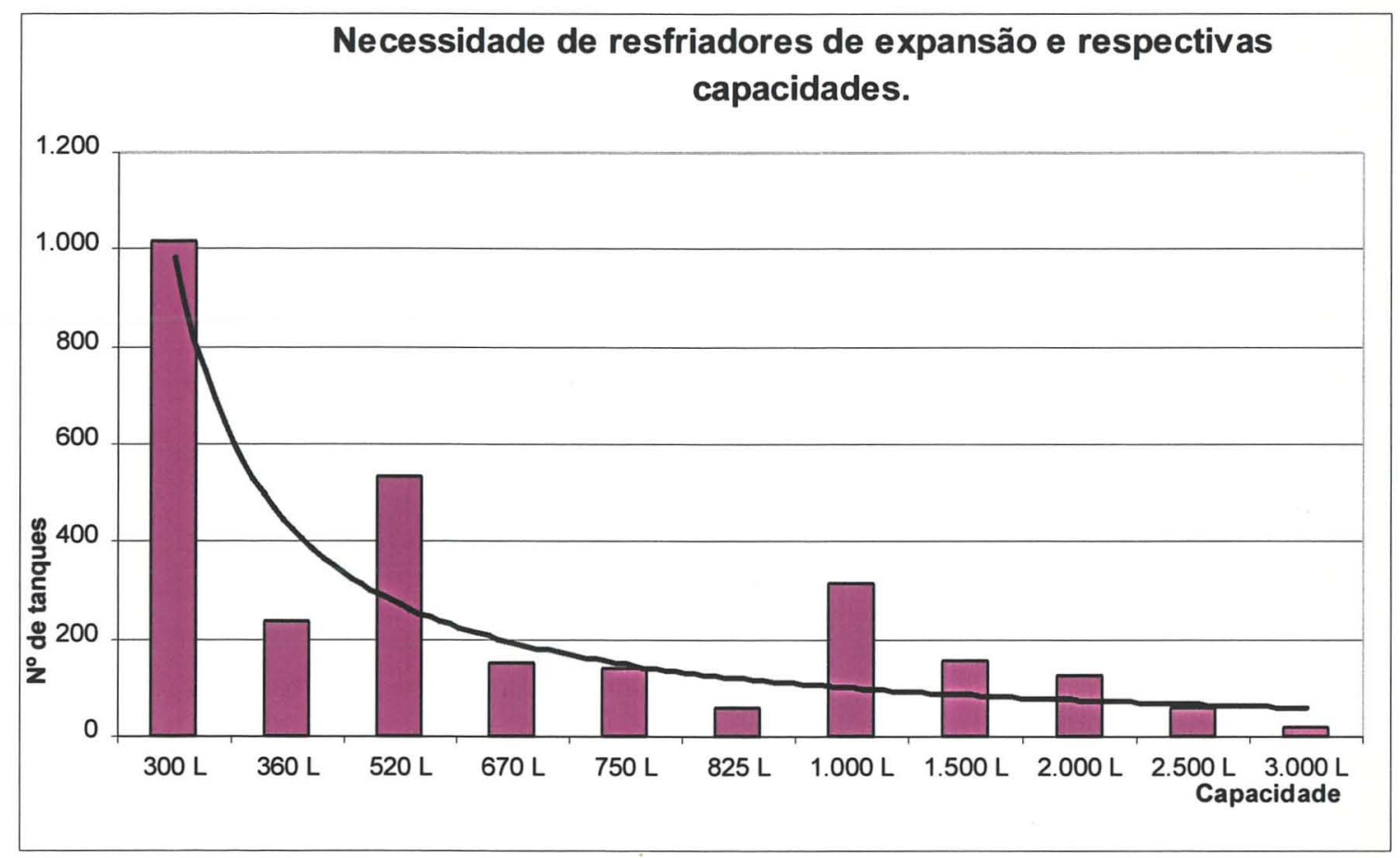

Figura 2: Relações de uso e capacidade dos resfriadores de leite 
Tabela 3 -:Relação de custos por capacidade do resfriador de leite

\begin{tabular}{cc}
\hline Capacidade do tanque (I) & Custo por litro (R\$I) \\
\hline \hline 220 & 13,41 \\
500 & 7,53 \\
520 & 7,22 \\
600 & 6,19 \\
730 & 6,27 \\
800 & 5,69 \\
1000 & 5,28 \\
1030 & 5,27 \\
1500 & 4,02 \\
1600 & 4,40 \\
2000 & 5,70 \\
2500 & 4,62 \\
3000 & 4,09 \\
4000 & 4,33 \\
4500 & 4,27 \\
5000 & 5,24 \\
6000 & 4,13 \\
7000 & 4,09 \\
10000 & 4,39 \\
\hline
\end{tabular}

Fonte: Projeto IPEA/PENSA/USP, 1998.

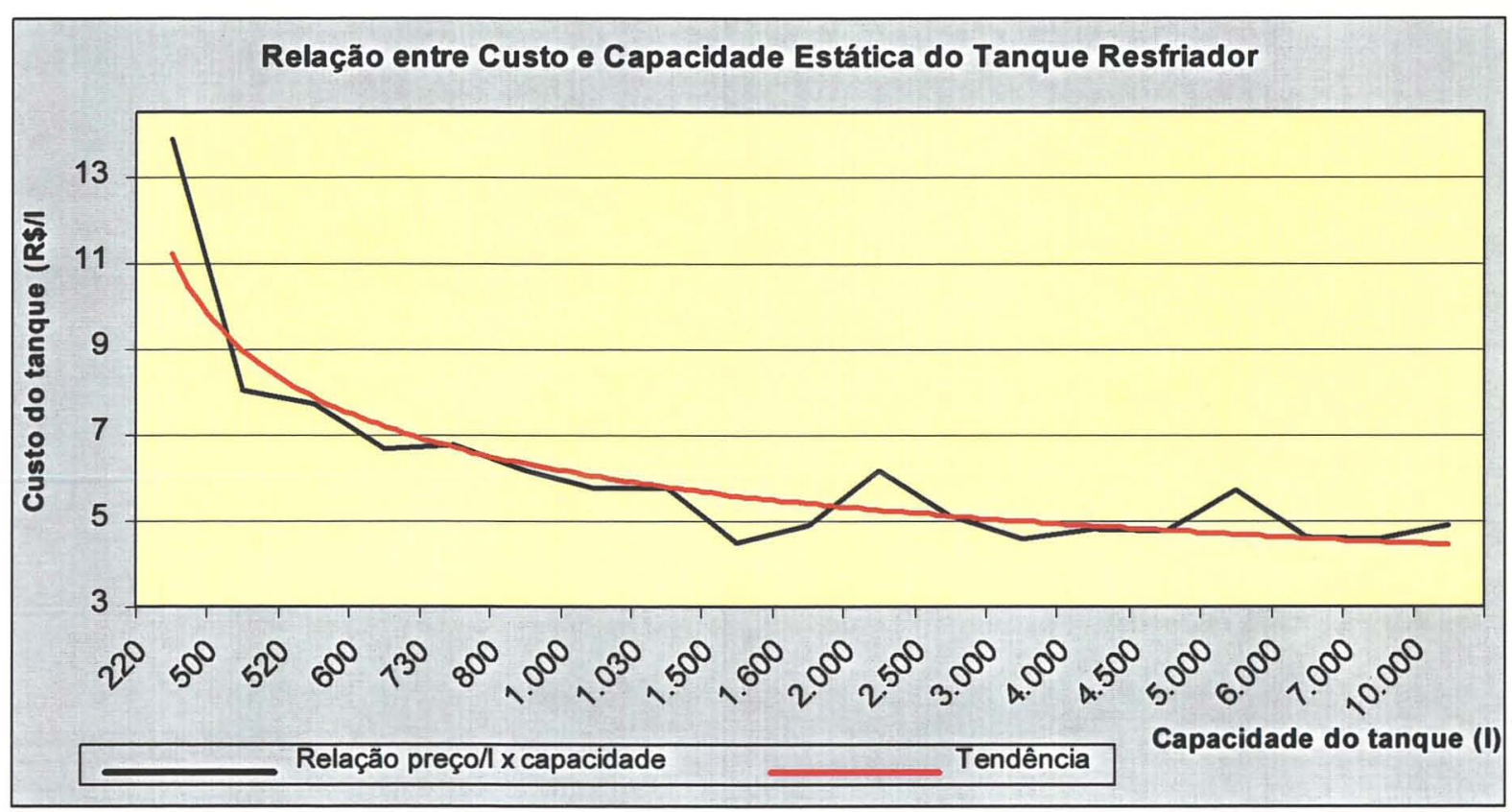

Figura 3: Economias de escala no resfriamento de leite 
A tabela 4, a seguir, relaciona o número necessário de resfriadores de expansão ao seu valor, ao custo de construção do abrigo, aos custos de aquisição de tanques rodoviários e ao valor do investimento necessário em cada um dos municípios que compõem o distrito leiteiro de lbiá para a implantação do projeto de coleta a granel.

Relacionando os números dos custos totais representados neste quadro às respectivas necessidades da fábrica, mostradas na sua última linha, obtémse que o custo médio de investimento em tanques por propriedade é de R $\$$ $4.924,10$ e o custo médio por tanque rodoviário é de $R \$ 23.000,00$.

Tomando-se o total de investimentos, apresentado na tabela 4 , e dividindo-se pela captação total de leite na fábrica (610.6261), tem-se que o custo médio de investimento em termos do volume de leite coletado é de R\$ $24,75 /$.

Tabela 4: Estimativas de custos do projeto de granelização do leite na região

\begin{tabular}{|c|c|c|c|c|c|c|c|}
\hline \multicolumn{3}{|c|}{$\begin{array}{l}\text { RESFR. DE } \\
\text { EXPANSÃO }\end{array}$} & \multicolumn{2}{|c|}{$\begin{array}{c}\text { ABRIGO PI } \\
\text { RESFRIADOR }\end{array}$} & \multicolumn{2}{|c|}{$\begin{array}{l}\text { TANQUES } \\
\text { RODOVIARIOS }\end{array}$} & \multirow{2}{*}{$\begin{array}{l}\text { TOTAL } \\
\text { VALOR } \\
\text { INVEST. }\end{array}$} \\
\hline$\overline{\mathrm{DL}}$ & QUANT & VALOR(R\$) & QUANT & VALOR(R\$) & QUANT & VALOR(R\$) & \\
\hline 1 & 83 & 388.871 & 83 & 83.000 & 2 & 46.000 & 517.871 \\
\hline 2 & 219 & 1.059 .431 & 219 & 219.000 & 5 & 115.000 & 1.393 .438 \\
\hline 3 & 143 & 592.680 & 143 & 143.000 & 3 & 69.000 & 804.680 \\
\hline 4 & 106 & 441.867 & 106 & 106.000 & 2 & 46.000 & 563.867 \\
\hline 5 & 184 & 660.489 & 184 & 184.000 & 3 & 69.000 & 913.489 \\
\hline 6 & 89 & 294.868 & 89 & 89.000 & 1 & 23.000 & 406.868 \\
\hline 7 & 120 & 471.453 & 120 & 120.000 & 2 & 46.000 & 637.453 \\
\hline 8 & 46 & 233.804 & 46 & 46.000 & 1 & 23.000 & 302.804 \\
\hline 9 & 67 & 301.209 & 67 & 67.000 & 2 & 46.000 & 414.209 \\
\hline 10 & 313 & 1.156 .290 & 313 & 313.000 & 5 & 115.000 & 1.584 .290 \\
\hline 11 & 193 & 693.237 & 193 & 193.000 & 4 & 92.000 & 978.237 \\
\hline 12 & 116 & 450.689 & 116 & 116.000 & 3 & 69.000 & 635.689 \\
\hline 13 & 210 & 739.863 & 210 & 210.000 & 3 & 69.000 & 1.018 .863 \\
\hline 14 & 233 & 914.695 & 233 & 233.000 & 4 & 92.000 & 1.239 .695 \\
\hline 15 & 103 & 393.950 & 103 & 103.000 & 2 & 46.000 & 542.950 \\
\hline 16 & 131 & 534.411 & 131 & 131.000 & 2 & 46.000 & 711.411 \\
\hline 17 & 91 & 294.922 & 91 & 91.000 & 3 & 69.000 & 454.922 \\
\hline 18 & 158 & 599.684 & 158 & 158.000 & 5 & 115.000 & 872.684 \\
\hline 19 & 137 & 517.451 & 137 & 137.000 & 3 & 69.000 & 723.451 \\
\hline 20 & 66 & 279.028 & 66 & 66.000 & 1 & 23.000 & 368.028 \\
\hline FAB & 2.808 & 11.018 .892 & 2.808 & 2.808 .000 & 56 & 1.288 .000 & 15.114 .892 \\
\hline
\end{tabular}

Fonte: Dados coletados na pesquisa. 
$\mathrm{Na}$ fase inicial da implantação do projeto são necessários também alguns investimentos em infra-estrutura para o suporte da operacionalização do novo sistema de coleta de leite. A tabela 5 mostra os recursos necessários.

Tabela 5: Infra-estrutura mínima necessária à viabilização do projeto de granelização do leite na região

\begin{tabular}{|c|c|c|c|c|c|c|c|c|c|}
\hline \multirow{2}{*}{$\mathrm{DL}$} & \multicolumn{2}{|c|}{$\begin{array}{c}\text { ELETRIFICAÇÃO } \\
\text { RURAL }\end{array}$} & \multicolumn{2}{|c|}{$\begin{array}{c}\text { REC. DE } \\
\text { ESTRADAS }\end{array}$} & \multicolumn{2}{|c|}{$\begin{array}{l}\text { REC. MATA } \\
\text { BURROS }\end{array}$} & \multicolumn{2}{|c|}{$\begin{array}{l}\text { REC. DE } \\
\text { PONTES }\end{array}$} & \multirow{2}{*}{$\begin{array}{c}\text { VALOR } \\
\text { TOTAL } \\
\text { RS }\end{array}$} \\
\hline & $\mathrm{N}^{\circ}$ & VALOR (R\$) & $\mathrm{KM}$ & $\begin{array}{l}\text { VALOR } \\
\text { (R\$) }\end{array}$ & $\mathrm{N}^{\circ}$ & $\begin{array}{l}\text { VALOR } \\
\text { (R\$) }\end{array}$ & $N^{\circ}$ & $\begin{array}{l}\text { VALOR } \\
\text { (R\$) }\end{array}$ & \\
\hline 1 & 4 & 40.000 & 42 & 33.600 & 18 & 5.400 & 5 & 6.000 & 85.000 \\
\hline 2 & 10 & 100.000 & 82 & 65.600 & 32 & 9.600 & 8 & 40.000 & 215.200 \\
\hline 3 & 12 & 72.000 & 32 & 25.600 & 16 & 4.800 & 3 & 3.000 & 105.400 \\
\hline 4 & 15 & 135.000 & 34 & 27.200 & 12 & 3.600 & 2 & 15.000 & 180.800 \\
\hline 5 & 8 & 5.000 & 65 & 52.000 & 15 & 4.500 & 4 & 6.000 & 1.124 .500 \\
\hline 6 & 8 & 48.000 & 40 & 32.000 & 18 & 5.400 & 6 & 6.000 & 91.400 \\
\hline 7 & 3 & 30.000 & 46 & 36.800 & 5 & 1.500 & - & . & 81.800 \\
\hline 8 & - & - & 22 & 17.600 & 4 & 1.200 & 1 & 2.000 & 20.800 \\
\hline 9 & 10 & 65.000 & 38 & 30.400 & 14 & 4.200 & 6 & 9.000 & 108.600 \\
\hline 10 & - & - & 57 & 45.600 & 32 & 9.600 & 9 & 18.000 & 73.200 \\
\hline 11 & 36 & 280.000 & 120 & 96.000 & 35 & 10.500 & 24 & 48.000 & 434.500 \\
\hline 12 & 26 & 260.000 & 54 & 43.200 & 19 & 5.700 & 7 & 35.000 & 343.900 \\
\hline 13 & 38 & 155.000 & 80 & 64.000 & 18 & 5.400 & 5 & 5.000 & 229.400 \\
\hline 14 & 14 & 168.000 & 87 & 69.600 & 41 & 12.300 & 3 & 5.000 & 254.900 \\
\hline 15 & - & . & 30 & 24.000 & 12 & 3.600 & 4 & 4.000 & 31.600 \\
\hline 16 & - & - & 35 & 28.000 & 17 & 5.100 & 8 & 20.000 & 53.100 \\
\hline 17 & - & . & 62 & 49.600 & 19 & 57.000 & 4 & 20.000 & 75.300 \\
\hline 18 & 3 & 12.000 & 110 & 88.000 & 45 & 13.500 & - & - & 113.500 \\
\hline 19 & 21 & 98.000 & 90 & 72.000 & 41 & 12.300 & 2 & 5.000 & 187.300 \\
\hline 20 & 5 & 60.000 & 27 & 21.600 & 15 & 4.500 & 2 & 3.000 & 89.100 \\
\hline FAB & 205 & 1.573 .000 & 1.153 & 922.400 & 428 & 128.400 & 103 & 250.000 & 2.873 .800 \\
\hline
\end{tabular}

Fonte: Dados coletados na pesquisa.

$\mathrm{Na}$ associação feita anteriormente sobre os custos totais de investimento não foram considerados aqueles em infra-estrutura, porque eles não foram necessários em todas as propriedades, mas sim em apenas 205 delas, ou em $7,3 \%$ do total. Estas propriedades são principalmente aquelas desprovidas de energia elétrica e que são passiveis de serem eletrificadas a curto e médio prazos para integrarem o projeto de granelização do leite na região.

A apresentação de tais dados justifica-se nas considerações feitas no início do estudo sobre os altos custos de investimentos que envolvem o 
processo de granelização da coleta de leite na sua fase inicial. Com o desenvolvimento do processo não serão mais necessários investimentos significativos e freqüentes em eletrificação rural, recuperação de estradas, de mata burros e de pontes. Além disso, o custo de captação do leite pela fábrica deverá se reduzir ainda mais (expectativa de $50 \%$ de redução) devido à economia de energia elétrica, já que o leite chegará frio à plataforma industrial.

\subsection{Avaliação qualitativa da granelização da coleta de leite}

A ida ao campo permitiu, além de uma convivência com a realidade do produtor de leite e da fábrica de derivados, analisar a hipótese levantada acerca dos beneficios mútuos para os agentes envolvidos e eficiência produtiva que a coleta a granel está trazendo ao setor leiteiro neste pais.

Ambas as partes, produtor e indústria, advogam que a coleta a granel propiciou a humanização do trabalho de ordenha, a quase eliminação das perdas com leite ácido, a possibilidade de se educar o produtor e de modernizar a atividade leiteira, e estimulou cuidados com a higiene na produção e no transporte do leite.

Entre as principais dificuldades que o processo revelou na região, tanto para os produtores quanto para a indústria, figuram a má conservação das estradas; os altos custos iniciais de investimento em tanques e abrigos nas propriedades - muito embora estes sejam financiados pela indústria num prazo de 36 a 48 meses sem juros; e os defeitos nos tanques e sua ociosidade inicial, quando a produção ainda não está regular, o que acarreta acréscimos no consumo de energia elétrica. 


\subsubsection{Sobre as relações entre produtor e indústria de leite}

A mudança no sistema de coleta de leite contribuiu para a aproximação entre os produtores e a indústria laticinista no caso em estudo. Porém, a granelização da coleta de leite não estimulou a formação de uma nova governança nas interações contratuais entre estes agentes, cujos principais vínculos passaram a ser a cumplicidade, a confiança e a fidelidade.

Tais comportamentos puderam ser percebidos através da aplicação do questionário e das entrevistas realizadas pessoalmente. A forma como as perguntas foram elaboradas permitiu avaliar o quão empenhados no processo os agentes estão, e decorrente disso, como eles se relacionam entre si e com o próprio negócio.

A fim de ilustrar o posicionamento de ambas as partes - indústria e produtor de leite - na transação de compra e venda do produto, apresenta-se, nesta seção, uma narrativa descritiva do comportamento dos respectivos agentes. Estas narrativas ilustram situações bilaterais dos agentes na transação e como eles formam suas expectativas sobre a conduta contratual do parceiro, conforme sejam comprador ou fornecedor de leite. Da mesma forma, são comentados os atributos da transação e sua respectiva implicação sobre a estrutura de governança associada antes e depois da coleta a granel de leite refrigerado, conforme proposto na seção 3.2.Procedimentos Metodológicos.

Observando-se as avaliações sobre a natureza da transação, antes e depois da coleta a granel, observa-se que houve um aumento de vínculos, risco e especificidades gerados com a intensificação do processo na região.

Como a coleta passou a ser feita em dias alternados, foi preciso conscientizar os produtores da necessidade de refrigeração do leite e dos cuidados de higiene na ordenha para que ele não perdesse seu produto. A conscientização do produtores permitiu que as partes estreitassem suas relações no sentido de estabelecer critérios para a comercialização da matéria- 
prima: o produtor resfria o leite e a indústria the paga um adicional por isto, como forma de incentivá-lo. A título de ilustração, esta é uma conduta adotada em alguns Países que não adotam contratos entre produtor $e$ indústria de leite, como Estados Unidos e Israel, mas pagam um adicional pela qualidade do leite.

A incerteza, ou risco do negócio, aumentou na medida em que foi exigida do produtor uma especialização, ainda que mínima. Com os investimentos dedicados em resfriadores de expansão e em construção de abrigos, a atividade de "produtor de leite" assumiu uma certa especificidade para aqueles produtores que antes eram simples "tiradores" de leite.

Os dias alternados na coleta a granel de leite e as exigências de qualidade na sua conservação e no manejo do rebanho fizeram com que os produtores aprendessem a regularizar seu volume de produção. Ao incorporar a produção de duas ordenhas diárias numa mesma coleta, os produtores ganharam em escala e, com isso, conseguiram maximizar sua receita mensal. Através do planejamento da produção, os produtores deixaram de se comportar como safristas e, em contrapartida, passaram a suportar menos grandes oscilações no preço do leite. A expectativa sobre o diferencial entre os preços mínimo e máximo foi reduzido. Nesse sentido, observa-se que o risco associado ao negócio está relacionado com a especialização da atividade produtiva e, quanto maior esta especialização, maior o risco. É por isso que se diz que o risco do negócio aumentou após a granelização de coleta.

Os investimentos feitos em melhoramento da infra-estrutura, na aquisição de tanques e de ordenhadeiras mecânicas, e em abrigo nas propriedades, além de possuirem um alto custo (como mostrado nas tabelas da seção 6.1), são muito específicos à atividade leiteira. Dessa forma, observou-se que a especificidade dedicada na transação é alta, tanto para pequenos, quanto para médios e grandes produtores. Ou seja, caso o negócio venha a ser desfeito, a alta especificidade dedicada dos ativos traria custos irrecuperáveis para estes 
agentes.

A especificidade física diz respeito ao tamanho (ou capacidade, em litros) dos tanques instalados nas propriedades rurais. A capacidade do tanque utilizado deve ser duas vezes o volume de leite que o produtor obtém ao dia e mais uma sobra. Isto se deve ao fato de que a coleta em dias alternados permite que o leite de duas ordenhas seja armazenado frio. Além disso, o tanque com a capacidade um pouco maior que o comumente produzido por dia funciona como um estímulo visual ao produtor. A idéia é despertar no produtor que, à medida que ele melhore suas técnicas de manejo do gado e conseguir aumentar seu volume de produção diário, ele se apropriará de economias em escala, favoráveis ao crescimento da sua renda mensal.

As entrevistas também permitiram observar que os produtores estão comprometidos com o processo de granelização, dado que estão cientes das crescentes pressões concorrenciais sobre a qualidade do leite. Nesse sentido, eles reconhecem que a especialização é a única alternativa para permanecerem na atividade e ampliarem sua renda. Caso contrário, a exclusão da atividade seria a conseqüência inevitável com o desenvolvimento do processo.

Por conseguinte, a maioria dos produtores entrevistados afirmaram que não deixariam de entregar seu leite ao laticinio em questão, mesmo em condições temporariamente favoráveis, pois eles sabem que correriam o risco da não continuidade de tais condições. Ainda que em condições de incerteza sobre o preço que receberão pelo leite após 30 dias da entrega (prazo em que é feito o pagamento), os produtores se sentem certos de que vão receber o que Ihes é devido, fato que não acontece normalmente com alguns produtores que transacionam, ou que já transacionaram, com outras cooperativas ou multinacionais na região.

A maioria (99\%) dos produtores, tanto os pequenos quanto os médios, também afirmou que não desejaria que existisse contrato formal para a compra 
e venda de leite. Segundo eles, a formalização da relação via contrato não acrescentaria mais certeza ao negócio. Ao contrário, eles temem que contratos formais poderiam vir a estipular exigências e controles sobre a matéria-prima que, talvez, eles não tivessem como cumprir.

Os produtores também estão cientes de que a refrigeração imediatamente após a ordenha aumenta a vida útil do leite e evita a proliferação de bactérias, fato que confere diminuição de sua perecibilidade ou especificidade temporal. Consequentemente, produtor não precisa ficar preso ao municipio para vender seu leite. Eles podem negociar com outros laticinios em regiões vizinhas caso o atual laticínio feche ou desfaça o acordo de compra de leite. A captação a granel permite que ele ofereça seu produto em até $200 \mathrm{Km}$ de distância da sede produtiva (segundo informações do técnico), razão de a especificidade locacional ser considerada baixa.

Os grandes produtores, por sua vez, mais tecnificados gerencialmente e com produção um pouco mais especializada que os menores, gostariam que existisse uma formalização contratual. Eles têm consciência de que o sistema segue em direção a pagamentos que premiem volume, contagem de células somáticas e percentual de gordura, o que os privilegiaria com preços melhores. Outro aspecto observado segundo seus interesses é que os contratos teriam a finalidade de, não somente premiar os aspectos acima, mas também, formalizariam as relações, servindo como garantia de que o laticínio (ou a empresa responsável) não voltaria a negociar com safristas em momentos de oscilações bruscas nos preços do leite ou de seus derivados.

A racionalidade e o oportunismo são pressupostos comportamentais dos agentes e não interferem diretamente na definição da estrutura de gestão da transação. Porém são aspectos a serem considerados quanto à força que a relação contratual entre produtor e indústria venha a assumir. A fragilidade destes pressupostos nos comportamentos dos agentes nas relações determina as possiveis quebras contratuais. Sendo assim, a forma como o 
comportamento e a reputação moral dos agentes influenciam suas decisões é tão importante quanto a forma de governança adotada na relação.

Tal realidade, observada a partir de entrevistas diretas, permite inferir que, sob o ponto de vista dos produtores, as transações tendem a continuar funcionando baseadas somente na confiança entre as partes contratantes. Esta afirmativa é corroborada pelo fato de que a estratégia da empresa laticinista na região estudada é fortificar as relações com produtores menores como forma de evitar evasão no fornecimento de leite, caso haja alguma situação oportuna, como por exemplo a entrada de novas empresas concorrentes no negócio.

A mesma transação também foi analisada sob o ponto de vista da empresa laticinista, segundo sua posição de compradora de matéria-prima (leite) para o processamento de derivados.

$O$ atributo freqüência da transação diz respeito à freqüencia em que a coleta de leite é feita pela indústria, o que foi verificado ser indiferente, pois os caminhões efetuam o trabalho de coleta todos os dias. Entretanto, a vantagem da coleta em dias alternados está na racionalização de rotas, que faz com que não seja necessário passar pelas mesmas propriedades rurais todos os dias. Isto garante à indústria uma economia em quilômetros percorridos, em manutençäo e em reparo dos caminhões, em gastos com combustivel, em número de carreteiros contratados, e, consequentemente, em pagamentos pelos seus serviços.

Os riscos associados ao negócio são os mesmos que os do produtor, com o agravante que são antecipados pela indústria. Além disso, a indústria, ao incentivar o produtor a se modernizar, está, indiretamente, contribuindo para que no futuro ele seja mais independente, visto que ele poderá negociar à distância com outro agente. O que faz com que estes agentes não se distanciem são os vinculos e a fidelidade, estabelecidos durante o processo de implantação da coleta a granel do leite. Além disso, a confiança reciproca na reputação moral dos agentes também assegura a continuidade das transações. 
Os altos custos iniciais com a aquisição de tanques de expansão, adaptação dos caminhões para o transporte do leite refrigerado, construção de abrigos para os resfriadores nas propriedades rurais, mapeamento de rotas, entre outros gastos em infra-estrutura e com a implantação do processo, mostram o quão dedicada é a especificidade desta modernização produtiva para a empresa.

Diretamente relacionada à alta especificidade dedicada na transação está a especificidade humana. À medida que o processo avança ele exige aprendizado e aperfeiçoamento técnico de todos os agentes envolvidos. A especificidade locacional, neste caso, é um encadeamento da especificidade humana. Para a indústria é importante que ela mantenha uma infra-estrutura de processamento de leite, ou fábrica ${ }^{22}$, localizada próxima à região de produção leiteira. É através deste suporte operacional que ela possibilita assistência técnica aos produtores bem como os mantém informados sobre os testes efetuados no leite e o seu respectivo preço.

A especificidade física é vista pela indústria como uma forma de estimular a ampliação da capacidade produtiva nas propriedade rurais. É considerada alta, pois a indústria faz o financiamento do tanque com capacidade um pouco maior que suficiente para armazenar o volume diário de leite. Além disso, a indústria viabiliza a aquisição de tanques maiores, possibilitando o resfriamento conjunto do leite de micro produtores cujas sedes leiteiras encontrem-se num raio de, no máximo, um quilômetro de distância uns dos outros ("condomínio de produtores"). Esta foi uma alternativa criada pela indústria para propiciar a especialização produtiva ao maior número possivel de produtores, inclusive aqueles que não tivessem escala suficiente para adquirir um resfriador ou que não contassem com a infra-estrutura necessária (energia elétrica) na

\footnotetext{
${ }^{22}$ Muitos postos de resfriamento foram desativados após a granelização da coleta de leite, que passou a ser entregue frio. Entretanto, as fábricas ou laticinios permanecem em operação, mesmo porque elas representam uma forma de controle e de proximidade da indústria com os seus fornecedores de leite.
} 
propriedade.

Quanto à percepção comportamental da indústria na transação, observouse a mesma dispõe de informações sobre o funcionamento do processo de coleta a granel através de exemplos de outros países onde a pecuária leiteira já tenha passado por esta fase. Além disso, ela conhece o perfil do seu fornecedor, suas práticas e aptidões empreendedoras. O oportunismo por parte da indústria é praticamente inexistente, pois para ela é indiferente trocar um produtor por outro. Ela apenas o fará se o produtor resistir à modernização ou se depois de quitar suas obrigações com a aquisição do resfriador ele decidir comercializar com outro agente ou resolver abandonar a atividade.

Embora a implantação do processo de granelização da coleta de leite tenha exigido inversões específicas, a especificidade temporal, ao contrário das demais, foi diminuída após a operacionalização do mesmo. Ou seja, com o resfriamento do leite a sua perecibilidade ficou muito menor, como também ficou menor a proliferação de bactérias e perdas com leite contaminado ou ácido. Para a indústria isto significou melhor rendimento industrial e, para o produtor, um fator a mais de segurança na transação.

Analisando-se a transação segundo os depoimentos dos agentes que representam a indústria no caso em estudo, vê-se que, mesmo que o resfriamento do leite propicie maior autonomia aos produtores - e portanto, maior independência, a indústria ainda não está apta a propor uma contratação formal com os seus fornecedores de leite.

Segundo proposto no referencial teórico, o alinhamento das estruturas de governança é condicionado por três grupos de fatores: características das transações, pressupostos comportamentais dos agentes e ambiente institucional. Apesar das especificidades da transação terem sido aumentadas de um modo geral e dos comportamentos dos agentes terem sido redirecionados pela confiança mútua, não houve uma mudança fundamental nas relações econômicas normativas, ou seja, no ambiente institucional. 
Nesse sentido, embora a granelização da coleta seja parte de um processo de modernização da pecuária leiteira, as especificidades trazidas à matéria-prima leite quando da sua implantação não foram suficientemente capazes de modificar a forma de governança adotada entre produtor e indústria de leite.

Como o mercado doméstico é o formador de preços do produto, e está sujeito às flutuações na oferta oriundas das importações de lácteos e dos constantes desbalanços entre oferta e demanda doméstica, a indústria não pode firmar antecipadamente nem o volume nem o preço do produto a ser adquirido por cerca de um ano, por exemplo. Ela também está sujeita às oscilações do mercado bem como sujeita às variações na venda de seus produtos. Por outro lado, a indústria garante pagamento adicional aos produtores que fornecerem leite resfriado e oferta regular ao longo do ano. Este pagamento representa uma taxa de granelização, que corresponde a $3 \%$ do preço do litro de leite, como forma de incentivar os produtores na fase inicial do processo.

Outra questão que suprime, por enquanto, a importância do contrato escrito é a garantia que a empresa oferece aos produtores quanto à sua idoneidade, suporte organizacional e reputação moral.

Retomando o problema em estudo, a questão que se tem é que tipo de produtor deverá permanecer na atividade leiteira e qual será a nova relação entre ele e a indústria após concretizado o processo de granelização da coleta de leite?

Segundo o gerente responsável da empresa pela compra de leite, os produtores mais fiéis são os pequenos, que também representam a grande maioria dos seus fornecedores de matéria-prima. O comprometimento destes produtores está fortemente relacionado com a sua dependência em relação à indústria (unidade processadora na bacia leiteira) para atingir o mercado, ou como meio de conseguir financiamentos para o seu negócio. Sua fidelidade, 
pois, é a expressão do seu compromisso com a empresa neste processo de modernização da atividade leiteira e da progressiva melhoria da qualidade do leite.

Os grandes produtores, como dispõem de uma capacidade maior de barganha, são mais passiveis de ações oportunistas de parte a parte. Devido ao grande volume de leite que negociam, eles estão aptos a usufruir de vantagens de preço com outro laticinio ou cooperativa.

Os médios produtores, por sua vez, não estão comprometidos com a atividade leiteira. Geralmente, a familia destes produtores mora na cidade e a principal fonte de renda não é a pecuária leiteira, ela funciona apenas como um apêndice. Sendo assim, esta classe de produtores ou a maioria deles, não está disposta a investir grandes somas num negócio que lhes é secundário em termos de geração de receitas. Estes serão os primeiros produtores a abandonar a atividade leiteira, ou pelo menos parte dela, devido às exigências em especialização dos meios de produção. Alguns deixarão de ser "tiradores" de leite e poderão se dedicar, simplesmente, à produção de alimento para o gado ou se ligar a qualquer outra atividade sinérgica à pecuária leiteira.

Os grandes produtores, em menor número na região estudada, apresentam uma tendência de deslocamento indiferente na contabilização final do processo de modernização da atividade leiteira. Boa parte deles deverá permanecer na atividade, porém dedicando-se àquilo em que são mais eficientes, seja em recria e melhoramento de animais, fornecedores de alimentos para o gado ou como produtores de leite.

Com os pequenos produtores também deverá ocorrer algum deslocamento entre as atividades que envolvem a produção de leite. Alguns abandonarão de fato a atividade, seja porque não tiveram como acompanhar o desenvolvimento do processo de seleção que a granelização da coleta de leite impôs, seja porque foram excluidos quando feito o mapeamento das rotas. Aqueles que foram alienados do processo, ou se dedicarão à simples 
subsistência, ou se empregarão em outras fazendas mais desenvolvidas na produção leiteira.

Um outro grupo de pequenos produtores se associará com outros pequenos produtores, formando "condomínios de produção de leite". Por meio destes condomínios eles conseguirão dividir os custos iniciais do investimento que o processo de coleta a granel de leite refrigerado exige, bem como outros custos que se fizerem necessários. Consequentemente, eles se beneficiarão conjuntamente com a receita obtida a partir dos ganhos em economias de escala que auferirem com a associação.

O responsável pela empresa na região estudada afirma que estes serão os seus principais fornecedores de matéria-prima e credita total apoio à sua associação. A exigência da empresa é que os associados tenham conhecimento um do rebanho do outro e da saúde de suas vacas, a fim de que não se misturem leites de padrões diferentes de qualidade. A mistura de leites de diferentes padrões microbiológicos e físico-químicos nos resfriadores nivela a qualidade do leite ao mínimo, dificultando a homogeneização dos padrões de qualidade do mesmo. 


\section{CONCLuSÕes}

Diante da nova realidade brasileira e do nivel de desenvolvimento que a pecuária leiteira nacional apresenta, o atual processo de seleção de produtores ante a granelização da coleta de leite representa um primeiro passo fundamental em termos de modernização da pecuária leiteira, consonante com mudanças ocorridas em décadas anteriores em outros países, conforme apontado no capítulo 4. Países como os Estados Unidos, o Reino Unido e a Nova Zelândia, que hoje encontram-se em processo avançado de organização da produção primária e da comercialização de leite, também passaram por fases semelhantes de aprendizado e profissionalização nas relações e negociações entre os agentes da cadeia agroindustrial. No Brasil, estas fases foram atropeladas e, hoje, a coleta a granel de leite refrigerado representa um novo paradigma de desenvolvimento do setor, ressaltando a urgência de reformar os atuais padrōes de qualidade do leite de consumo e industrial.

$\mathrm{Na}$ década de 90 ocorreram quatro mudanças fundamentais no contexto da economia brasileira e que tiveram repercussões diretas sobre o setor leiteiro. São elas: a integração do Mercosul e a consolidação da abertura comercial em 1990, a desregulamentação dos preços do leite em 1991, a estabilidade monetária em 1994 e a granelização da coleta de leite a partir de 1995/96. Esta última mudança estrutural será tão importante para o setor quanto foi a desregulamentação no início da d, incentivando progressivamente a modernização de práticas de manejo do rebanho e de conservação do leite.

Para que todo o processo de granelização se concretize, a próxima fase a 
ser transposta é a revisão das normas oficiais de produção e a melhoria da fiscalização e controle do cumprimento destas normas por parte dos agentes governamentais. As normas de produção são importantes para que se estabeleçam parâmetros e critérios sobre o nivel básico de aceitação do leite produzido, em termos de qualidade e sanidade, como acontece nos países desenvolvidos. As normas de produção têm relação com a proteção da saúde do consumidor final, em termos de leite fluido e derivados. Igualmente importante é a fiscalização do governo federal sobre o cumprimento das normas de produção e processamento do leite. Além disso, o controle é importante para se conhecer as necessidades dos segmentos produtivos e, consequentemente, para traçar políticas de apoio ao setor leiteiro no País.

Antes que estes critérios estejam definidos e sendo cumpridos, não há como tratar as relações entre produtor e indústria de outra forma que não seja somente por meio do comprometimento e da fidelidade. Dessa forma, observase que a hipótese do estudo foi refutada com a investigação da pesquisa de campo. Não se pode negar, contudo, a importância que a coleta a granel de leite frio teve em aproximar os agentes e criar vínculos entre eles. A granelização da coleta propiciou a redução dos custos de produção, principalmente na parte do transporte de primeiro percurso.

Apesar do aumento das especificidades da matéria-prima leite, da aproximação dos agentes e do conseqüente comprometimento entre eles, a eficiência contratual ainda não foi plenamente atingida devido à inexistência do ajuste de normas e regulamentação dos critérios de qualidade do leite no País. Ou seja, não houve uma mudança fundamental nas relações econômicas que configuram o ambiente institucional no qual as transaçōes estão inseridas. Além disso, também não houve uma mudança fundamental nos padrões de competitividade do mercado, como aqueles que caracterizaram grandes mudanças na economia leiteira dos Estados Unidos ao longo do século XX.

Acredita-se que determinados produtores, mais especializados e com 
maior volume de produção, devam, no futuro próximo, firmar algum tipo de contrato mais formal com a indústria. Entretanto, a velocidade com que estas mudanças na estrutura de governança deverão ocorrer vai depender da especificidade futura da matéria-prima resfriada, da velocidade de generalização do processo de granelização da coleta e também da homogeneização dos niveis de qualidade do leite em termos nacionais. Uma condição necessária para a efetivação contratual seria o empenho de todas as outras empresas e produtores de leite do País no processo de modernização produtiva e de melhoria da qualidade do leite. A condição suficiente seria, por conseguinte, a revisão de novas normas e padrões de produção e sua efetiva fiscalização ao longo da cadeia láctea.

O que se presume é que só serão formalizados contratos entre produtor e indústria de leite quando houver um sistema dominante de produção de leite a partir de produtores profissionalizados que se preocupem de fato com os riscos e variações sazonais de preços, a homogeneidade do leite produzido em termos de qualidade e, consequentemente, pressionem a indústria no sentido de cumprir sistemas mais rígidos de pagamento por volume e qualidade.

Assim, pode-se concluir que a mudança na estrutura de governança entre produtor indústria ainda não se configura na forma contratual em virtude das disparidades na caracterização do rebanho e do seu manejo entre os diversos produtores, e, principalmente, na falta de um conjunto de políticas, ações e regulamentações modernas sobre a atividade produtiva leiteira como um todo. As relações contratuais entre os referidos agentes situam-se numa forma mista, entre o mercado e os contratos, onde existem vínculos e comprometimentos, mas não há garantia ou salvaguarda, de nenhuma das partes, que evite uma possivel quebra contratual, como também não se tem configurado sistemas de arbitragem que regulamentem as especificidades do produto transacionado.

Seguindo a mesma linha teórica de análise do problema em estudo, configuram-se duas possiveis propostas para pesquisas futuras: 
- Após satisfeitas todas as etapas necessárias para a concretização da granelização da coleta de leite e de modernização da pecuária leiteira nacional, qual será o novo perfil técnico-econômico de produtores que serão procurados pelas visando atender aos critérios de máxima eficiência econômica e contratual com a indústria?

- Na área social, fica a questão de identificar qual será o futuro dos produtores de leite marginalizados com a intensa seleção imposta pelo processo de coleta a granel de leite refrigerado? 
ANEXO A 
Atualmente a avaliação da qualidade do leite in natura, no Brasil, segue três parâmetros:

a)parâmetros físico-químicos

Alizarol - estima a estabilidade das caseínas ao calor. O teste pode ser realizado com diferentes concentrações de álcool e de acordo com o resultado, pode-se determinar o limite de temperatura que o leite pode suportar. É um teste rápido e prático para a classificação do leite durante a recepção.

Gordura - é um componente do leite que tem grande importância do ponto de vista nutricional. Apresenta-se no leite com concentrações entre 3,2 a $3,9 \%(\mathrm{~m} / \mathrm{v})$. Existe uma uniformidade na concentração de gordura quando comparadas vacas de mesma raça com dietas semelhantes, no entanto, há uma grande variação no teor de gordura quando comparados animais de raças diferentes (Jersey $4,4 \%(\mathrm{~m} / \mathrm{v})$, Holandês $(\mathrm{m} / \mathrm{v}))$. O teste feito é o de densidade, relação massa/volume. No caso do leite a densidade normal varia de 1,027 a 1,033 , porque este produto apresenta vários componentes diluídos ou não em água que apresentam densidades variáveis. Destes, a gordura do leite é o único elemento que apresenta densidade menor do que a da água (que é 1). Os demais componentes do leite apresentam todos densidade acima de 1 . Desta forma, uma densidade abaixo dos niveis normais pode indicar adição de água, ou seja, uma maior aproximação da densidade 1. Já um valor acima dos parâmetros normais indica, provavelmente, um leite com valores extremamente baixos de gordura ou fraude por desnate do produto.

Extrato seco desengordurado - refere-se ao extrato seco total menos a gordura. Em termos de nutrição, o principal fator associado à variação no ESD é o nivel de energia da dieta. Ao contrário do que pode parecer, o aumento no nivel de proteína da dieta acima das recomendações do NRC não determina 
um aumento no teor de proteina do leite.

Um outro aspecto a destacar é a passagem dos animais para o sistema de pastejo. Caso os animais estejam recebendo uma dieta deficiente em energia, ao mudar para o sistema de pasto, pode acarretar um aumento no ESD. Por outro lado, se os animais estiverem recebendo mais de $130 \%$ do recomendado em energia, a mudança para pasto pode acarretar uma queda no ESD.

A qualidade da forragem é um outro fator responsável pela variação no teor de ESD. O uso de forragem de alta qualidade, que apresentem alta digestibilidade e proporcionem alta ingestão de matéria seca, tende a favorecer um aumento no ESD. O feno de baixa qualidade tende a diminuir O ESD.

Com relação à idade, nota-se que o nivel de ESD diminui à medida que o animal envelhece. E no verão o ESD é menor do que no inverno.

Acidez - esse aspecto pode se medido por PH ou por titulação com solução de hidróxido de sódio (Dornic). Um leite normal apresenta uma faixa de variação de $\mathrm{PH}$ entre 6,5 e 6,7 e um valor de $16^{\circ}$ a $18^{\circ} \mathrm{D}$ (leite total da fazenda). O teste Dornic tem sido o mais utilizado para avaliação de acidez no leite, com o objetivo de detectar aumento na concentração de ácido lático, uma vez que este ácido é formado pela fermentação dos açúcares do leite, o que traduz uma qualidade microbiológica inadequada da matéria-prima.

Uma elevada acidez (baixo $\mathrm{PH}$ ) no leite pode estar relacionada com o desenvolvimento de microorganismos acidificantes. Além disso, pode ser decorrente de elevados niveis de proteina no leite (leite de vacas Jersey são mais ácidos devido ao maior teor de proteínas), ou incorporação de $\mathrm{CO}_{2}$ no leite durante a ordenha. Uma baixa acidez, ou alto $\mathrm{PH}$, no leite pode estar relacionada com a ocorrência de mastite no animal, devido aos componentes do sangue que passam diretamente para o leite.

Proteínas - O leite é uma fonte reconhecida de proteínas com alto valor 
biológico. Tecnologicamente, as proteínas lácteas apresentam importantes propriedades funcionais, além de influenciarem diretamente no rendimento industrial. Para fins de pagamento pela qualidade, deve-se optar pelo teor de proteina verdadeira (proteína total menos nitrogênio não protéico) ou teor de caseina, sendo este último o indicado para fábricas de queijo.

Crioscopia - O ponto crioscópico nada mais é do que a temperatura de congelamento do leite. Esse valor varia normalmente entre $-0,535$ e $-0,5510 \mathrm{C}$, ou seja, o leite congela a uma temperatura inferior à da água. Desta forma, a determinação do ponto de congelamento permite a detecção de adição de água no leite. Cabe ressaltar que somente os componentes solúveis em água interferem no ponto crioscópico, assim, a proteina e a gordura não determinam variação nesse índice. Sendo assim, o desnate não altera o índice crioscópico.

O principal objetivo deste teste é avaliar se houve adição de água no leite - por fraude ou acidentalmente (resíduo de água nos latões, drenagem mal feita do sistema de ordenha, água em tanques de resfriamento) - pois nesse caso haverá uma maior diluição dos componentes solúveis, e o ponto de congelamento do leite tende a se aproximar do ponto de congelamento da água.

Lactofiltração - Teste que evidencia uma contaminação grosseira e macroscópica do leite. Pode detectar uma infecção severa do úbere (mastite) pela retenção de pus sobre a superfície filtrante.

b) parâmetros microbiológicos

Em termos de padrão microbiológico existem dois testes bastante tradicionais que são a contagem bacteriana total (CBT), ou contagem global, e a redutase. A redutase é um teste baseado na redução, ou desaparecimento, do corante azul de metileno em um leite incubado. Quanto maior a carga microbiana do leite, maior potencial de redução (descoloração) do azul de 
metileno. Entretanto, bactérias diferentes têm comportamentos diferentes frente à redução do corante. Desta forma, não se pode extrair conclusões sobre a natureza da contaminação, e nem relacionar a ocorrência de mastite com a CBT do leite, isso porque o número de colônias $/ \mathrm{ml}$ dos microorganismos causadores de mastite é bastante baixo. Geralmente este teste é aplicado para leite entregue em latões.

A contagem global é um teste mais exato, que apresenta numericamente a contaminação bacteriana do leite. Como ideal, este valor deve ficar abaixo de $100.000 \mathrm{col} / \mathrm{ml}$. Existem dois fatores responsáveis pela contagem bacteriana do leite: a carga microbiana inicial e o sistema de resfriamento do leite. A carga microbiana inicial está diretamente associada à limpeza dos utensilios utilizados para retirada e transporte do leite. Dessa forma a higienização dos baldes, latões e sistemas de ordenha são os principais fatores responsáveis pela produção de um leite de alta qualidade microbiológica. A qualidade da água utilizada para lavagem dos utensilios e equipamentos de ordenha e tetos dos animais tem um papel bastante importante. O sistema de resfriamento do leite, por outro lado, determina as condições de armazenamento e transporte do leite, que deve ser bem aprimorado, visto que há algumas bactérias que ficam na superfície dos tetos que são capazes de se multiplicarem mesmo em baixas temperaturas.

Laranja (1996) adverte, que para se manter um bom padrão microbiológico, deve-se atentar para os aspectos ligados à extração e ao armazenamento do leite. $E$ acrescenta que $95 \%$ dos problemas de alta CBT são originários de deficiência na lavagem e sanitização de utensílios e sistemas de ordenha, associados a problemas de resfriamento, e raramente a vaca é a fonte do problema.

c) parâmetros sanitários 
A principal preocupação sob este aspecto é a mastite, que é a infecção do úbere caracterizada por um aumento das células somáticas no leite.

Os métodos utilizados para detectar tal problema são a contagem ao microscópio, ou métodos automatizados, também denominado método direto, e contagem de células somáticas (CCS), ou verificação da viscosidade resultante da mistura de um detergente com o leite (método indireto). Os testes usuais são: CMT (Califórnia Mastitis Test), WMT (Wisconsin Mastitis Test) e Whiteside. O número aceitável de CCS na coleta do leite é de 200.000 a 500.000 no Brasil, recebendo uma bonificação o produtor que apresentar o produto com menos de 200.000 células somáticas. Nos Estados Unidos, por exemplo, é comum em muitas fazendas a CCS ser de 100.000 a 200.000 .

A qualidade sanitária do leite está diretamente ligada à preocupação com a saúde do consumidor, principalmente no caso de presença de resíduos de antibióticos no leite, decorrentes de animais tratados. 
ANEXO B 


\section{INSTRUMENTO PARTICULAR DE CONTRATO DE COMPRA E VENDA DE LEITE (MODELO)}

Pelo presente instrumento de contrato de compra e venda para fornecimento de leite, de um lado como fornecedor. neste ato representado por brasileiro, casado, portador do RG e CIC. estabelecida a Rua neste ato representada por

seu(s) representantes legal(s) brasileiro, casado, portador do RG e $\mathrm{CIC}$ .doravante denominado LATICINIO, entre si firmam o seguinte:

\section{CLÁUSULA PRIMEIRA - DO OBJETIVO}

1.1. O PRODUTOR compromete-se a entregar sua produção de leite e o LATICiNIO a pagar conforme as cláusulas deste contrato.

1.2. O contrato será para um período de ..... dias a contar da data de assinatura deste contrato, podendo ser revalidado por igual periodo mediante manifestação expressa pelas partes um mês antes do vencimento.

\section{CLÁUSULA SEGUNDA - DAS CONDIÇŌES DE VENDA E FORNECIMENTO}

2.1. O transporte do leite até a plataforma (primeiro percurso) e o segundo percurso correrāo por conta devendo o LATICINIO retirar o leite na propriedade do PRODUTOR.

2.2. A pesagem, a análise e a classificação do leite na plataforma do estabelecimento de recepção, serão feitas de acordo com as normas estabelecidas pela legislação sanitária de produtos de origem animal, podendo ser presenciadas pelo PRODUTOR ou seu representante.

2.3. Fica ajustada multa de ............. à parte que infringir qualquer cláusula deste contrato.

\section{CLÁUSULA TERCEIRA - DO PRECCO}

3.1. O preço a ser pago ao PRODUTOR, tendo sempre como unidade um litro, corresponderá a ...........

3.2. O LATICÍNIO efetuará os descontos das contribuições legais e aquelas que o PRODUTOR venha a indicar

3.3. O pagamento do leite ao PRODUTOR será realizado todo dia ...... do mês seguinte a entrega.

3.4. Se houver atraso nos dias de pagamento por parte da USINA, esta incorrerá em multa de .......\%.

3.5. Caso o atraso ou qualquer pagamento ultrapasse .......dias úteis estará configurada quebra de cláusula contratual.

3.6. O LATICINIO adiantará ao PRODUTOR, no dia primeiro do mês seguinte ao da entrega, ....\% do pagamento do mês anterior.

\section{CLÁUSULA QUARTA - DAS CONDIÇÕES GERAIS}

4.1. O PRODUTOR arcará com todos os encargos tributários, impostos, taxas e/ou demais contribuiçōes legais que the couber, que serão recolhidos pelo LATICINIO aos órgãos competentes.

4.2. Qualquer tolerância pelas partes, relativamente ao cumprimento das obrigaçōes assumidas neste instrumento, não importará em inovação ou alteraçāo contratual, tácita ou expressa, nem inibirá a exigência dos demais direitos oriundos deste contrato.

4.3. Ficam pactuadas expressamente as cláusulas de irrevogabilidade e irretratividade por forças das quais nāo é lícito o arrependimento a nenhuma das partes, nem a seus sucessores.

4.4 Fica eleito o foro da comarca de ................, onde se encontra instalado o estabelecimento de laticinios da USINA, com exclusão de qualquer outro, por mais privilegiado que seja, para dirimir quaisquer pendências oriundas deste contrato.

4.5. O rompimento do contrato poderá ser feito por qualquer das partes mediante manifestação expressa com antecedência de .... dias.

E, por assim haverem contratado, assinam este instrumento em três vias de igual teor, para um só efeito, perante as duas testemunhas abaixo.

Data:.....................
PRODUTOR
LATICINIO
TESTEMUNHAT
TESTEMUNHA2

Fonte: Anuário Milkbizz, 1997, p. 22 
ANEXO C 


\section{QUESTIONÁRIO}

LINHA (granelizada ou não)

NOME DO PRODUTOR:

NOME DA PROPRIEDADE:

TAMANHO (ha):

ATIVIDADES (por ordem de importância):

1)

2)

3)

4)

ATIVIDADE LEITEIRA:

Produção média diária

№ vacas lactação

I/dia

№ vacas total animais

Sistema de criação animais

1)Por que o senhor não granelizou ainda?

( ) falta de incentivos

( ) não acredita no processo

( ) outros

2)Avaliação Quantitativa da Granelização:

\begin{tabular}{l|l|l} 
VARIÁVEIS & ANTES (latões) & DEPOIS (granel) \\
\hline Volume/dia & & \\
\hline Cota/extracota & & \\
\hline $\begin{array}{l}\text { Custos fretes do } 1^{\circ} \\
\text { percurso }\end{array}$ & & \\
\hline Preço médio recebido/l & & \\
\hline Adicional por qualidade & & \\
\hline Outros adicionais de preço & &
\end{tabular}

3)AVALIAÇÃo Qualitativa dA GRANELIZAÇÃo:

a) Fatores impulsionadores:

( ) concorrência com leite ( ) expectativa de () redução de perdas 
resfriado

melhoria do preço

por acidez

recebido

( ) redução de custos de

( )humaniz. do trabalho

( ) todos

frete

( ) outros:

b) Benefícios ou ganhos trazidos com a granelização:

c) Dificuldades ou perdas:

RELAÇÕES PRODUTOR/INDÚSTRIA

4) Como estão estabelecidas suas relações de compra e venda de leite com a indústria?

( )promessa/confiança ( )contrato escrito

$E$ isto garante o funcionamento da relação?

( ) sim ( )não

5) Como é definido o preço?

( ) mercado ( )combinado por um ( ) pela qualidade do seu período pré-estabelecido leite

( ) pela regularidade na ( ) pelo seu volume ( ) todos entrega

6) Em situações convenientes - adicionais de preço, por exemplo - o senhor entregaria seu produto a outra unidade industrial, laticínio ou cooperativa? $E$ após a coleta a granel?
( ) sim
( )não

7) Estas situações ocorrem com que freqüência?
( )sempre
( )raramente
( )não ocorrem comigo

8) Cite dois exemplos destas situações: 
9) Qual era a freqüência da coleta de leite antes do resfriamento na fazenda?

( )todo dia ( )dias alternados

E depois do resfriamento?

( )todo dia ( )dias alternados

10) Em que aspectos o senhor se sente mais vulnerável ou dependente na relação com a indústria?

11) Após adaptado ao sistema de coleta a granel, que garantias o senhor tem sobre a manutenção da relação com a indústria na venda de leite?

12) Se, após feitos todos os investimentos necessários para a coleta a granel de leite refrigerado, o senhor não se sentir satisfeito ou resolver mudar de negócio, tem como vender o resfriador e demais ativos e recuperar o investimento?
( ) $\operatorname{sim}$
( ) não

13) Se o senhor não estiver satisfeito, por algum motivo - preço, exigências de qualidade e normas - com a relação com a indústria, há como entregar o seu leite para outra unidade industrial e ser valorizado pelo uso do resfriamento do leite?
( ) sim
( )não

14) Antes das exigências do resfriamento do leite para a coleta a granel a atividade de produtor de leite exigia outros investimentos além da simples tiragem e entrega de leite?
( ) sim
( )não

15) Avaliação regional - melhorias e problemas que surgiram na região com a coleta a granel.

\section{AVALIAÇÃO DA QUALIDADE}

16) O senhor sabe como é feita a análise da qualidade? 
17) Existe a possibilidade de conferir o resultado - caso o senhor não concorde - sem abalar a relação?

18) Como o senhor percebe (ou se beneficia) os sistemas de bonificação por qualidade, volume e regularidade do leite entregue?

\section{UNIDADE INDUSTRIAL}

1) Quantos litros de leite são captados por dia? Quantos por cento de sua coleta de leite já é granelizada? Em quanto tempo se prevê granelizar $100 \%$ ?

2) Quantos por cento dos seus fornecedores de leite largaram a atividade com a implantação da coleta a granel? Quantos por cento não quiseram granelizar?

3) Se o produtor não quiser granelizar, ele sai da relação com a indústria? Em quanto tempo?

4) Quais os procedimentos básicos para se instalar a granelização de um linha de coleta de leite? (mapeamento das rotas, financiamento de resfriadores, aquisição de tanques isotérmicos, pagamento por qualidade do leite, bonificação aos transportadores, etc.)

5) E qual a sua importância na redução de custos?

6) Qual é a soma dos investimentos realizados em média numa linha para ser granelizada? Qual é a principal forma de financiamento e de amortização da dívida, inclusive tempo para isto?

7) Quadro comparativo de recolha do leite a granel e em latões:

\begin{tabular}{l|l|l|l} 
ITENS & EM LATÕES & A GRANEL & VARIAÇÃO (\%) \\
\hline Periodo & Jul/95 & Mar/98 & - \\
\hline Recepção de leite (I) & & & \\
\hline$\%$ recolha do leite & & & \\
\hline № de produtores & & & \\
\hline Média I/dia/produtor & & & \\
\hline № unid. Resfriamento & & & \\
\hline Custos frete 1\% percurs. & & &
\end{tabular}




\begin{tabular}{l|l|l|l} 
Custos frete $2^{\circ}$ percurs. & & & \\
\hline № de linhas de leite & & & \\
\hline №- de veículos & & & \\
\hline $\begin{array}{l}\text { № pessoas no } \\
\text { transporte }\end{array}$ & & & \\
\hline № viagens/dia & & & \\
\hline Vol. médio/veículo (I) & & & \\
\hline Vol. médio/viagem (I) & & & \\
\hline Temp. média leite $\left({ }^{\circ} \mathrm{C}\right)$ & & & \\
\hline Qualidade do leite & & & \\
\hline № colaboradores & & &
\end{tabular}

\section{AVALIAÇÃO DA QUALIDADE}

8) Como funciona o sistema de pagamento por qualidade? Quais os critérios? (pagamento por qualidade, volume e regularidade) É semelhante ao de outros SAG's ou de outros países?

9)Se o produtor desconfiar do resultado, há como conferir o teste sem abalar a relação?

\section{AVALIAÇÃO DA RELAÇÃO PRODUTOR/INDÚSTRIA}

10) Que tipo de incentivos são oferecidos por esta empresa à especialização dos produtores de leite? Como é feito o controle ou monitoramento?

11) O senhor espera que com a coleta a granel de leite refrigerado aumente os vínculos de fidelidade, comprometimento, melhorias crescentes no processo produtivo e industrial, e maior coordenação nas relações entre produtor e indústria? (outros vínculos)
( ) sim
( )não
( ) talvez

Por quê?

12)Em que aspectos o senhor se sente mais vulnerável ou dependente na relação com o produtor?

13) E a indústria, após ter sido ressarcida pelo financiamento ao produtor, que garantias ela tem que o produtor continuará lhe entregando o seu leite? 
14) Por outro lado, existe a possibilidade de o senhor ser deixado na mão pelo produtor? Em que circunstâncias? Acontece com que freqüência?

15)Existe a possibilidade de a indústria mudar repentinamente de fornecedor de leite caso the seja conveniente? Em que circunstâncias isso ocorre? Qual a freqüência?

16) Qual o maior beneficio que a mudança nos sistema de coleta trouxe para a indústria, em ordem de importância.

( )melhoria do rendimento industrial

( )redução de custos operacionais (energia elétrica e transporte) para a fábrica

( ) maior controle sobre a qualidade do leite

17) Expectativas futuras:

( ) ordenha mecânica ( )controle sanitário do rebanho

( ) melhor conserv. das estradas

( )profissionalização da atividade produtiva
( )melhoramento genético do gado
( ) melhoria das pastagens

( )melhoramento do manejo

\section{EMPRESA (administrativo)}

1) Que fatores influenciaram, e como, a intensificação da coleta a granel de leite refrigerado por esta empresa?

2) O que a empresa conhece sobre a coleta a granel e seus impactos econômicos e sociais no setor leiteiro nos Estados Unidos, Inglaterra e outros países onde a mesma já tenha se concretizado?

3) O que a coleta a granel trouxe de mais importante para a empresa sob o ponto de vista econômico?

4) Qual o perfil do produtores que permaneceram na atividade e que tendem a se especializarem e a se desenvolverem com o processo de coleta a granel?

5) Como o senhor acha que a granelização da coleta de leite pode vir a alterar as relações entre:

a) produtor e indústria

b ) indústria e distribuição/varejo 
6) O que a empresa espera como ação do governo intervindo neste processo? 
ANEXO D 
ANEXO D 


\section{NORMAS PARA COLETA DE LEITE A GRANEL}

A coleta do leite cru a granel (PCG) ou coleta granelizada deverá, obrigatoriamente, ser feita em caminhão-tanque isotérmico, construído internamente de aço inoxidável, dotado de bomba sanitária, acoplável a tanques de expansão. Será admitida a coleta por sucção direta do leite resfriado em latões.

O coletador deverá receber treinamento básico sobre higiene, análises preliminares do produto e coleta de amostras e poderá ser o próprio motorista do carro-tanque.

Serão permitidas coletas simultâneas de leite tipos B e C (mistas) desde que sejam colocadas em compartimentos diferenciados.

O tempo transcorrido entre a ordenha inicial e a coleta do leite deverá ser, no máximo, de 48 horas, tanto para leite tipo $B$ como $C$.

A empresa interessada em realizar coleta à granel deverá implantar um programa de treinamento visando orientar e conscientizar os produtores (proprietários e encarregados) e outras pessoas envolvidas no processo para que a metodologia padronizada pela presente norma, seja rigorosamente aplicada e adotada em todos os segmentos.

1. INSTALAÇÕES E EQUIPAMENTOS

1.1. Leite tipo $B$ - previsto em normas específicas (Portaria $n$ 응 08 SIPA/MA de 26/06/84).

1.2. Leite tipo $\mathrm{C}$

1.2.1. O local de ordenha deverá ser coberto, pavimentado e dotado de 
ponto de água corrente de boa qualidade, mantido em condições adequadas de limpeza;

1.2.2. Deverá existir local próprio e específico para armazenagem do leite mantido sob condições adequadas de limpeza e higiene, atendendo as seguintes exigências:

ser coberto, isolado por paredes, arejado, pavimentado e de fácil acesso ao veículo coletor;

ter iluminação natural e artificial adequadas;

ter ponto de água corrente de boa qualidade, tanque para lavagem de latōes (quando houver) e utensilios de coleta. Junto a esse tanque deverá existir uma bancada para facilitar o manuseio desses utensílios pelo coletador;

os equipamentos de refrigeração utilizados deverão rebaixar e conservar o leite à temperatura prevista nesta norma; os registros de saída dos tanques de expansão deverão ser do mesmo diâmetro das conecções das mangueiras utilizadas para a transferência para o veículo coletor, não sendo permitido o transvase intermediário em latões;

será permitido o uso coletivo de tanques de resfriamento a granel exclusivamente por pequenos produtores de leite tipo $\mathrm{C}$. $\mathrm{O}$ equipamento de resfriamento deverá ser de expansão direta. $O$ volume máximo coletado em conjunto não poderá ser maior que 2.500 litros. A empresa receptora será responsável pela identificação dos usuários do sistema, credenciamento e treinamento de um responsável pela operacionalização da seleção (tomada de higiene do equipamento e do ambiente e entrega ao veículo coletor. 


\section{PROCEDIMENTO DE COLETA}

2.1. A coleta devera ser realizada no local de armazenagem do leite.

2.2. O coletador deverá estar devidamente uniformizado durante a coleta (jaleco limpo e protetor de cabelo).

2.3. Antes do início da coleta, o leite deverá sofrer homogeneização com agitador próprio, tomada da temperatura, realização da prova de alizarol, coleta da amostra, higienização do engate da mangueira e saída do tanque de expansão ou da ponteira coletora (pequeno tubo de aço inoxidável utilizado para succionar o leite dos latões).

2.4. As amostras de leite a serem submetidas às análises laboratoriais de rotina deverão ser transportadas em caixas térmicas higienizáveis contendo gelo.

2.5. A temperatura e o volume do leite deverão ser tomados e anotados em formulários próprios.

2.6. O engate e a ponteira da mangueira deverão ser higienizados após cada uso.

2.7. As amostras das linhas deverão ser coletadas com a freqüencia prevista nas normas vigentes.

2.8. Deverão ser colocados à disposição do coletador os reagentes, soluçöes, detergentes e sanitizantes necessários à sua atividade. 


\section{CONTROLE DO LEITE NO ESTABELECIMENTO PRODUTOR}

3.1. O leite tipo $C$ deverá ser mantido sob refrigeração à temperatura máxima de $7^{\circ} \mathrm{C}$. Admitir-se-á uma tolerância de até $10^{\circ} \mathrm{C}$ durante o período inicial de um ano da operação da coleta.

3.2. O leite tipo $B$ deverá atender às normas em vigor.

3.3. O leite que apresentar qualquer anormalidade não será coletado, devendo ficar na propriedade que o produziu.

3.4. É proibida a coleta de leite à temperatura ambiente (leite quente).

4. TANQUE ISOTÉRMICO DE COLETA A GRANEL

4.1. A mangueira coletora deverá fazer parte dos equipamentos do carrotanque, e no caso da coleta mista, cada produtor de leite B deverá dispor de sua própria mangueira.

4.2. Deverá ser provido de caixa isotérmica de fácil higienização para transporte de amostras e local para guarda dos utensilios e aparelhos utilizados na coleta.

4.3. Deverá ser dotado de dispositivo contendo sanitizante para guarda e proteção, quando não estiver em uso, da ponteira e da régua de medição do volume de leite em latão.

4.4. Deverá ser, obrigatoriamente, submetido à lavagem e higienização após 
cada carregamento.

\section{CONTROLE NO ESTABELECIMENTO RECEPTOR}

5.1. Para qualquer tipo de leite, a temperatura exigida no ato de sua recepção será de, no máximo $10^{\circ} \mathrm{C}$.

5.2. Deverão ser coletadas amostras de cada compartimento dos carrostanque, para análises físico-químicas e microbiológicas.

5.3. Também deverão ser analisadas as amostras colhidas nas propriedades.

5.4. Para recepção no sistema misto, a plataforma deverá descarregar primeiramente o leite tipo $B$ ou efetuar higienização após a recepção do leite tipo $\mathrm{C}$ ou utilizar linhas separadas para a recepção dos leites $\mathrm{C}$ e $\mathrm{B}$.

\section{CONTROLE HIGIÊNICO DA MATÉRIA-PRIMA}

6.1. Para o leite tipo $B$ deverão ser atendidas as normas vigentes.

6.2. Para o leite tipo C:

as amostras colhidas deverão ser submetidas às análises físico-químicas de rotina, pesquisas de conservantes e adulterantes;

deverá ser realizada prova de redutase;

as características físico-químicas e microbiológicas deverão atender aos padrões fixados para cada tipo de leite. 


\section{CONTROLE SANITÁRIO DO REBANHO}

7.1. Para o leite tipo $B$ deverá ser atendido o item 2 das normas vigentes.

7.2. Para o leite tipo $C$ serão exigidas a comprovação anual de negatividade para os testes de Brucelose e Tuberculose.

\section{PROCEDIMENTOS PARA LEITE-PROBLEMA}

8.1. O leite do produtor cujas análises revelarem problemas será, obrigatoriamente, submetido a nova coleta para análises no dia subsequente. Nesse caso, o produtor será comunicado do problema e o leite não será coletado a granel.

8.2. Ficará a critério da empresa retirar esse leite separadamente ou ser entregue pelo próprio produtor diretamente na plataforma de recepção, no horário regulamentar, onde será submetido às análises laboratoriais.

\section{OBRIGAÇÕES DAS EMPRESAS}

9.1. A interessada deverá apresentar projeto ao SIF, detalhando o processo de coleta, incluindo:

produtores - nome, volume e tipo de leite, capacidade dos resfriadores, horário e freqüência de coleta;

rota da linha a ser granelizada apresentando mapas de localização/trajeto e horário provável de chegada no estabelecimento receptor.

9.2. A autorização para ingresso do produtor no Programa de Coleta a Granel (PCG) será dada pela equipe do SIF local, após vistoria das instalações 
envolvidas.

9.3. A empresa deverá elaborar e distribuir manuais de orientação ao produtor e implantar programas de conscientização sobre o sistema de coleta a granel, como preservar a qualidade do leite, como lavar e higienizar latões, mangueiras, equipamentos e utensílios na propriedade e a importância da manutenção da temperatura adequada do leite.

9.4. Manter as instalações da coleta coletiva de leite tipo $\mathrm{C}$ em perfeito estado de conservação, higiene e limpeza, responsabilizando-se tecnicamente pela sua operação.

10. DISPOSIÇÕES GERAIS

10.1. O produtor integrante do PCG será obrigado a destinar toda a sua produção para estabelecimento sob inspeção federal. O não cumprimento dessa exigência acarretará seu imediato afastamento do programa.

10.2. Para os produtores já integrantes do $P C G$, será obrigatório $o$ atendimento das presentes normas, nos prazos abaixo estabelecidos:

de imediato para o resfriamento adequado do leite; de 180 dias para a adequação das instalações. 
ANEXOE 
Avaliações a serem feitas para cada forma contratual:

\begin{tabular}{|c|c|c|c|c|}
\hline Categoria Contratual: & \multicolumn{2}{|l|}{ De: } & \multicolumn{2}{|l|}{ Para: } \\
\hline \multicolumn{5}{|l|}{ Objetivos da transação: } \\
\hline \multirow{2}{*}{ Natureza da transação } & \multicolumn{2}{|c|}{ Comentários } & \multicolumn{2}{|c|}{ Taxa de avaliação } \\
\hline & Antes & Depois & Antes & Depois \\
\hline \multicolumn{5}{|l|}{ Freqüência } \\
\hline \multicolumn{5}{|l|}{ Incerteza } \\
\hline \multicolumn{5}{|l|}{ Especificidade do ativo } \\
\hline \multicolumn{5}{|l|}{ Racionalidade limitada } \\
\hline \multicolumn{5}{|l|}{ Oportunismo } \\
\hline Governança & \multicolumn{4}{|c|}{ Comentários } \\
\hline \multicolumn{5}{|l|}{ Atual estrutura } \\
\hline \multicolumn{5}{|l|}{ Estrutura esperada } \\
\hline Implicações e observações & & & & \\
\hline
\end{tabular}

Fonte: Adaptado de Loader (1992). 


\section{REFERÊNCIAS BIBLIOGRÁFICAS}

ALCHIAN, A. Some Economics of Property. Santa Monica, Califórnia. 1961 (mimeo.)

ALCHIAN, A. \& DEMSETZ, H. Production, information costs, and economic organization. American Economic of Review, v. 62, p. 777-795. Dec. 1972.

ALMEIDA, A. A. P.; SILVA, P. H. F. Pagamento do leite pela qualidade: parâmetros e critérios. Revista Indústria de Laticínios,. p. 46-48, jul./ago. 1997.

ANUÁRIO MILKBIZZ. São Paulo, 1997.

ANUÁRIO MILKBIZZ. 1998. P. 34-46.

ARROW, K. J. Economic welfare and the allocation of resources of invention. National Economics Investigation Officer. Princeton University Press. 1962. p.609-625.

Uncertainty and the welfare economics of medical care. American Economic Review, v. 53, Dec. 1963. p. 941-973.

AZEVEDO, P. F. Integração vertical e barganha. São Paulo, 1996. 220 p. Tese (Doutorado). Faculdade de Economia e Administração da Universidade de São Paulo. 
CALEGÁRIO, C. L. L. As relaçōes contratuais no setor leiteiro no contexto do agribusiness. Lavras, UFLA. 1996. Dissertaçăo (Mestrado). 80 p.

CAMPOS, J. M. N. Vaca quer sombra e água fresca para dar leite. Revista DBO Rural. Maio 1998. p.34-38.

CHANDLER, A. C. Strategy and Structure. Cambridge, Mass.: MIT Press. 1962.

COASE, R. H. The problem of social cost. Journal of Law and Economics, v. 3, Oct. 1960. p.1-44.

FARINA, E. M. M. Q. Reflexões sobre desregulamentação e sistemas agroindustriais: A experiência brasileira. São Paulo, 1996a. 156 p. Tese (Livre Docência). Faculdade de Economia e Administração da Universidade de São Paulo.

Indústria de laticínios e o desenvolvimento da pecuária leiteira. Revista Balde Branco, no 375, p. 34-39, jan. 1996b.

FARINA, E.M.M.Q.; ZYLBERSZTAJN, D. Competitividade e organização das cadeias agro-industriais. Costa Rica, Relatório IICA, 63 p. 1994.

GIL, A.C. Técnicas de Pesquisa em Economia. Atlas, São Paulo, 195 p., 1995.

GOMES, S. T. Leite: economia e mercado definem novas tendências. Revista Balde Branco. no 376, p. 36-40, fev. 1996. 
HAMM, L. Why the world changed? Dairy Today Magazine, Nov/Dec 1997. p.16-17.

INTERNATIONAL DAIRY FEDERATION BULLETIN. Milk Payment Systems for Ex-farm milk, n. 305, 1995.

JANK, M. S. Leite: relação produtor/indústria trava avanço do setor. Revista Indústria de Laticínios, p. 5-9, mar./abr. 1997a.

Um furacão se aproxima. Revista Gado Holandês, no 464, p.68, jul. 1997b.

Competitividade do agribusiness brasileiro: Discussão teórica e evidências no sistema de carnes. 195 p., 1996. Tese (Doutorado). Faculdade de Economia e Administração da Universidade de São Paulo.

JANK, M.S.; GALAN, V.B. Itambé: O desafio das cooperativas no novo cenário do leite brasileiro. p. 1-31, 1997. Seminário Internacional PENSA de Agribusiness.

JANK, M.S.; GALAN, V.B. Competitividade do Sistema Agro-industrial do Leite. Documento base para discussão. Novembro de 1997. 26p.

JARDIM, S. Leite com qualidade: ação conjunta de indústria e produtor. Revista Balde Branco, n. 381, p. 9-12, jul. 1996.

LARANJA, L. F. Leite a granel: Modelo de estocagem e transporte. Revista Leite e Derivados, maio/junho 1998. p.16-22. 
Manejo, dieta e higiene: quando afetam a qualidade do leite.

Revista Balde Branco. n. 381, p. 30-34, jul. 1996.

Os minerais garantem a qualidade do leite. Revista Alimentação Animal, julho/agosto 1998. p. 8-9.

LOADER, R. Transaction cost and relationships in agri-food systems. Reading: Dept. of Agricultural Economics and Management. The University of Reading, p. 417-429, 1992.

MATTAR, F.N. Pesquisa de marketing. Atlas, São Paulo, 350 p, 1993.

MEIRELES, A. J. Revolução silenciosa e caos: o momento é de o setor lácteo brasileiro buscar a união. Revista Indústria de Laticínios. p. 68-73, set./out. 1997.

Avanço tecnológico do leite fluido: tipos, consumo e embalagens. Revista Balde Branco, n. 380, p. 34-40. jun. 1996.

NEVES,M.F. Sistema agro-industrial citrícola: um exemplo de quase-integração no agribusiness brasileiro. São Paulo, 1995. Dissertação (Mestrado). Faculdade de Economia e Administração da Universidade de São Paulo. $116 \mathrm{p}$.

RENTERO, N. Quando qualidade significa resfriamento e coleta a granel. Revista Balde Branco, n. 394, p. 46-49, agosto 1997. 
Nova Zelândia. Revista Balde Branco, p.20-26, junho 1998.

SANDREY, R.; REYNOLDS, R. Farming without subsidies: New Zealand's recent experience. $1990.347 p$.

SANTOS, J. A. dos. Leite: garantindo a qualidade, da fazenda à plataforma. Revista Indústria de Laticínios, n. 8, p. 12-17, mai. 1997.

Seminário As Cooperativas e a Produção de Leite Ano 2000. Organização das Cooperativas do Estado de Minas Gerais, 1995. 120 p.

SIFFERT FILHO, N.F. A economia dos custos de transação. Revista do BNDES, Rio de Janeiro, v. 2, n. 4, p. 103-128, dez. 1995.

SILVA, I.C.V.; REIS, R.P. Coleta a granel: passaporte para a modernização da cadeia do leite. Revista Indústria de Laticínios, p. 22-26., set./out. 1997.

Coleta de leite: qual a quilometragem viável economicamente? Revista Indústria de Laticínios, março/abril 1998. p.36-42.

SILVA, I.C.V.. Custos e otimização de rotas no transporte de leite a latão e a granel no primeiro percurso: um estudo de caso. Lavras - MG, 1999. Dissertação (Mestrado). Universidade Federal de Lavras, 120 p.

SOARES, M. G. Contractual relationship between dairy farmers and dairy companies and the milk collection system in the UK. Cirencester, Inglaterra. 1996. 112 p. (Relatório de Residência) 
SOARES, C. F. Racionalização das Linhas de Coleta de Leite: Uma Análise da Bacia Leiteira de Viçosa. Viçosa - UFV. 1988. Dissertação (Mestrado) $71 \mathrm{p}$.

SOBRINHO, F. F. et al. Coleta de leite a granel. Belo Horizonte: Fundação João Pinheiro, 1995. 96 p. (Monografia)

WILLIAMSON, O. E. The economic institutions of capitalism. New York, The Free Press, 1985. $449 \mathrm{p}$.

WILLIAMSON, O. E. Comparative economic organizations: The analysis of discrete structural alternatives. Administrative Science Quarterly., p. 136, 1991.

WILLIAMSON, O. E. The vertical integration of production: Market failure considerations. American Economic Review, v. 61, May. 1971. p. 112123.

WILLIAMSON, O. E Markets and hierarchies: some elementary considerations. American Economic Review, v. 63, May. 1973. p.316-325.

XAVIER, A. J. Da quantidade para a qualidade. Revista Balde Branco, agosto 1998. p. 48.

Modernização do setor produtivo de leite e derivados. Boletim do Leite, FEALQ/ESALQ/USP. 22 agosto 1999, 6 p.

ZYLBERSZTAJN, D. Estruturas de Governança e Coordenação do Agribusiness: Uma Aplicação da Nova Economia das Instituições. São 
Paulo, 1995. Tese (Livre Docência) - Faculdade de Economia e Administração da Universidade de São Paulo. 